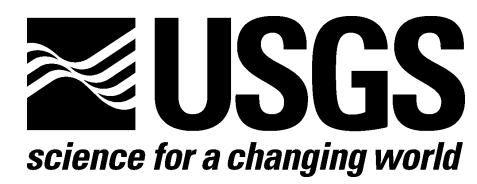

\title{
Volcanogenic Uranium Deposits: Geology, Geochemical Processes, and Criteria for Resource Assessment
}

By J. Thomas Nash

Open-File Report 2010-1001

U.S. Department of the Interior U.S. Geological Survey 


\section{U.S. Department of the Interior KEN SALAZAR, Secretary}

\section{U.S. Geological Survey Marcia K. McNutt, Director}

U.S. Geological Survey, Reston, Virginia: 2010

For product and ordering information:

World Wide Web: http://www.usgs.gov/pubprod

Telephone: 1-888-ASK-USGS

For more information on the USGS - the Federal source for science about the Earth, its natural and living resources, natural hazards, and the environment:

World Wide Web: http://www.usgs.gov

Telephone: 1-888-ASK-USGS

Suggested citation:

Nash, J. Thomas, 2010, Volcanogenic uranium deposits-Geology, geochemical processes, and criteria for resource assessment: U.S. Geological Survey Open-File Report 2010-1001, 99 p.

Any use of trade, product, or firm names is for descriptive purposes only and does not imply endorsement by the U.S. Government.

Although this report is in the public domain, permission must be secured from the individual copyright owners to reproduce any copyrighted material contained within this report. 


\section{Contents}

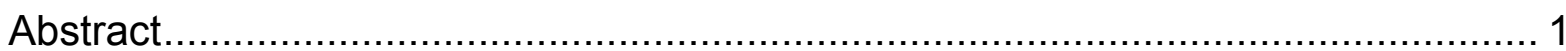

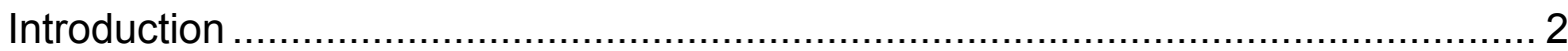

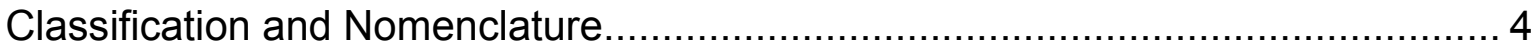

Known and Important Deposits: Descriptions and Comments ............................... 6

Largest in the World: Streltsovskoye, Russia............................................... 8

Even Larger "Volcanic” Deposit? Olympic Dam ............................................... 9

Pocos de Caldas, Brazil ........................................................................ 10

Dornot, Xiangshan, Chatkalo, and Other Districts of Asia................................ 12

Pena Blanca District, Mexico .................................................................. 12

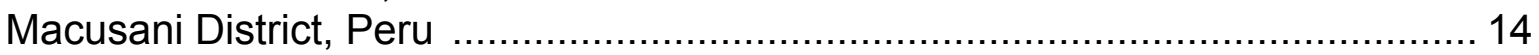

Lakeview District, Oregon ..................................................................... 14

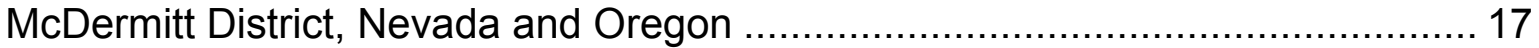

Aurora Prospect, McDermitt, Nevada-Oregon ........................................... 17

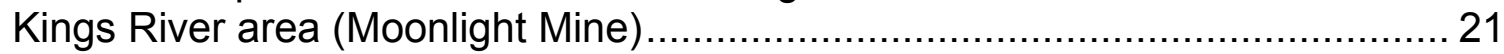

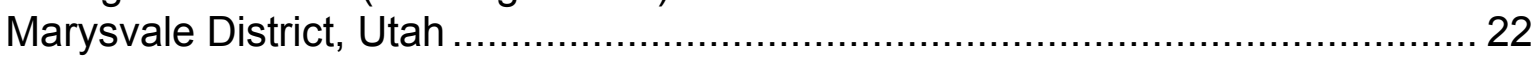

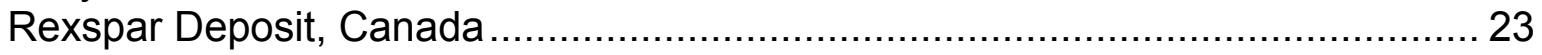

Georgetown-Townsville Uranium Field, Australia ......................................... 23

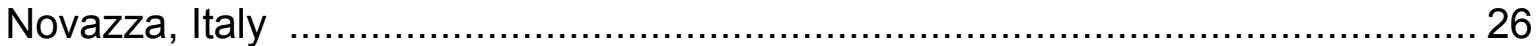

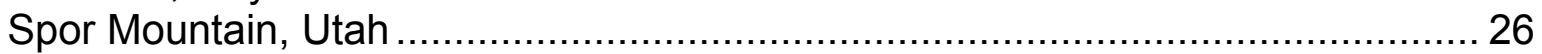

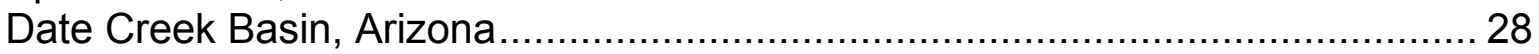

Lodeve District, France ........................................................................ 30

Virgin Valley District, Nevada .................................................................. 30

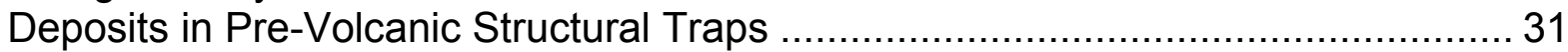

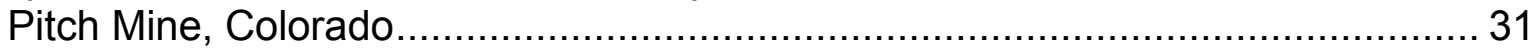

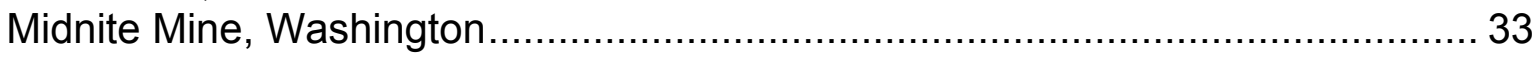

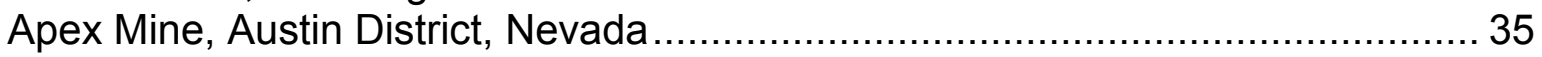

Arlit, Niger: Deposits in Volcaniclastic Sandstone ......................................... 36

Metamorphosed Volcanogenic Deposits...................................................... 36

Genesis of Uranium Deposits: Concepts for Source, Transport, and Deposition..... 37

Source Mechanisms and Concepts ............................................................. 37

Uranium in Magmas and Magmatic-Hydrothermal Fluids .............................. 37

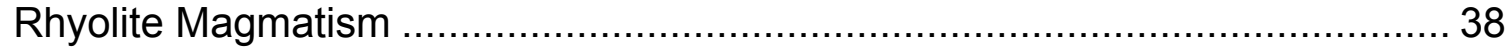

Petrochemistry of Uranium in Volcanic Rocks ......................................... 42

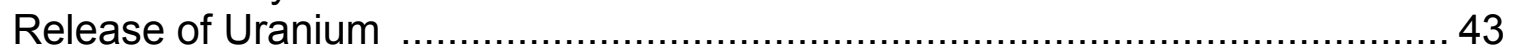

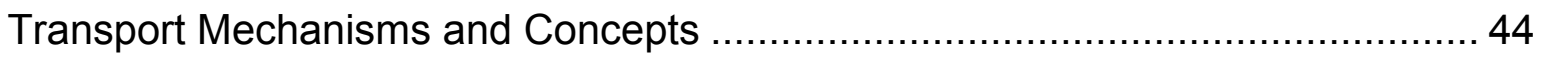

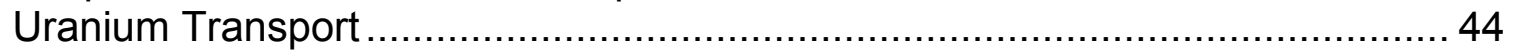

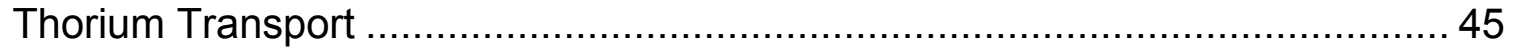

Hydrology of Volcanic Systems.................................................................. 46

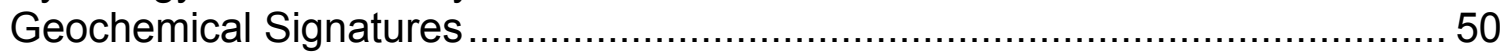

Uranium Deposition: Focused Flow, Traps, and Reductants ........................... 51

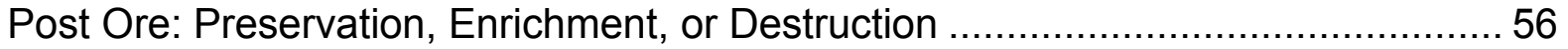

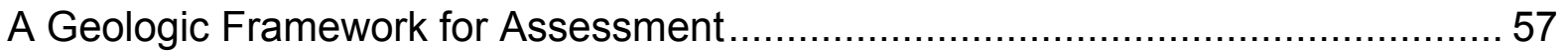

Assessment for Volcanogenic Uranium Deposits ............................................ 59

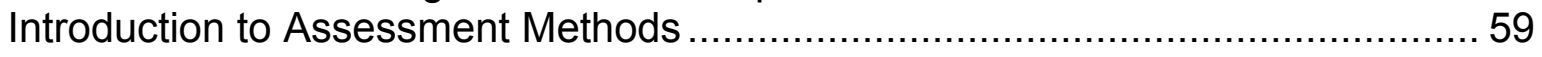


Assessment Step 1: Permissive Tract Delineation...........................................59

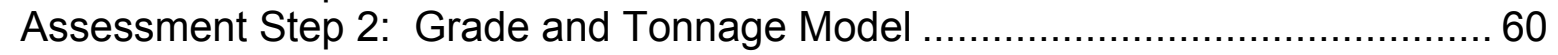

Assessment Step 3A: Estimates of Number of Undiscovered Deposits............... 61

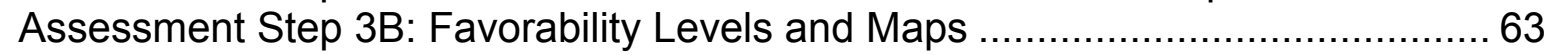

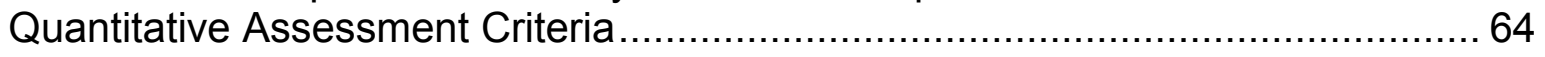

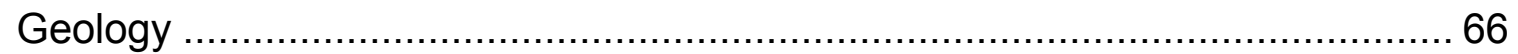

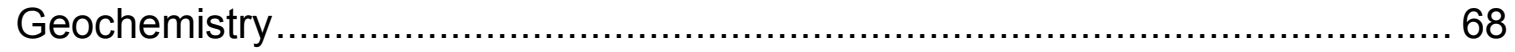

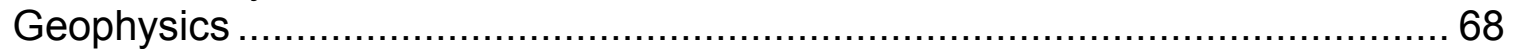

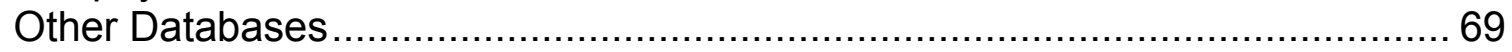

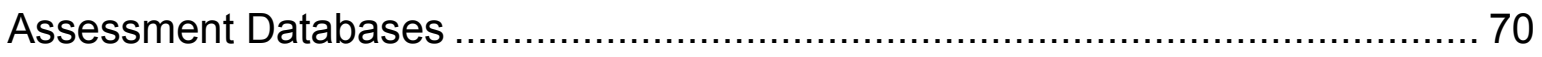

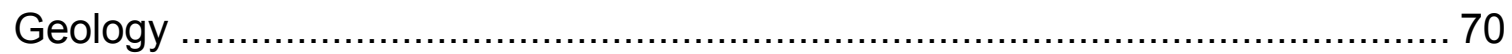

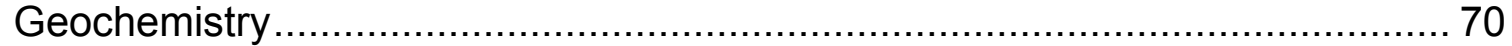

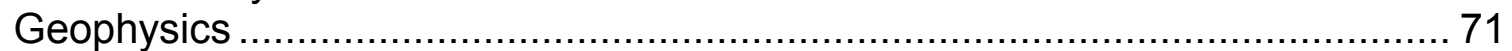

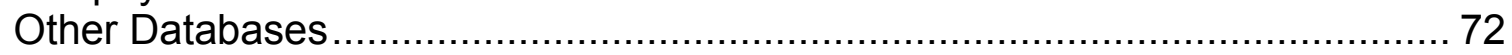

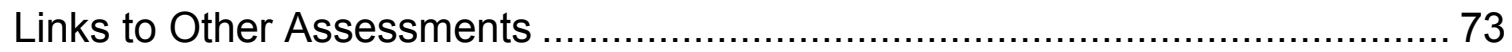

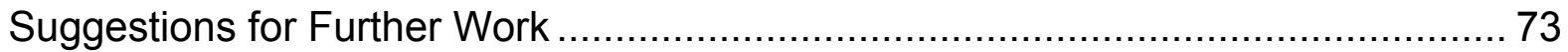

Comparison with Epithermal Processes ………...................................... 73

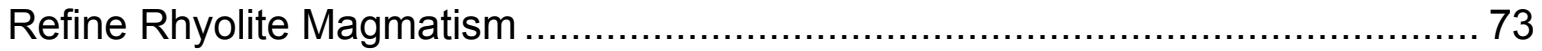

Evaluate Role of Sulfate-Rich Brines ........................................................... 74

Refine Sulfur Reduction Mechanisms ........................................................ 74

Hydrothermal Mobilization of Uranium in Volcaniclastic Strata ......................... 74

Refine Post-Ore Stability of Deposits ...................................................... 75

Refine Assessment Concepts and Practices ……........................................ 75

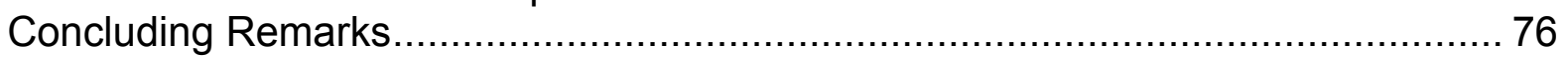

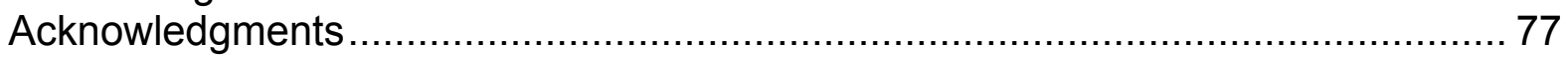

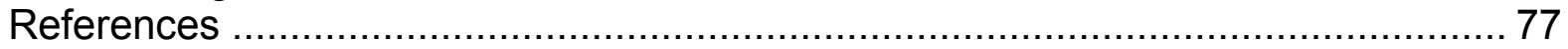

Appendix: Grade-Tonnage Relations Among Volcanogenic Uranium Deposits ...... 95

\section{Figures}

1. Location of volcanogenic uranium deposits, western U.S................................ 7

2. Geologic map of the Streltsovskoye caldera, Russia ........................................ 9

3. Conceptual diagram of the phreatic stage, Olympic Dam deposit....................... 10

4. Cross sections, Pena Blanca …............................................................. 13

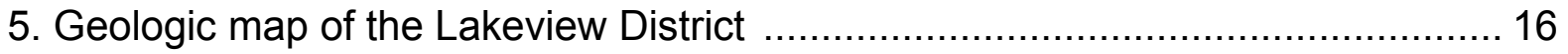

6. Geologic map and section of the Aurora deposit ............................................ 19

7. Cross section showing geology and ore lenses, Aurora deposit ....................... 20

8. Model of stages in the genesis of the Ben Lomond deposit .............................. 25

9. Simplified geologic map of the Spor Mountain area....................................... 27

10. Idealized map and cross section of the Date Creek area ................................2 29

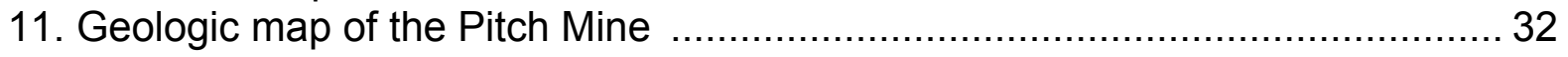

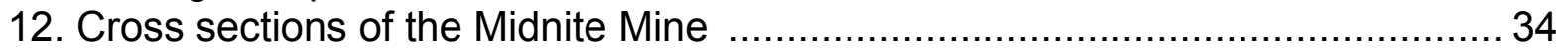

13. Cartoon describing bimodal basalt-rhyolite magmatism.................................... 39

14. Distribution of topaz rhyolites in the western United States ............................ 41

15. Model of convection, boiling, and mixing in the Creede District ........................ 47

16. Model of deep meteoric flow, northern Nevada basin .................................... 49 
17. Deep circulation in the San Juan and Silverton calderas, Colorado 55............. 49

18. Caldera structures and ore deposits in a resurgent caldera.............................52

19. Three stages in the mixing of stratified $\mathrm{Na}$ - and Ca-rich brines ........................ 54

20. Schematic cross section of an idealized volcanic system, showing postulated

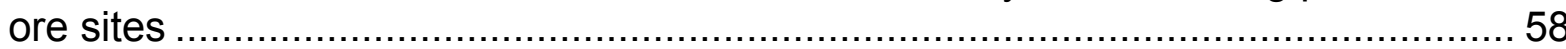

Appendix Figure 1-1. Tonnage of 32 volcanogenic uranium deposits................... 95

Appendix Figure 1-2. Grade of uranium in 32 volcanogenic deposits ..................... 96

Appendix Figure 1-3. Grade and tonnage of uranium in volcanogenic deposits ...... 97

\section{Tables}

1. Uranium resources in volcanic-type deposits .................................................... 4

2. Summary of assessment criteria for volcanogenic deposits .............................6 65

Appendix Table 1-1. Grade and tonnage data for 32 volcanogenic deposits........... 99 


\section{Units and Conversions}

Resources and reserves are reported here in metric units, even if the source reference used English units (pounds, short tons); the abbreviation $t$ is used for metric tonne. The oxide form, $\mathrm{U}_{3} \mathrm{O}_{8}$, is used as that is most common in the uranium industry; values are converted from $\mathrm{U}$ to $\mathrm{U}_{3} \mathrm{O}_{8}$ where necessary. Conversion factors and a useful calculator can be found at www.wise-uranium.org/cunit.html. Some handy conversions include:

1 million lbs. $\mathrm{U}_{3} \mathrm{O}_{8}$

1 wt percent $\mathrm{U}_{3} \mathrm{O}_{8}$

1 unit $\mathrm{U}_{3} \mathrm{O}_{8}$
500 short tons $\mathrm{U}_{3} \mathrm{O}_{8}$ or 453.6 tonnes $\mathrm{U}_{3} \mathrm{O}_{8}$ $10,000 \mathrm{ppm}_{3} \mathrm{O}_{8} \quad$ or $20 \mathrm{lbs} /$ short ton $0.848 \mathrm{U}$ 


\title{
Volcanogenic Uranium Deposits: Geology, Geochemical Processes, and Criteria for Resource Assessment
}

\author{
By J. Thomas Nash
}

\section{Abstract}

Felsic volcanic rocks have long been considered a primary source of uranium for many kinds of uranium deposits, but volcanogenic uranium deposits themselves have generally not been important resources. Until the past few years, resource summaries for the United States or the world generally include volcanogenic in the broad category of "other deposits" because they comprised less than 0.5 percent of past production or estimated resources. Exploration in the United States from the 1940s through 1982 discovered hundreds of prospects in volcanic rocks, of which fewer than 20 had some recorded production. Intensive exploration in the late 1970s found some large deposits, but low grades (less than about 0.10 percent $\mathrm{U}_{3} \mathrm{O}_{8}$ ) discouraged economic development. A few deposits in the world, drilled in the 1980s and 1990s, are now known to contain large resources $\left(>20,000\right.$ tonnes $\left.\mathrm{U}_{3} \mathrm{O}_{8}\right)$. However, research on ore-forming processes and exploration for volcanogenic deposits has lagged behind other kinds of uranium deposits and has not utilized advances in understanding of geology, geochemistry, and paleohydrology of ore deposits in general and epithermal deposits in particular. This review outlines new ways to explore and assess for volcanogenic deposits, using new concepts of convection, fluid mixing, and high heat flow to mobilize uranium from volcanic source rocks and form deposits that are postulated to be large. Much can also be learned from studies of epithermal metal deposits, such as the important roles of extensional tectonics, bimodal volcanism, and fracture-flow systems related to resurgent calderas.

Regional resource assessment is helped by genetic concepts, but hampered by limited information on frontier areas and undiscovered districts. Diagnostic data used to define ore deposit genesis, such as stable isotopic data, are rarely available for frontier areas. A volcanic environment classification, with three classes (proximal, distal, and prevolcanic structures), permits use of geologic features on 1:500,000 to 1:100,000 scale maps. Geochemical databases for volcanic rocks are postulated to be more effective than databases for stream sediments or surface radioactivity, both of which tend to be inconsistent because of variable leaching of uranium from soils. Based on empirical associations, spatial associations with areas of wet paleoclimate, adjacent oil and gas fields, or evaporite beds are deemed positive. Most difficult to estimate is the location of depositional traps and reduction zones, in part because they are mere points at regional scale.

${ }^{1}$ GXPLOR4U, Las Vegas, NM 87701 gxplor4u@yahoo.com 
Grade and tonnage data are reviewed and discussed for 32 deposits in the world. Experience of mining engineers and geologists in Asia suggests that tonnages could be higher than presently known in the Western Hemisphere. Geological analysis, and new data from Asia, suggest a typical or median deposit tonnage of about 5,000 tonnes $\mathrm{U}_{3} \mathrm{O}_{8}$, and an optimistic forecast of discoveries in the range of 5,000 to 20,000 tonnes $\mathrm{U}_{3} \mathrm{O}_{8}$. The likely grade of undiscovered deposits could be about 0.15 percent $\mathrm{U}_{3} \mathrm{O}_{8}$, based on both western and eastern examples. Volcanic terrane is under-explored, relative to other kinds of uranium deposits, and is considered a favorable frontier area for new discoveries.

\section{Introduction}

Volcanic rocks are arguably the source of uranium for many types of uranium deposits. Nonetheless, volcanogenic deposits in the United States account for less than 0.5 percent of total production and have the reputation of having too low a grade for economic significance. Volcanic rocks are a major component of the geology of the western United States, but few recognized volcanogenic uranium deposits have resources or reserves that are economically viable. Known volcanogenic prospects were reexamined in the recent (2005-2008) exploration boom yet the press reports few applications for permits for new mines or mills. The large resource at the Anderson Mine, Arizona, has been drill-defined for nearly 30 years, but applications for mine and mill permits were apparently only in the preliminary stages as of 2008 . What is the potential for discovery of new deposits that could be significant uranium producers in the United States?

In this report I will review published literature on volcanic-associated uranium deposits in the United States, and known deposits elsewhere, and will add my interpretations. This review will be at many scales, from microscopic to regional, and the perspective will be both descriptive (empirical) and genetic. As in a past review (Nash and others, 1981), the emphasis will be on important deposits ${ }^{2}$, meaning deposits with the potential to contain more than $500 \mathrm{~kg}$ (roughly 1 million pounds) $\mathrm{U}_{3} \mathrm{O}_{8}$ at economically viable grades. At first glance, known volcanogenic deposits seem to be one of a kind and have few features in common, so in this review I will attempt to identify common features and common processes that might be integrated into a new, conceptual model. This model will be incomplete because not all parts and processes postulated in the model have been defined. Grade and tonnage information from known deposits will be extrapolated to estimate potential resources in undiscovered deposits. The derived model should be considered distinct from previously published models (for example, Bagby, 1986) as the new model reflects recent $U$ deposit discoveries. The new model is designed to assist uranium resource assessment by the Mineral Resources Program of the U.S. Geological Survey, but is applicable to exploration, also.

2 "Important" is difficult and subjective to define. In 1981, Nash, Granger, and Adams (Nash and others, 1981) used the term "important" at the suggestion of Sam Adams, who 
knew the significance of large deposits as an exploration manager in the private sector. The choice of $500 \mathrm{~kg}$, or roughly 1 million lbs, is a fairly high requirement for hardrock U deposits in the United States; this is far below the definition of Nash and others (1981) in which "important" is associated with deposits holding "the major part of known world reserves." The definition used in this report is roughly mid-range for sandstone-type deposits, noting that most of their resource statistics (Chenoweth, 1991) are for districts not single deposits. "Viable" also is vague, as average grade for economic mining depends on many non-geologic factors; in 2008 it was roughly 0.1 percent $\mathrm{U}_{3} \mathrm{O}_{8}$ and somewhat lower for deposits amenable to in-situ solution mining. This is a general estimate, taken largely from recent press releases from mining companies.

This report builds upon the previous volcanogenic uranium deposit model by Bagby (1986), but the goals and format of this report differ from that of Bagby (1986). The two main goals of this report are 1) review what is understood, or not, about the known deposits, and to discuss, and speculate on, processes of ore formation in order to improve regional resource assessment, and 2) develop a framework for assessment that is consistent with genetic processes but based on regional-scale spatial databases that are most likely to be available for frontier areas and undiscovered districts. Regional scale (about 1:500,000) is an important caveat; approaches at district scale $(1: 24,000)$ may be different for many criteria.

After writing this report in 2008, I came across a helpful database on world uranium deposits (as of 2005-2007) that is maintained by the International Atomic Energy Agency (IAEA, 2008) (http://www-nfcis.iaea.org). The database includes information on parts of the world not normally reviewed by Western scientists. The new database suggests that volcanic deposits are much more common, and larger in tonnage, than evident in the Western Hemisphere (table 1). There are large resources in volcanic deposits in China, Kazakhstan, Mongolia, and the Russian Federation (beyond those of Streltsovskoye described here). Helpful reviews of the deposits in Asia are provided by Cuney and Kyser (2009), who note that geochemical studies are notably lacking. A compilation by Cuney (2009) that includes past production, reasonably assured, and inferred resources comes up with even larger total world resources for volcanic-type deposits, amounting to 5.7 percent of total world $\mathrm{U}$ resources. Attempts to find more information on the geology of these important, newly-discovered deposits was not successful as of April, 2009. 


\begin{tabular}{|lr|}
\hline \multicolumn{1}{|c|}{ Country } & \multicolumn{2}{c|}{$\begin{array}{l}\text { Uranium } \\
\text { Resources in } \\
\text { tones } \mathrm{U}_{3} \mathrm{O}_{8}\end{array}$} \\
Australia & 10,980 \\
Brazil & 26,763 \\
Bulgaria & 4,244 \\
Canada & 2,700 \\
China & 11,790 \\
Italy & 5,659 \\
Kazakhstan & 19,571 \\
Mexico & 5,288 \\
Mongolia & 59,409 \\
Russian Federation & 178,931 \\
United States of America & 37,139 \\
\hline
\end{tabular}

Table 1. Uranium resources in volcanic-type deposits, as defined and compiled by IAEA (2008). Resources reported in tonnes $\mathrm{U}_{3} \mathrm{O}_{8}$.

\section{Classification and Nomenclature}

For purposes of exploration and resource assessment, existing classifications or models of volcanogenic $\mathrm{U}$ deposits are too specific and focus on features such as calderas. Also, the models tend to be genetic and include terms like "hydrothermal vein," but this approach is not helpful in regional mineral resource assessment. The classification outlined by Goodell (1981b) is based on the volcanic environment--features that might be discerned from a geologic map. That framework has been expanded here and includes additional parts of an idealized volcanic system. In this report, the focus will be on three environments - proximal and distal to a volcanic center, and structures that pre-date volcanic activity. The proximal environment includes a caldera, intracaldera facies, caldera-bounding faults, and commonly has dikes, plugs, and sub-volcanic stocks. The distal environment is characterized by flows, more air-fall tuffs, less welding, and may have lacustrine basins filled by volcaniclastic rocks. Pre-volcanic structures including faults, fractures, and breccia can contain deposits related to overlying volcanics or the volcanic hydrothermal regime. This is similar in concept to the newly proposed sub-class of sandstone-type deposits, "tectonolithologic," that is separated for the important structural and hydrologic influence of faults (Cuney and Kyser, 2009).

Locations of known deposits and districts in the western United States are shown on figure 1. 
Although most terms are widely used by geologists, some take on special connotations in economic geology and resource assessment. Definitions adopted for this report follow:

Volcanogenic will be used as a simplification of other terms such as "volcanic associated." This term will be used for the spatial association, and does not presume a genetic relationship. For example, a volcanogenic deposit must be in or near volcanic rocks, but could form significantly later than those volcanic rocks. The term volcanogenic, as defined here, is intended to be inclusive, but it does not extend to sandstones containing moderate to small amounts of volcanic clasts. Volcaniclastic rocks with more than about 50 percent volcanic material are included. Shallow intrusive bodies are included if they are part of the volcanic (extrusive) system. The intent is to exclude shallow intrusive bodies of the porphyry type (for example, Climax Mo type) because the amount of magmatic volatile elements in the latter are substantial and important for metal transport, but thought to be nil or minor for the uranium systems described here.

Distal and proximal will be used to specify the relative spatial position in the volcanic system. Other terms could be used, and some geologists may find this an oversimplification. Proximal, as the word normally is used, implies a close distance to the volcanic center; here it will include intracaldera facies. Distal will be used to specify environments that are distant from the volcanic center, such as outflow facies and airfall or lacustrine tuffs. As used here, distal has a connotation of low temperatures in rocks and groundwaters (that is, little or no magmatic heat).

Magmatic will be used in a specific sense, in the manner of isotope geochemists, for an element or component related to the sub-volcanic magma chamber and its very high temperatures. For the systems discussed here, the elements F, Mo, and Th are most likely to be mobilized (uniquely) in magmatic fluids. Meteoric will be used for components, especially water, in the near-surface environment but can include deeply circulating groundwaters. I assume that by volume most water in volcanic systems is meteoric, although there may be exceptions. Supergene will be used in cases that are known or suspected to be close to the surface, with a connotation of oxidized state. Typical supergene processes are oxidation of sulfide minerals, acid alteration that leaches feldspars and creates Al-silicates such as kaolinite, vertical zonation relative to a former water table, and replacement of black $\mathrm{U}^{+4}$ minerals by yellow $\mathrm{U}^{+6}$ phases such as autunite.

Metamorphosed volcanogenic uranium deposits are briefly treated here, even though some (Gandhi, 1978; Curtis, 1981) recognize syn-volcanic features in metamorphic terrains of northern and eastern Canada (for example, Baker Lake Basin and Makkovik Fold Belt).

Terms used for resource assessment may be unfamiliar to persons outside the U.S. Geological Survey. Unlike definitions used by the private sector or by the International Atomic Energy Agency (IAEA), cost or economic parameters such as " $\$ 80$ per kg" are not used here. Economic potential is implied but not specified. A mineral deposit is a 
"concentration of minerals of sufficient size and grade that it might, under the most favorable of circumstances, have economic potential" (Cox and Singer, 1986). Other situations having lesser concentration or size, or not amenable to mineral processing, are considered occurrences or prospects. Implicit in the term "concentration" is some indication of geologic or geochemical processes that produced the noteworthy enrichment.

An undiscovered deposit is a special case of a deposit that may exist in a geologically defined area but is incompletely defined by exposure or drilling. The definition of undiscovered deposit used in the past (Ludington and Cox, 1996): "An incompletely explored mineral occurrence or prospect that could have sufficient size and grade to be classed as a deposit can be considered to be an undiscovered deposit" poses questions. For purposes of resource assessment I suggest a revised definition of undiscovered deposit: An incompletely exposed mineral deposit for which there is sufficient geological and geochemical information to postulate it being similar to known deposits of the class, and related grade and tonnage characteristics, and for which there is reasonable geologic or geochemical indications that ore-forming processes have operated. If there is insufficient evidence for ore-forming processes, such as rock alteration or viable reactants that could cause mineral concentration, the locality should be classified as a mineral occurrence.

\section{Known Important Deposits: Descriptions and Comments}

Geology and attributes of known important volcanogenic uranium deposits illustrate similarities and differences within this relatively small number of welldescribed deposits. Many of the larger explored and mined volcanogenic deposits seem to be one of a kind. Based on the experience of the U.S. Geological Survey it is not wise to build an assessment model around a single example. Yet, these examples provide useful and important insights to ore genesis and exploration guides. The goal of examining as many examples as possible is to generate a framework that is inclusive of the attributes, processes, and settings of individual deposits. 


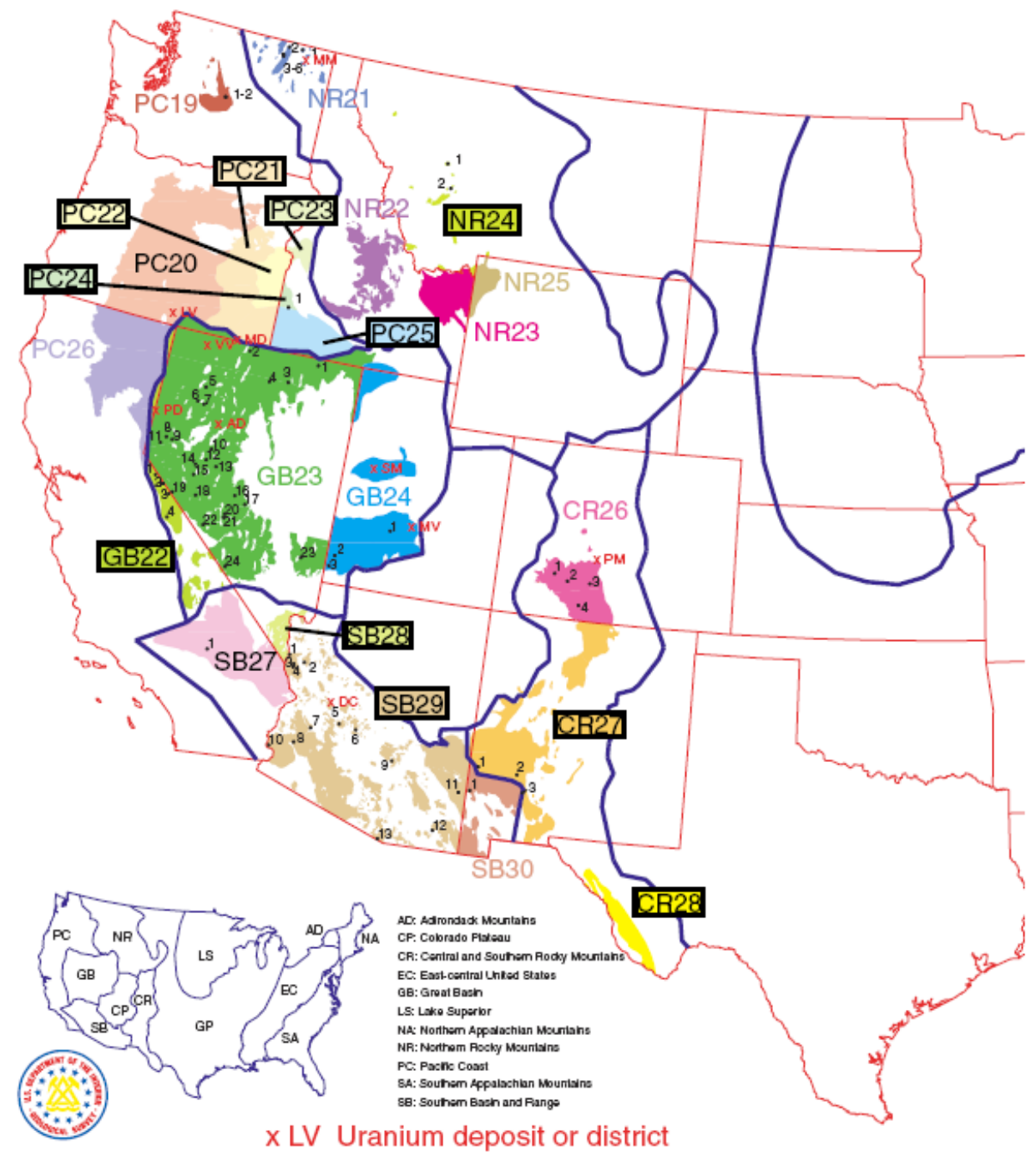

Figure 1. Location of volcanogenic uranium deposits in the western United States. The base map shows Tertiary felsic to intermediate volcanic rocks, taken from the 1996 National Mineral Resource Assessment (Ludington and Cox, 1996); these were the permissive tracts for epithermal vein deposits (known deposits shown in black). There were no permissive tracts in the eastern United States. Tracts (in color) and deposit numbers in black are explained by Ludington and Cox (1996). Uranium deposits and districts shown by red X: AD, Austin District; DC, Date Creek District; LV, Lakeview District; MM, Midnite Mine; MV, Marysvale District; PM, Pitch Mine; PD, Petersen Mountain District; SM, Spor Mountain District; VV, Virgin Valley District. 


\section{Largest in the World: Streltsovskoye, Russia}

Uranium deposits associated with the Jurassic Streltsovskoye caldera (also spelled Streltsovka) in Transbaikalia, Russia (fig. 2), are thought to be the largest volcanogenic resource in the world at 280,000 $\mathrm{t} \mathrm{U}\left(330,000 \mathrm{t} \mathrm{U}_{3} \mathrm{O}_{8}\right)$ (Chabiron and others, 2003; IAEA, 2008, Cuney and Kyser, 2009). There are many lessons to be learned from these deposits: perhaps most important is the potential for very large amounts of contained uranium at economic grades. The resource estimate is for ores grading more than 0.2 percent $\mathrm{U}\left(0.235\right.$ percent $\left.\mathrm{U}_{3} \mathrm{O}_{8}\right)$ which are in the lowest cost category in the IAEA classification (IAEA, 2008). This huge district resource comes from 18 deposits (fig. 3); an additional 18,400 $\mathrm{t} \mathrm{U}_{3} \mathrm{O}_{8}$ is contained in lower grade (higher cost) deposits. Two mined deposits contain reserves plus resources greater than 41,200 $t$ and 70,700 $t \mathrm{U}_{3} \mathrm{O}_{8}$. Sixteen deposits are in intracaldera units. Drilling to a depth of 2,700 $\mathrm{m}$ in the caldera and detailed geologic-geochemical studies provide a wealth of information. The individual deposits are only briefly described as subvertical veins and lateral expansions along permeable clastic and tuff horizons (Chabiron and others, 2003). [Note added in proof: the deposits are described quite well by Ischukova, 1997, in an obscure publication]. Following three stages of alteration (albite, illite, and chlorite, with quartz veins), uranium was deposited as pitchblende with quartz, fluorite, and molybdenite; brannerite (U-Ti-oxide) occurs in deep extensions of veins. Phase relations of the preuranium stage suggest a temperature of $300^{\circ} \mathrm{C}$. Uranium was deposited later, at lower temperatures, "when the hydrothermal convection system above the magma chamber...was invaded by oxidized meteoric fluids" (Chabiron and others, 2003). Recent data and additional interpretations (some in Russian literature) are reviewed by Cuney and Kyser (2009). Several kinds of U-Pb and K-Ar dates on uranium and alteration minerals suggest a thermal event of long duration but not more than $3 \mathrm{Ma}$.

The caldera was formed by eruption of mildly peralkaline rhyolite magma that was rich in F (1.4 to $2.7 \mathrm{wt}$ percent) and $\mathrm{U}$ (15-23 ppm) (Chabiron and others, 2001). Extensive alteration leached $U$ that was predominantly in glassy matrix. But this source of U, large as it is, was not enough to explain the discovered resources. The research of Chabiron and others (2003) finds that altered basement rocks and subalkaline granite (about $300 \mathrm{Ma}$ ) also were rich in U. The U-bearing phases in granitic basement (thorite, allanite/monazite, zircon, apatite, and possibly uraninite) were metamict after 15-200 Ma and available for leaching by hydrothermal fluids associated during caldera collapse. The huge resources in the Streltsovskoye caldera appear to reflect the juxtaposition of two fertile uranium sources: glassy peralkaline rhyolite and metamict accessory minerals in subalkaline granite (Chabiron and others, 2003). Hydrothermal fluids appear to have leached large volumes of U-rich rock and transported $U$ to the site of deposition; magmatic fluids from the perakaline sub-volcanic magma probably were a negligible contributor because calculations show that the Cl-rich, $\mathrm{H}_{2} \mathrm{O}$-poor fluid would carry very little U. Instead, U was fractionated into the melt phase. 


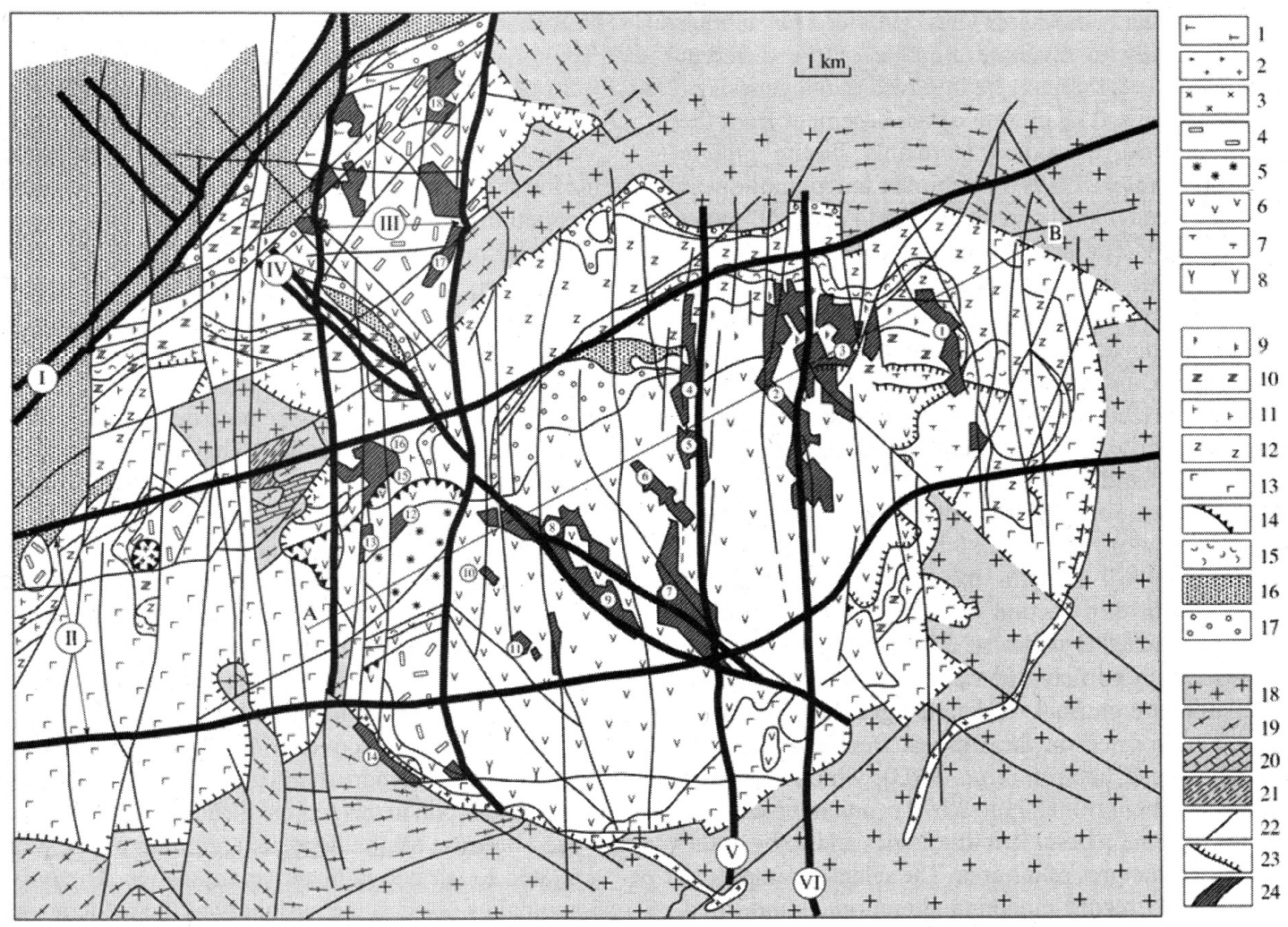

Fig. 7.13. Geologic map of the Streltsovskoye caldera with the location of the U ore deposits. A SW-NE cross section is given below. Major tectonic structures: I = Urulunghuyevskaya shear zone, II, = Argunskaya shear zone, III = Meridional fault zone, IV = Malo-Tulukuyevskaya fault, $\mathrm{V}=$ central fault, $\mathrm{VI}=$ Streltsovskoye fault. Uranium ore deposits: 1 : Shironoskoye, 2: Streltsovskoye, 3: Antei, 4: Oktabraskoye, 5: Luchistokoye, 6: Martoskoye, 7: Malo-Tulukuyevskoye, 8: Tulukuyevskoye, 9: Yubilenoye, 10: Vesenneye, 11: Novogodneye, 12: Pyatletneye, 13: KranyKamen, 14: Yugo-Zapadnoye, 15: Zherlovoye, 16: Argunskoye, 17: Berzrechnoye, 18: Dal'nee. Legend of the figure: Turginskaya Suite (Cretaceous): 1: basalt, 2: dikes and subvolcanic bodies of finely porphyritic latite, $3:$ syenite, syenite-porphyry, granosyenite-porphyry, 4: upper sheet of liparite, 5: spherulitic liparite, 6: massive and fluidal rhyolite and tuff, 7: andesite, 8:lower sheet of fine-fluidal spherulitic and glassy liparite, Priargunskaya Suite (Jurassic): 9: upper sheet of basalt and andesitic basalt, 10: upper trachyte sheet, 11: medium sheet of basalt, 12: lower sheet of trachydacite, 13: lower sheet of andesitic basalt, 14: volcanic centers, 15: tuff, 16: sandstone, 17: conglomerate, basement: 18: Variscan granite, 19: Caledonian orthogneiss, 20: marble, 21: metasedimentary gneiss, 22 : steeply dipping faults, 23 : caldera ring structure, $24: \mathrm{U}$ ore deposits projected to the surface.

Figure 2. Geologic map of the Streltsovskoye caldera and 18 uranium deposits. (fig. 7.13 of Cuney and Kyser, 2009; OMineralogical Association of Canada).

\section{Even larger "volcanic" deposit? Olympic Dam}

The largest uranium deposit in the world, the Olympic Dam deposit in Australia, might be considered to be volcanogenic in structural setting (fig. 3). Some authors use the term "subvolcanic" for the Olympic Dam environment (for example, Haynes and others, 1995). The amount of by-product uranium is staggering: the orebody ( $>7$ billion tonnes) contains measured and indicated resources (as of 2007) of 2,250,000 t $\mathrm{U}_{3} \mathrm{O}_{8}$ at 0.025 percent $\mathrm{U}_{3} \mathrm{O}_{8}$ (BHP Billiton, 2008). The details of the deposit and the debates of its origin are too complex for review here, but this large $\mathrm{U}$ deposit shares genetic characteristics with known volcanogenic deposits. Specifically, there is evidence that 
large volumes of heated meteoric water, oxidized, leached and transported U into structural traps, where chemical reduction of uranium deposited ore minerals. Mixing reactions are documented by detailed stable isotope and fluid-inclusion studies (Davidson and others, 2007).

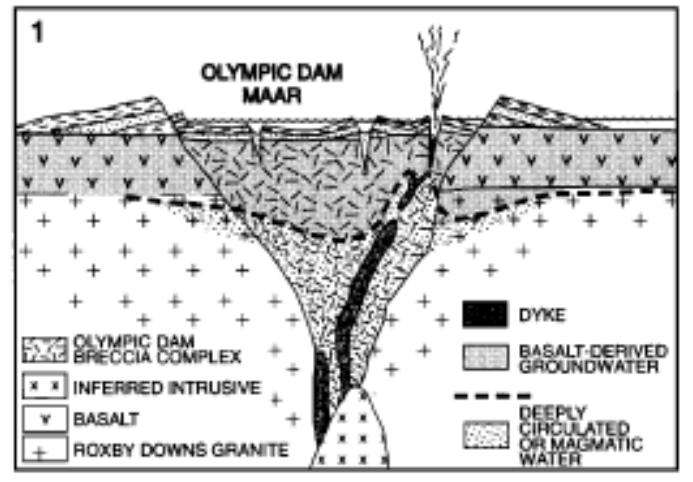

Figure 3. Conceptual diagram of the phreatic early stage of the Olympic Dam deposit, Australia. (fig. 11-1 of Haynes and others, 1995; @Society of Economic Geologists).

\section{Pocos de Caldas, Brazil}

The large $\left(1,000 \mathrm{~km}^{2}\right)$ alkaline intrusive complex at Pocos de Caldas is famous for its unusual enrichment in zirconium minerals that contain uranium, but in 1977 a different kind of deposit was found that contained uraninite and other U minerals that are amenable to milling (Loureiro and Dos Santos, 1988). ${ }^{3}$ The complex consists of a variety of alkaline intrusive and extrusive rock types and many internal structures, both circular and linear. The sequence of geologic events is thought to fit the Smith and Bailey (1968) model for resurgent calderas. The structural package, rock compositions, and ore minerals resemble the famous alkaline complexes of Kvanjfeld, Greenland and Pilansburg, South Africa, except that Pocos de Caldas has more rocks formed by explosive volcanism (tuffs and breccias) and more $U$ as uraninite, and it is richer in Mo, and $\mathrm{Zr}$ (perhaps reflecting the greater availability of $\mathrm{F}$ in ore-forming fluids). Note that some experts (for example, Cuney and Kyser, 2009) classify these deposits as magmatic, to emphasize that stage of the sequence of processes.

${ }^{3}$ The U-Th-REE deposits at Pocos de Caldas are described in remarkably different terms by Loureiro and Dos Santos (1988), who worked for NUCLEBRAS, and then by an international team of geochemists that used the ores as analogs for a nuclear waste depository (Waber and others, 1992; Cathles and Shea, 1992). The geology and setting of deposits is well described by NUCLEBRAS geologists (Loureiro and Dos Santos, 1988), but a much more detailed description of the mineralization sequence, alteration, and geochemistry is given by the researchers. 
The largest U deposit, at the Osamu Utsumi Mine, formed in five orebodies, A to E, that could be called separate deposits. The earliest U stage was associated with "high energy" fluidized dikes called "tufficitic breccia." The breccias are also described as "volcanic breccia pipes," about $80 \mathrm{~m}$ in diameter (Waber and others, 1992). The primary stage of U-Th mineralization, and several subsequent stages, were focused inside these breccia pipes. The ore zones are described as 900 to $1200 \mathrm{~m}$ long, 400 to $530 \mathrm{~m}$ wide, and continuous to at least $250 \mathrm{~m}$ depth. The reasonably assured and estimated resources for the Osamu Utsumi deposit (five zones) are about $21,800 \mathrm{t}$ at 0.085 percent $\mathrm{U}_{3} \mathrm{O}_{8}$ (Loureiro and Dos Santos, 1988). An adjacent prospect contains a substantial tonnage of $\mathrm{U}$ that is refractory in milling tests; much of the $\mathrm{U}$ resides in zircon. The substantial resources of Mo and $\mathrm{Zr}$ have not been evaluated as by-products.

Detailed geochemical studies were undertaken by Waber, Cathles, and other researchers in the analog nuclear waste repository studies, and their studies focused on five core holes that may not provide representative samples of the complex ore deposits and host rocks. The breccia pipes were altered several times; during an early stage U-ThREE were introduced and disseminated through the pipes. Concentrations are difficult to discern, but several tables of analyses suggest a range of about 40 to $180 \mathrm{ppm} \mathrm{U}$, and a figure of $40 \mathrm{ppm} U$ was used to characterize the primary protore in heat flow analyses (Cathles and Shea, 1992). Hydrothermal alteration of the breccia pipes began with an early potassic stage that added pyrite and $\mathrm{K}$-feldspar and leached $\mathrm{Ca}-\mathrm{Na}-\mathrm{Mg}$. Fluid inclusions for the potassic stage have homogenization temperatures of $250-260^{\circ} \mathrm{C}$ and 7-9 wt percent $\mathrm{KCl}$ equivalent (Waber and others, 1992). The next stage of hydrothermal alteration deposited fluorite, zircon, molybdenite, siderite, REE phases such as monazite and bastaesite, $\mathrm{U}$ and Th; fluid inclusions have homogenization temperatures of $210^{\circ} \mathrm{C}$, $\mathrm{KCl}$ daughter minerals ( $>40 \mathrm{wt}$ percent $\mathrm{KCl}$ equivalent), and are associated with gas-rich inclusions that indicate boiling. Thorium concentrations during this stage exceed uranium. Finally, supergene processes redistributed and enriched uranium, creating pods of botryoidal pitchblende that have high grades. Porosity created during early potassic alteration facilitated the movement of oxidizing meteoric water throughout the breccia pipes.

The thermal-fluid flow model for the Osamu Utsumi breccia pipe, based on extensive petrologic, chemical, and stable isotopic data (Cathles and Shea, 1992) provides a general model of hydrothermal alteration and mineralization in calderas and underlying stocks. Key parameters used in the model were the large chemical losses and gains in breccia pipes during hydrothermal emplacement of $40 \mathrm{ppm} \mathrm{U}$, and the solubility of silica. Calculations suggest that boiling, high salinity fluids convected through and around the breccia pipes. Heat required for fluid convection requires an underlying intrusion about $6 \mathrm{~km}$ in diameter and $10 \mathrm{~km}$ deep. These calculations, based on a strong database of petrochemical data, are in good agreement with geologic models of calderas (for example, Sillitoe and Bonham, 1984), but the convection model is more explicit than most geology-based models of volcanogenic uranium deposits. In the second part of their paper, Cathles and Shea (1992) calculate the geothermal implications of the body of protore $(40 \mathrm{ppm})$, postulating that it would have raised temperatures to about $200^{\circ} \mathrm{C}$; 
boiling occured near the ground surface, and convection of water occurred through a volume of approximately $10 \times 10 \times 10 \mathrm{~km}$. This model supports the concept of others (for example, Fehn and others, 1978; Plant and others, 1999) that high heat production intrusions can drive meteoric water circulation that can leach and redistribute uranium long after the magmatic (eruptive) stage.

\section{Dornot, Xiangshan, Chatkalo, and other districts of Asia}

Caldera-like structures of Mongolia, China, Uzbekistan, and Kazakhstan are known to contain large resources of uranium (IAEA, 2008; Cuney and Kyser, 2009). Deposits are reported to contain 10,000 to more than $20,000 \mathrm{t} \mathrm{U}_{3} \mathrm{O}_{8}$, but there is very little literature in English, and few geochemical and ore genesis studies have been undertaken. The volcanic systems are said to be of Cretaceous age, in major structural zones in granitic cratons. The deposits are said to be generally similar to those of the Streltsovskoye caldera. The U-Mo-F-Th association in many of the Asian deposits suggests "high temperature processes, possibly in relation with magmatic fluids exsolved from the melts" (Cuney and Kyser, 2009, p. 144).

\section{Pena Blanca District, Mexico}

In the late 1970s the newly discovered uranium deposits of Pena Blanca, south of Texas, were the subject of much speculation as an environment worth seeking in the United States. Numerous anomalies and prospects, and three deposits, were found in association with the widespread $44 \mathrm{Ma}$ Eocene Nopal Formation that is chiefly rhyolitic crystal-lithic tuff (Goodell, 1981a). Three deposits (Nopal I, Margaritas, and Puerto III), were thoroughly drilled and explored by test underground and surface excavations. Production started just prior to the collapse of the uranium market in 1982. The deposits contain a variety of yellow, hexavalent $U$ minerals, but some uraninite is found at Nopal I. Studies by Goodell (1981a) and his students found a trace element suite similar to epithermal ore deposits but inconsistent associations with $U$. They propose that uranium was leached from volcanic glass by heated groundwaters.

Detailed mineralogical and geochemical studies by George-Aniel and others (1991) document details of uranium migration during three or more stages characterized by distinct temperatures and chemical processes. First was a high-temperature stage in which U was mobilized and deposited in rhyolites as fine coatings. The high-temperature stage probably was deposition by a magmatic vapor phase during devitrification. Uranium moved within the rhyolite to become locally enriched at micron scale around iron-oxide minerals. In stage two hydrothermal fluids circulated within fractures in rhyolite, forming a high temperature kaolinite in structures, such as a breccia pipe at Nopal 1. This stage was oxidizing, and cooled from about $250^{\circ} \mathrm{C}$ to $150^{\circ} \mathrm{C}$, and fluids had 0.0 to 4.9 wt. percent $\mathrm{NaCl}$ equivalent salinity. Mixing with a fluid rich in $\mathrm{H}_{2} \mathrm{~S}$ caused uraninite and pyrite to be deposited. This stage is not dated, but could be either that of the $44 \mathrm{Ma}$ rhyolite of the Nopal Formation or coeval with a younger 38 or $37 \mathrm{Ma}$ rhyolite (George-Aniel and others, 1991). Stage three was a lower temperature hydrothermal event (about $100-150^{\circ} \mathrm{C}$ ) that caused oxidation and montmorillonite alteration. Stage four was supergene oxidation with precipitation of $\mathrm{U}^{+6}$ phases. Finally, 
stage five formed uranophane-opal-iron oxide deposits after young faulting and hotsprings activity.

Uranium resources as of 1991 (George-Aniel and others, 1991) were 333 t $\mathrm{U}_{3} \mathrm{O}_{8}$ at 0.11 percent $\mathrm{U}_{3} \mathrm{O}_{8}$ at Nopal I; 350 t $\mathrm{U}_{3} \mathrm{O}_{8}$ at 0.106 percent $\mathrm{U}_{3} \mathrm{O}_{8}$ at Margaritas; and 498 t $\mathrm{U}_{3} \mathrm{O}_{8}$ at Puerto 3 (grade not specified). Mining started at the Nopal I deposit before 1981 and a mill was under construction when all mining and related activities were stopped in 1982. All researchers favor the glassy rhyolites as the source of the uranium. For the area as a whole, the numerous occurrences and prospects (more than 100) are essentially strata-bound within two rhyolites, suggesting that the $U$ did not move far. The major host and source, rhyolites of the Nopal Formation, is only moderately enriched in uranium, but fission track studies show that 70 percent of the $U$ was in the glassy matrix that has $8 \mathrm{ppm}$ in the freshest samples. The location and form of $U$ in the volcanic rock is more important than the total amount in the rock (George-Aniel and others, 1991). This is consistent with the concept of "fertilility" as used by French geochemists.

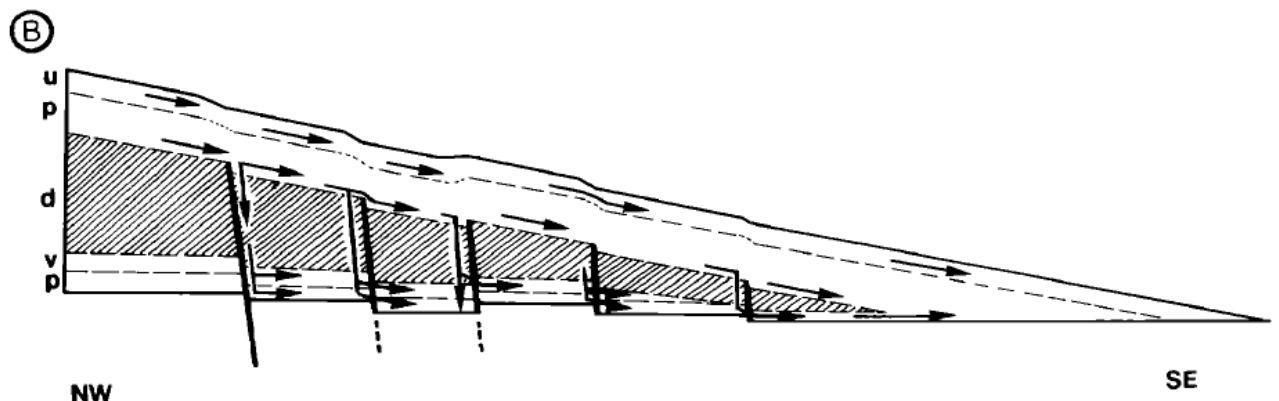

(A)

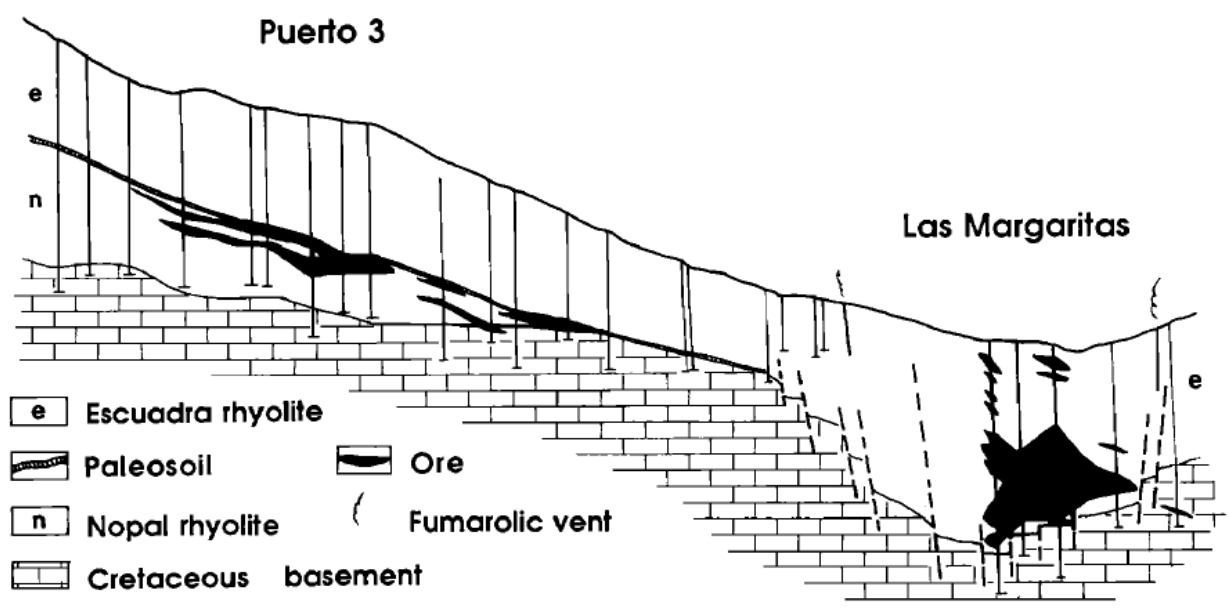

Figure 4. Cross section of the Puerto 3 and Las Margartas deposits, Pena Blanca District. The tabular form of the Puerto 3 deposit reflects permeability parallel to beds, whereas the more vertical form of Las Margaritas reflects fractures described as a pipe. (fig. 12 of George-Aniel and others, 1991; (C) Society of Economic Geologists). 
The supergene processes and oxidized uranium minerals in the Pena Blanca District are similar to those observed at several other volcanogenic deposits in the United States and Italy (Curtis, 1981). The earliest stage of devitrification of rhyolite and vapor phase mobilization of uranium onto iron oxide phenocrysts is of interest to the author: this probably happens in other glassy tuffs or domes but has not been documented by the special methods used by the CREGU group in France (George-Aniel and others, 1991). Also noteworthy, George-Aniel and others (1991) observed and emphasized changing physical properties in the Nopal Formation: early fractures facilitated early flow of hydrothermal fluids on fractures, but later intense kaolinization made the rhyolite impermeable to some later stages of hydrothermal flow and thus did not receive that stage of uranium.

\section{Macusani District, Peru}

The Macusani District of southernmost Peru may be similar to the Pena Blanca District. It was identified during the mid-1980's lull in exploration, and studied by a team of IAEA consultants who gave it high praise. No drilling was done at that time, and there has been no mining to 2008, but an inferred resource of 2,500-5,000 t $U$ at $0.1-0.2$ percent $\mathrm{U}\left(2,950-5,900 \mathrm{t} \mathrm{U}_{3} \mathrm{O}_{8}\right.$ at 0.12 to 0.24 percent $\left.\mathrm{U}_{3} \mathrm{O}_{8}\right)$ is carried by the IAEA (2008). Host rocks are Tertiary layered rocks with seven cycles of tuff and ignimbrite (10 to $4 \mathrm{Ma}$ ) (Leroy and George-Aniel, 1992). Mineralization was briefly summarized as uraninite-pyrite and autunite-gummite (oxidized) minerals in veins in ignimbrite and only oxidized $U$ minerals as disseminations in tuffs. In recent years exploration concessions have been won by Canadian firms, including Cameca (the largest producer in the world), and more detailed exploration has led to drilling of about 100 holes through 2008. Press releases provide helpful new information (that is not verifiable or peer reviewed); the showings and drill intercepts are consistently described as containing $\mathrm{U}^{+6}$ minerals, and initial tests of bulk samples show high solubility in acidic leachates. Approximately 40 radiometric anomalies and showings have been identified over a large area $(20 \times 15 \mathrm{~km})$, but no details of deposit geology have been presented. However, petrologists undertook studies of the highly fractionated Macusani volcanics (Pichavant and others, 1988; Cuney and others, 1992) that are somewhat more fractionated than topaz rhyolites (described later). The behavior of $U$ in the Macusani volcanics was studied in detail and found to be higher in concentration ( 20 or more ppm $U$ ) but somewhat less leachable than the $U$ in the vapor-phase altered Pena Blanca volcanics (Leroy and George-Aniel, 1992). The new exploration information suggests that this district is indeed well endowed with uranium and the challenge now is to find higher grades of mineralization. Many intercepts reported in press releases (2007-2009) are in the 0.01 to 0.07 percent $\mathrm{U}_{3} \mathrm{O}_{8}$ range, but some are above 0.2 percent.

\section{Lakeview District, Oregon}

The White King Mine in southeastern Oregon (fig. 5) was one of the largest producers of uranium from volcanic rocks of the western United States, producing most of the nearly 400,000 lbs (182 tonnes) of $\mathrm{U}_{3} \mathrm{O}_{8}$ from the district (Castor and Berry, 1981). Discovery was in the 1950 s, with mining prior to 1960 . Ore bodies were in brecciated flow-banded rhyolite that is part of an intrusive dome. The peralkaline rhyolite was 
altered to secondary K-feldspar and microcrystalline quartz prior to brecciation and ore deposition. Volcano-sedimentary rocks adjacent to the dome also contained ore.

Samples from the pit are enriched in $\mathrm{Ag}, \mathrm{As}, \mathrm{Cr}, \mathrm{Hg}, \mathrm{Mo}, \mathrm{Pb}, \mathrm{Sb}, \mathrm{W}, \mathrm{Y}$, and $\mathrm{Zn}$, but are low in fluorine (Castor and Berry, 1981). Content of Th was low. The primary ore minerals are uraninite and coffinite, and yellow uranium minerals occur in zones with brown limonite. Select samples contain up to one percent $\mathrm{U}_{3} \mathrm{O}_{8}$ and a shear zone near the pit contain 0.1 percent; the average grade of mined ore has not been published. The alteration phases, geochemical enrichments, and geologic associations indicate that the uranium was deposited from hydrothermal fluids related to peralkaline rhyolite intrusions (Castor and Berry, 1981; Castor and Henry, 2000). 


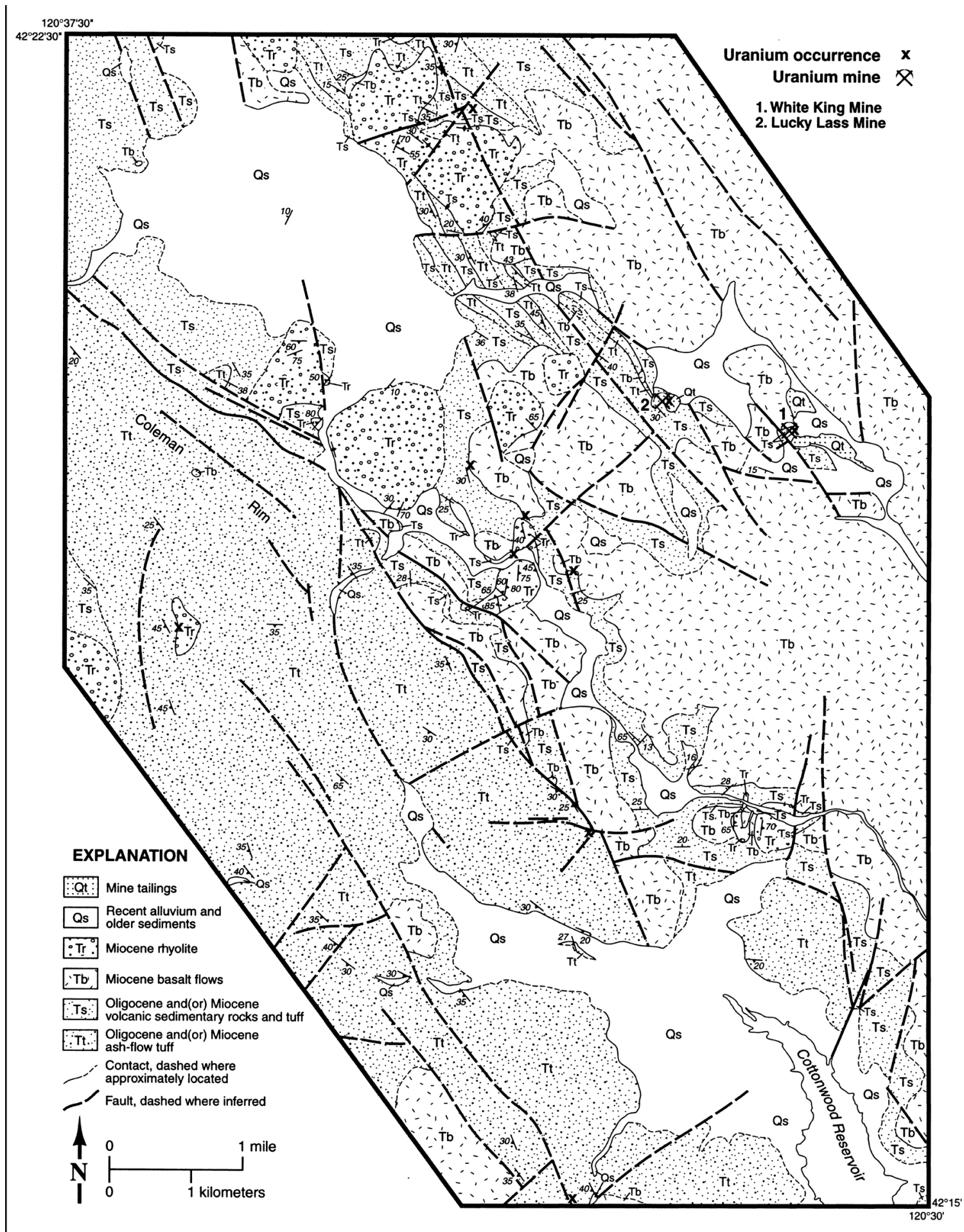

Figure 5. Geologic map of the Lakeview District. (Castor and Berry, 1981, AAPGC 1981, reprinted by permission of the AAPG whose permission is required for further use.) 
Other prospects in the district, and the Lucky Lass deposit, which had production, are in sheared and altered tuff and tuffaceous sediments, generally adjacent to rhyolite domes. All are considered to be hydrothermal in origin by those who studied the mines and prospects (Castor and Berry, 1981; Castor and Henry, 2000).

The White King Mine pit filled with water after about 1960, which blocked access by Castor and others nearly 20 years later. However, the geological and geochemical studies are fairly complete. Ideally, fluid-inclusion, stable-isotope, and geochronologic studies would be made to produce a model of ore genesis. Records of drill-hole and blast-hole assays, and mining grades and tonnages are not available to the public, which is common for uranium mine and mill records. Nonetheless, the White King Mine is a reasonable reference locality, proximal in the spectrum of volcanogenic uranium deposits.

\section{McDermitt District, Nevada and Oregon}

The McDermitt caldera complex contains numerous uranium prospects and several quasi-economic deposits in close proximity but somewhat different settings. The geology, geochronology, petrochemistry, ore geology and ore geochemistry are very well understood from the detailed studies of Rytuba and others (Rytuba and Glanzman, 1979; Rytuba and Conrad, 1981), and Castor and Henry (2000). In addition, important information has been released by exploration companies (Roper and Wallace , 1981; Myers, 2005). Although research and industry geologists disagree on genetic details, there is good agreement on aspects of interest here, and abundant descriptive geochemical data. The McDermitt complex contains as many as four overlapping calderas that erupted huge volumes of peraluminous to metaluminous ash about $16 \mathrm{Ma}$. The main caldera complex, probably resurgent, was then filled by a complex sequence of tuffs, rhyolite and mafic flows, which are in turn cut by small rhyolite intrusions. Hydrothermal activity and mineralization of several types (mercury is most famous) continued for about $4 \mathrm{Ma}$. The petrochemistry of the volcanic rocks is distinctive and fascinating in many ways, but for uranium exploration the spatial association with rhyolites containing exceptionally high $\mathrm{U}$ and Th has been emphasized by Castor and Henry (2000). Freshest (glassy) samples contain 12-15 ppm U and 19-28 ppm Th. This topic will be discussed further in a later section. Also noteworthy is the mobility and enrichment of $\mathrm{Zr}$ in U-rich zones, attaining concentrations of several percent as hydrothermal Zr. The radioactive zones, prospects, and deposits are enriched in a suite of elements typical of epithermal deposits, including As, Bi, Mo, Te, Tl, and of course $\mathrm{Hg}$ (Castor and Henery, 2000). Uraninite, coffinite, botryoidal pyrite, marcasite, arsenopyrite, cinnabar, and fluorite were primary minerals. The most significant deposits are the Aurora and Bretz deposits near the northeastern margin, and the Kings River and Moonlight deposits at the southwest margin.

\section{Aurora Prospect, McDermitt, Nevada-Oregon}

This drilled, but unmined, prospect is in mafic lavas within the moat of the McDermitt caldera, astride the Nevada-Oregon border. While geology and geochemical descriptions are incomplete, the information and concepts provided by Roper and Wallace (1981) and Wallace and Roper (1981) are sufficient for a fairly specific 
reconstruction of a purportedly rare uranium environment that should exist in other terranes. Following collapse of the McDermitt caldera, a lake formed that collected a complex sequence of varved sediments, diatomite, opal horizons, carbonaceous beds, and mafic lavas (fig. 6). Pyrite is widespread and abundant, some presumably as a replacement of magnetite, especially in the mafic (icelandite) flows. Steeply dipping structures are described as likely hypogene (hydrothermal) mineralization zones, whereas uranium zones with low dip are said to reflect supergene redistribution. Roper and Wallace (1981) propose that opal layers reflect hot springs activity and that the mafic composition was important for the formation of pyrite. Several genetic relationships remain unclear, including the relationship to the nearby Bretz mercury- U deposit (outside the caldera), and to the peralkaline-silicic McDermitt magma and tuffs that are known to be rich in U (Rytuba and Conrad, 1981). Likewise, the details of sulfidation and uranium precipitation are not established. By analogy to sandstone-type deposits studied in detail by Reynolds and Goldhaber (1983), we know that several forms of sulfide ion are powerful reductants and could be relevant at temperatures up to about $200^{\circ} \mathrm{C}$. 


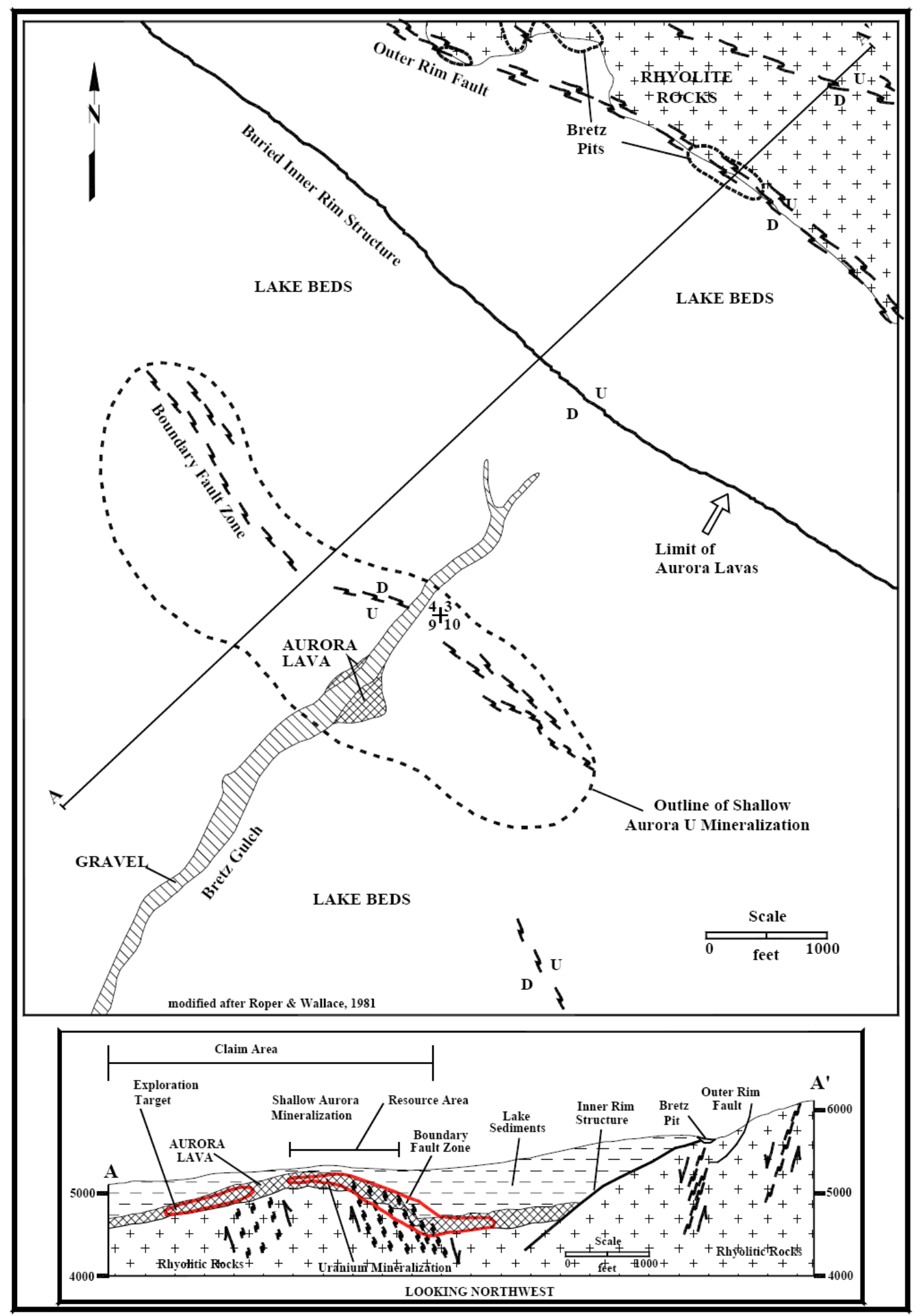

Figure 6. Geologic map and cross-section of the Aurora deposit. (fig. 9-7 of Myers, 2005). 
The Aurora prospect was thoroughly drilled from 1977 to 1980 and found to be at least 3,660 $\mathrm{m} \times 1,070 \mathrm{~m}$, with at least two mineralized horizons (beds, flows) averaging 1.5 to $2.1 \mathrm{~m}$ thick (Roper and Wallace, 1981). ${ }^{4}$ In detail the uranium zones are lensoid (fig. 7); one of the controls on these lenses may be porosity provided by flow-top vesicles. Grade distribution and milling character were not reported. The conclusions in 1981 were positive but vague: Aurora is a "potentially economic deposit", and "The uranium occurrences at Bretz and Aurora are without doubt the largest in total pounds of contained uranium yet found in Tertiary volcanic rocks of the United States" (Wallace and Roper, 1981). A preliminary resource calculation in 1980 was "roughly 17 million tons at a grade of 0.05 percent $\mathrm{U}_{3} \mathrm{O}_{8}$ (or 15.4 million tonnes of ore and about 7,700 tonnes contained $\left.\mathrm{U}_{3} \mathrm{O}_{8}\right)$."

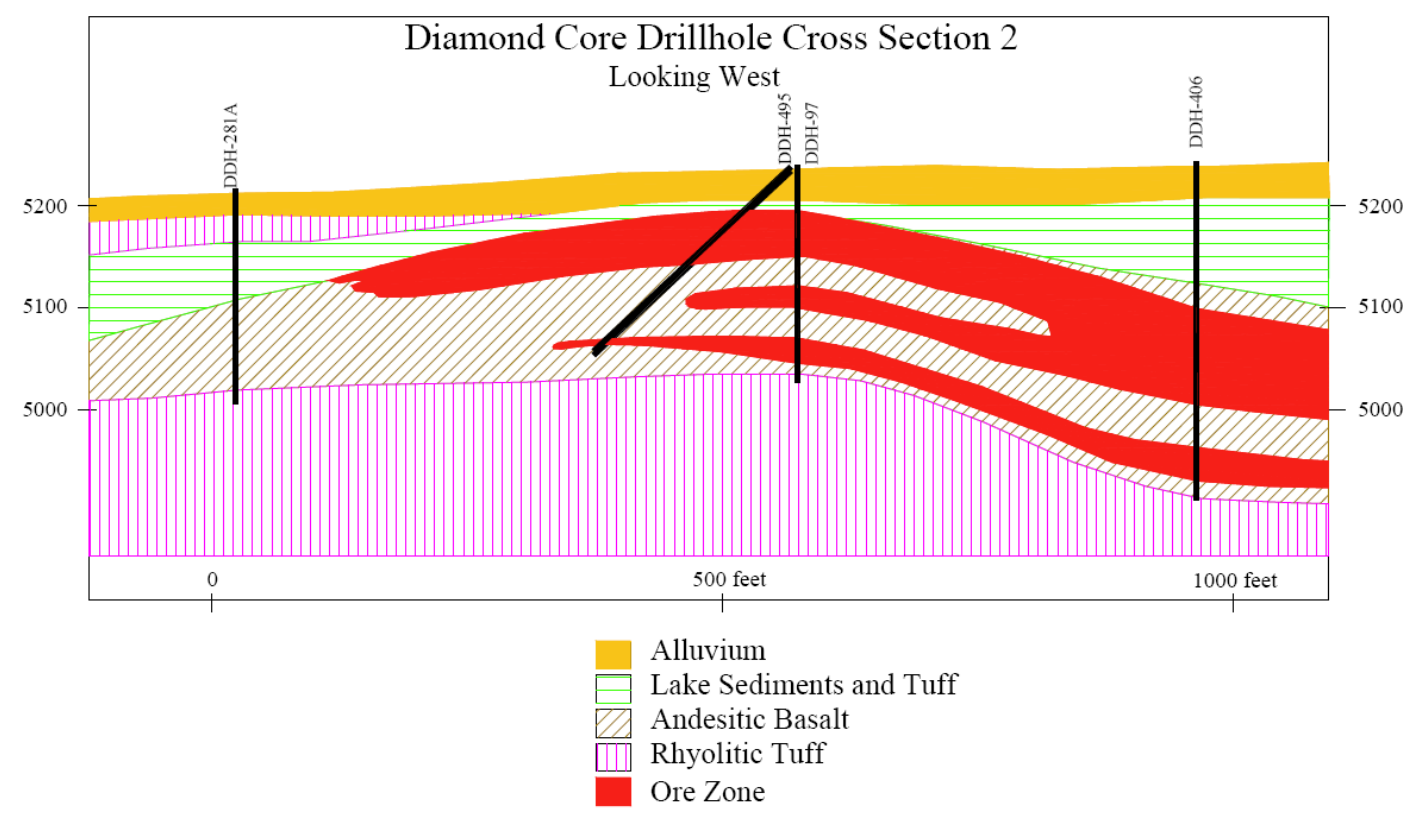

Figure 7. Cross section showing geology and ore lenses, Aurora deposit, based on drill core (information from rotary drill holes also is available). The lens-like ore geometry is thought to reflect primary features in the andesitic basalt flows, such as flow tops. (fig. 11-1 of Myers, 2005).

${ }^{4}$ Recent press releases by exploration companies provide many facts that were not reported by uranium-mining companies in the past; these are not peer-reviewed. An 81-page report on the Aurora deposit was released to the public by Quincy Energy Corp 
(Myers, 2005). The tables of data, maps, and cross sections are very detailed, reflecting skilled professional work from the 1970s. This is possibly the best public dataset for any volcanogenic uranium deposit, thanks in part to the new reporting requirements of the Toronto Stock Exchange.

No new work was done for the Myers report (2005), and geologic descriptions are not significantly different from those presented by Roper and Wallace (1981), but the reported geotechnical information is more complete. Metallurgical tests are reviewed for a rare glimpse at uranium ore behavior in various commercial leach processes. Recovery ranged from a low of 55 percent in "strong acid" (presumably sulfuric, an industry standard), to 80 percent (strong acid, $80^{\circ} \mathrm{C},+20$ percent sodium chlorate), and 85 percent ( acid pressure leach). These tests suggest a "pyrite lockup" problem similar to the well known refractory behavior of unoxidized gold-pyrite ores, which for many years were considered uneconomic to process. Reserves and resources are carefully discussed, with clear comments on aspects such as drill hole spacing and cutoff grades. Because the drill spacing does not meet current stock market criteria for "reserve" (NI 43-101 standard), the highest level of confidence is an indicated resource of 18.3 million pounds at an average grade of 0.0518 percent $\mathrm{U}_{3} \mathrm{O}_{8}$, assuming a cutoff grade of 0.03 percent $\mathrm{U}_{3} \mathrm{O}_{8}$.

The Bretz mercury mine is about $1 \mathrm{~km}$ north of the Aurora deposit, in outflow ash-flow tuff and lavas. The Bretz Mine consists of a series of small elongate pits located on faults and fractures that follow the caldera margin. Radioactive rock is silicified and brecciated, enriched in $\mathrm{Hg}$, As, $\mathrm{Mo}, \mathrm{Pb}, \mathrm{W}$ and $\mathrm{F}$, and samples range up to 0.1 percent $\mathrm{U}_{3} \mathrm{O}_{8}$ (Castor and Henry, 2000; Wallace and Roper, 1981). Diverse sulfide minerals are present, but no U minerals could be identified. The uranium zones cut both $\mathrm{Hg}$ mineralization and silica-kaolinite alteration and are associated with veinlets of montmorillonite and framboidal pyrite (Wallace and Roper, 1981). The uranium zone is restricted to the caldera-margin fracture zone. The best uranium values seemed to be along relatively flat-lying unconformities in the volcanics, near the ring fracture zone.

The Aurora prospect is a very attractive conceptual exploration target, the likes of which could exist in many other volcanic systems. The ingredients are simple and common: caldera moat lake sediments; iron-rich flows; and evidence of hot-spring activity, sulfur emanations, and uranium-enrichment in subjacent rocks. Many styles of fluid flow and fluid mixing are likely. The mixing fluids were meteoric, warm to hot, oxidized and reduced, with no need for magmatic input other than heat in the later stages of the volcanic cycle. For the Aurora model, magnetic surveys should be effective: seeking a magnetic low where magnetite is replaced by pyrite. A problem for geologic understanding, mentioned by Roper and Wallace, is that important lithologic and structural features in the moat-filling sequence are not well-exposed.

\section{Kings River area (Moonlight Mine)}

The only recorded uranium production from the McDermitt District was from the Moonlight Mine, in an area of cross-cutting faults that comprise the western margin of 
the caldera . Exploration in the 1970s identified several additional zones of mineralization along margin fractures. Production was about $600 \mathrm{~kg} \mathrm{U}_{3} \mathrm{O}_{8}$ at an average grade of 0.13 percent $\mathrm{U}_{3} \mathrm{O}_{8}$ (Castor and Henry, 2000). Ore was in a fault breccia zone of bleached and limonitic pre-caldera rhyolite. The uranium is in uraninite, coffinite, and yellow hexavalent minerals and also in a refractory U-Zr-silicate. Samples contain as much as 5 percent $\mathrm{Zr}$, and also are rich in As, Mo, and trace metals typical of epithermal deposits. Sulfide minerals include arsenopyrite and at least two stages of pyrite, one framboidal. Gangue minerals include fine-grained and drusy quartz, adularia, and white and purple fluorite. Thorium is enriched in the peralkaline rocks, but not in the Moonlight ores which average $13 \mathrm{ppm}$ Th.

The Moonlight and adjacent deposits of the Kings River area are interpreted to have formed in the deepest part of the system, at the caldera floor (Castor and Henry, 2000). No age determinations are available for $U$ minerals, but an ${ }^{40} \mathrm{Ar} /{ }^{39} \mathrm{Ar}$ age of 16.1 Ma on adularia replacing feldspar phenocrysts near Moonlight ore is their (Castor and Hency, 2000) best approximation of the age of primary $U$ deposition; this age is indistinguishable from the age of caldera-forming tuff. Castor and Henry (2000) calculate a depth of $1000 \mathrm{~m}$ for ore formation, similar to the estimate of $800 \mathrm{~m}$ by Rytuba and Glanzman (1979). Fluid inclusions in quartz suggest a temperature of about $330^{\circ} \mathrm{C}$ (Rytuba and Glanzman, 1979).

\section{Marysvale District, Utah}

Uranium-bearing veins were discovered in 1949, nearly a century after base- and precious-metal veins. Pitchblende, coffinite, and associated silica, fluorite, pyrite, and adularia fill discontinuous veins in quartz monzonite, granite, and rhyolite dated at 23-19 Ma (Steven and others, 1981; Cunningham and others, 1998). Minerals associated with U-bearing veins include molybdenite, jordisite (amorphous $\mathrm{MoS}_{2}$ ), hematite, magnetite, and marcasite. Molybdenum enrichment, and a $\mathrm{U}-\mathrm{Pb}$ date of $19 \mathrm{Ma}$ on pitchblende, tie the U-bearing veins to a postulated molybdenum-porphyry intrusion at depth. Rhyolite tuff and rhyolite dikes, both about $19 \mathrm{Ma}$, overlie and intrude the stocks. Rhyolite is a possible source of $\mathrm{U}$. Production from the vein deposits was $608 \mathrm{t} \mathrm{U}_{3} \mathrm{O}_{8}$ at a grade of about 0.22 percent (Chenoweth, 1991) from 1949 to 1969.

Detailed field and laboratory studies (Cunningham and others, 1998) establish the paragenetic sequence and hydrothermal conditions at Marysvale. U-Mo-F-rich veins were deposited at $200-270^{\circ} \mathrm{C}$ from solutions with 0.0 to 2.6 wt percent $\mathrm{NaCl}$ equivalent salinity. Based on calculations relating to boiling, the top of the vein was within $115 \mathrm{~m}$ of the ground surface. At the deepest levels (about $400 \mathrm{~m}$ from the surface), wall rocks were altered to sericite, and uraninite, coffinite, jordisite, fluorite, molybdenite, quartz, and pyrite were deposited in fractures. As mineralizing fluids rose they were progressively oxidized and cooled by boiling and degassing; hematite and uraninite were deposited with quartz and fluorite. At the highest levels, mineralizing fluids became acidic by oxidation of hydrogen sulfide and condensation of volatiles in steam-heated groundwaters. Mineralogical associations and thermodynamic calculations suggest that $\mathrm{U}$ was transported as a fluoride complex, and $\mathrm{U}$ was deposited as fluorite precipitated during cooling and alteration of plagioclase. Thorium does not seem to be involved in 
this F-rich system; it is not mentioned by Cunningham and others (1998) and chemical analyses do not show any correlation between $\mathrm{F}$ and $\mathrm{Th}$, in contrast to other F-rich hydrothermal systems. The alkali rhyolite volcanic rocks at Marysvale were rich in U (10 to $18 \mathrm{ppm}$ ) and should have been a good source for $U$ in hydrothermal fluids or groundwaters (Steven and others, 1981). Cunningham and others (1998) favor a primary source of $U$ in the magma chamber represented by dikes and a shallow stock, but stable isotopes indicate that "the hydrothermal fluids were dominantly meteoric...including a small percentage of magmatic water."

In the 1950s, Marysvale vein deposits probably were considered to be a significant alternative to sandstone-type deposits of the Colorado Plateau. However, even with the contracts and bonuses from the U.S.Atomic Energy Commission (AEC), the production was quite small. With experience elsewhere in the United States and the world, and an open market for U, the focus later shifted to other kinds of deposits (Nash and others, 1981).

Undiscovered resources of $U$ at Marysvale could be large according to Steven and others (1981) who suggested hypothetical U deposits in intracaldera fill and clastic-filled basins adjacent to the volcanic complex. I concur with Steven and others that there could be large amounts of groundwater-mobilized uranium in these clastic basins. The chief unknowns are the types and locations of traps and reductants.

\section{Rexspar Deposit, Canada}

The Rexspar deposit in British Columbia (Preto, 1978) has some similarities to Marysvale: it is even richer in fluorine than Marysvale, but the ore minerals differ from Marysvale. Rexspar is impressively rich in F and F-bearing phases such a fluorphlogopite. As in a few other F-rich hydrothermal U systems, the amount of Th exceeded $U$ (two- to three-fold) and much of the $U$ resided in uranothorite, a refractory Th-rich phase with the isometric uraninite structure. As of 1978, production and reserves at the Rexspar Mine were about 861,000 tonnes $\mathrm{U}_{3} \mathrm{O}_{8}$ at a grade of 0.077 wt percent $\mathrm{U}_{3} \mathrm{O}_{8}$. The same thorium enrichment and uranothorite was found in veins at Bokan Mountain, a deposit associated with highly evolved F-rich, alkali granite (Thompson, 1988; Cuney and Kyser, 2009).

\section{Georgetown-Townsville Uranium Field, Australia}

The Georgetown-Townsville uranium field in Australia consists of a cluster of prospects and drilled deposits in rhyolitic ignimbrites (ash flow tuffs) associated with calderas, ring dikes, linear structures and co-magmatic intrusives (Bain, 1977; McKay and Miezitis, 2001). Large-scale volcanic and hydrothermal activity spanned Late Devonian to Early Permian time. The deposits and prospects are characterized by the UMo-F association, and hydrothermal processes were similar to those at Marysvale, Utah. Structural controls include zones of intensely fractured rhyolite, breccia pipes, fault zones, and permeable clastic rocks. Two deposits are substantial in size. Measured and indicated resources for the Ben Lomond deposit range from 4,700 to 6,792 t $\mathrm{U}_{3} \mathrm{O}_{8}$ at an average grade of 0.228 percent $\mathrm{U}_{3} \mathrm{O}_{8}$ (by various reporters; see those above), and for the Maureen deposit, 2,940 t $\mathrm{U}_{3} \mathrm{O}_{8}$ at 0.123 percent $\mathrm{U}_{3} \mathrm{O}_{8}{ }^{5}$. 
${ }^{5}$ The detailed geologic descriptions and engineering data from drilling (Vigar and Jones, 2005) provide a rare view of the Ben Lomond deposit. The report summarizes the results of work from 1975 to 1982 by French-owned companies (Pechiney and subsidiaries).

The report was written and released to the public in accord with standards of the Toronto Stock Exchange. Details are given on several resource calculations, that indicate a range of tonnages from 4,700 to 6,370 $\mathrm{t} \mathrm{U}_{3} \mathrm{O}_{8}$ depending upon assumptions. Also discussed are the implications for grade and tonnage dependent upon underground or open pit mining; one model suggested an average grade of 0.235 percent $\mathrm{U}_{3} \mathrm{O}_{8}$ for the open pit portion and 0.281 percent $\mathrm{U}_{3} \mathrm{O}_{8}$ for the underground part. Geologic details from more than 600 drill holes and underground test mining show that U-bearing veins are in a network of parallel structures in the host rhyolite, and that uranium values die out about $10 \mathrm{~m}$ below an unconformity. The veins are covered by post-mineral black shale and rhyolite deposited in a subsidence structure (caldera or linear graben). The ore minerals are uraninite, coffinite, molybdenite, jordisite, pyrite, arsenopyrite, marcasite, and trace amounts of chalcopyrite, sphalerite, and galena. The mineralized zone is characterized by strong silicification and hematite alteration of wall rocks; central sericite alteration grades outward to chlorite and pervasive dolomite alteration. The ore zone dips about 75 degrees; it outcropped on the west end (creating the radioactivity that allowed airborne discovery), and to the east is covered by up to $400 \mathrm{~m}$ of unmineralized (post-mineral?) rhyolite that hampers drilling and posses a problem for open pit mining. Vigar and Jones provide a thoughtful model of geologic stages (fig. 8). 
1

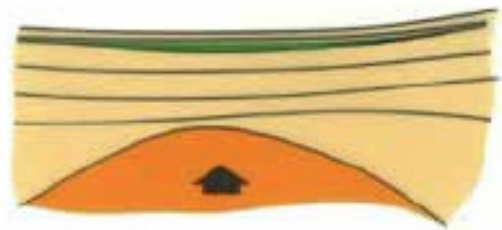

2

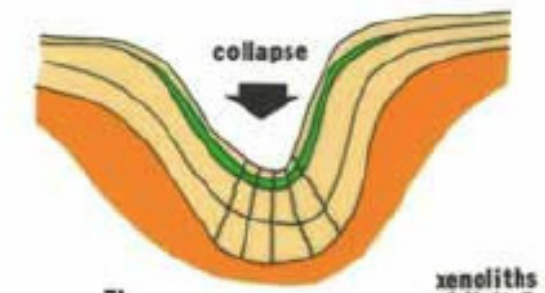

3

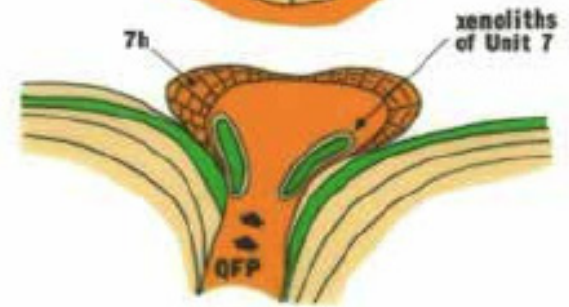

4

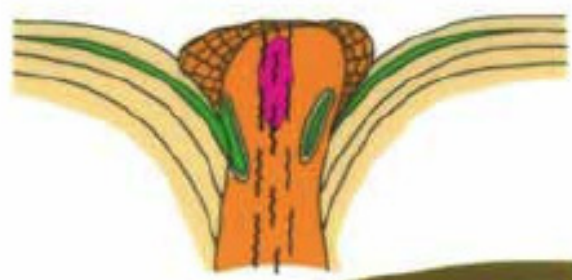

5

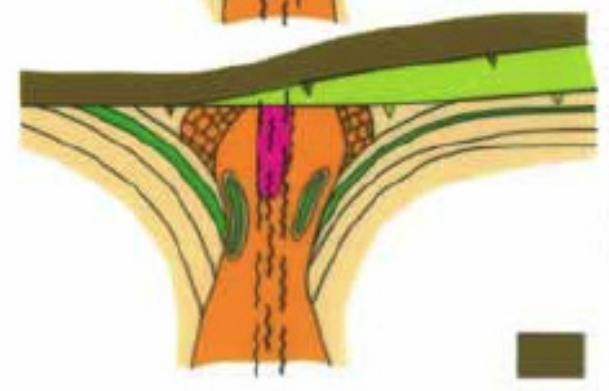

Watershed North Rhyolite (WNR)

Upper Andesite Member (UAM)

Quartz Feldspar Porphyry (QFP)

Unit 7

Black Tuff formation

Mineralization

Figure 8. Model of stages in the genesis of the Ben Lomond deposit. (fig. 8 of Vigar and Jones, 2005). 


\section{Novazza, Italy}

This deposit in northernmost Italy, in volcanic rocks of Carboniferous and Permian age, is considered by some as a prime example of a volcanogenic uranium deposit (for example, Curtis, 1981). Host rocks are interbedded felsic tuff, shale, volcaniclastic sediments, sandstone, and conglomerate; some tuffaceous beds contain carbonaceous material. The ore zone comprises lenses with an aggregate thickness of as much as $40 \mathrm{~m}$. With a resource of $1,455 \mathrm{t} \mathrm{U}_{3} \mathrm{O}_{8}$ at about 0.146 percent $\mathrm{U}_{3} \mathrm{O}_{8}$, Novazza is a fairly large deposit. Results of a mineralogical study of U-associated tourmaline (Fuchs and Maury, 1995) suggest unconventional processes at Novassa. In their thorough review of borosilicate alteration associated with what they term U-Mo-Zn and Ag-Au-Zn ores in volcanic rocks, Fuchs and Maury draw parallels to ores hosted in the Triassic Koipato Formation at the Rochester District, Humboldt Range, Nevada, (for example, Vikre, 1981). The Koipato-hosted ores of the Humboldt Range are some of the most enigmatic and debated of ores in Nevada, so the analogy is useful but does not provide clarity. Fuchs and Mauray argue that the tourmalines are evidence for mesothermal conditions (about $350^{\circ} \mathrm{C}$ ), and a spatial distribution external to a core zone characterized by phases such as pyrophyllite, andalusite, and dumortierite, the latter Al-silicates probably forming from a kaolinite-alunite-jasperoid protolith (as in acid-sulfate alteration). This is very complicated, although not typical of most alteration systems in volcanic rocks. These insights from Fuchs and Maury (1995) provoke thoughts for a new variant on uranium in volcanic rocks, by metamorphic processes rather than diagenesis and geothermal alteration. The volcanogenic $U$ model should not include the unusual features of the Novazza deposit.

\section{Spor Mountain, Utah}

This area is famous for its unusual, large but low-grade volcanogenic deposits of beryllium, and for a time saw modest production of uranium (Lindsey, 1977, 1981, 1982). In this area there are numerous kinds of deposits, all with a Be-F-U association. These deposits include beryllium (as bertrandite) disseminated in tuff, fluorspar pipes in carbonate rocks, and one significant concentration of hexavalent uranium minerals in volcanic sandstone. Minor but anomalous amounts of uranium occur both within and outside beryllium deposits, and uranium occurs in some, but not all, fluorspar deposits. In beryllium and fluorspar deposits, uranium occurs as uraniferous opaline silica, as uranophane, and probably in the structure of fluorite.

All of the deposits at Spor Mountain formed during or after eruption of fluorineand lithophile-rich alkali rhyolite 21 million years ago. At Spor Mountain, and over much of western Utah, alkali rhyolite and basalt have been interpreted as the products of bimodal volcanism during basin-range faulting. Bimodal volcanism may overlap cauldron formation in some parts of the basin-and-range, but at Spor Mountain it is postcaldera.

Uranium in volcanic sandstone and conglomerate was discovered in The Dell, immediately east of Spor Mountain, in 1953, and mined from 1959 to 1962. Production was about $191 \mathrm{t} \mathrm{U}_{3} \mathrm{O}_{8}$ at 0.20 percent $\mathrm{U}_{3} \mathrm{O}_{8}$ (Chenoweth, 1991), entirely from one mine, the Yellow Chief. The host sandstone and conglomerate directly underlies tuff and 21- 
Ma-old rhyolite. Ore formed near a normal fault that follows the older ring-fracture system of the Thomas caldera (fig. 9). Uranium, as beta-uranophane ( $\mathrm{U}^{+6}$-Ca-silicate), occurs in lenses that are parallel to bedding in volcanic sandstone and conglomerate.

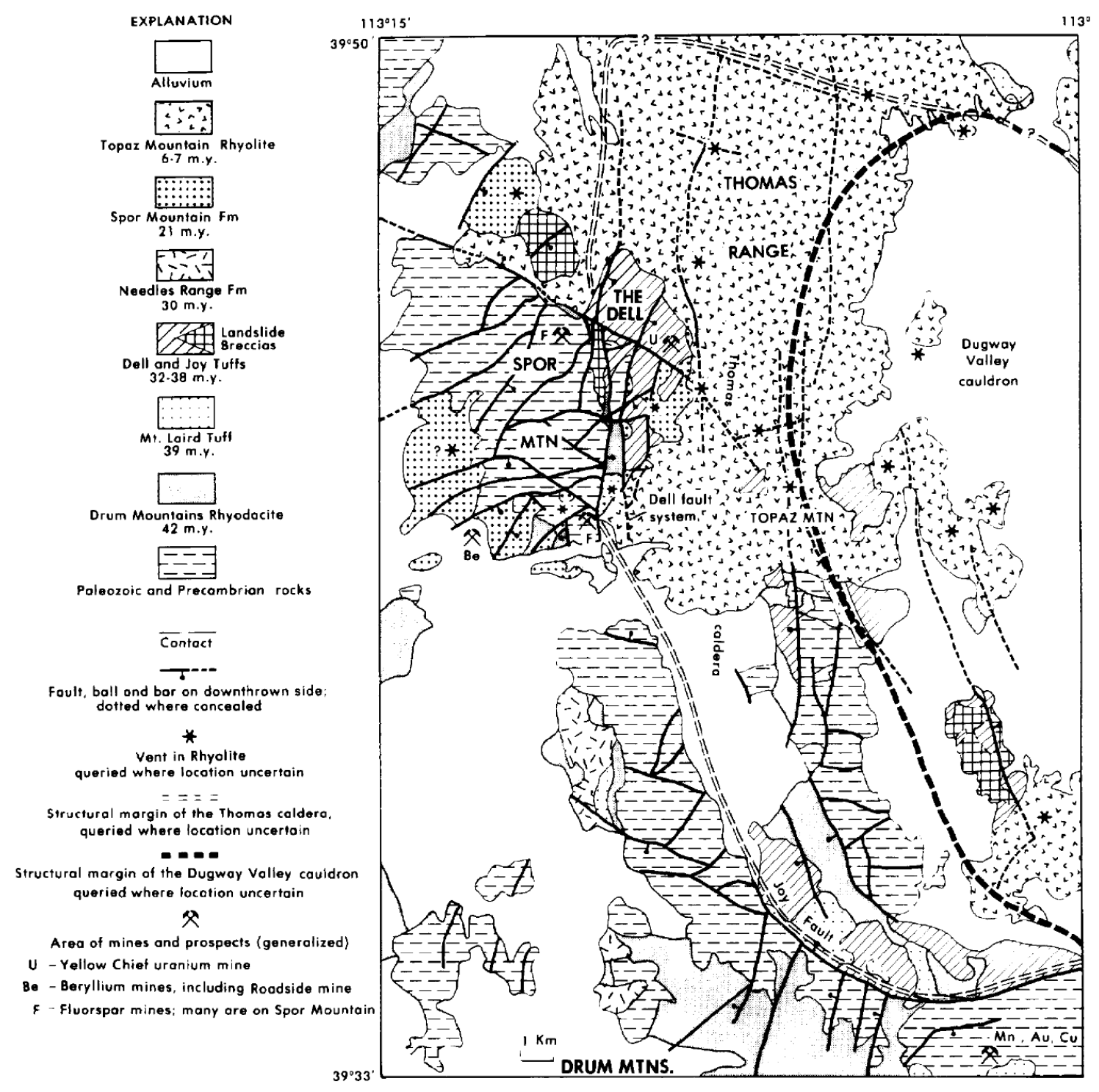

Figure 9. Simplified geologic map of the Spor Mountain area, showing $U, B e$, and fluorspar mines and prospects. Note the curving structural margin of the cauldron. (fig. 2 of Lindsey, 1981, AAPG@ 1981, reprinted by permission of the AAPG whose permission is required for further use.)

Three processes at Spor Mountain concentrated uranium (Lindsey, 1981): 1) alkali rhyolite magmatism and associated magmatic fluids that became enriched in Be, F, and $\mathrm{U} ; 2$ ) hydrothermal transport of $\mathrm{F}$ into carbonate rocks and Be into tuffs (with minor $\mathrm{U}$ ); and 3) groundwater leaching of magmatic and hydrothermal U minerals and redeposition in tuffs. These groundwaters also could have leached $\mathrm{U}$ from overlying 
volcanic rocks that are enriched in U. Of interest is the enrichment of thorium in tuff zones that contain high $\mathrm{F}$ concentrations (Lindsey, 1981). In the volcanic framework used in this report, Spor Mountain contains features of proximal, distal, and pre-volcanic structural settings.

\section{Date Creek Basin, Arizona}

The Miocene Date Creek basin in Arizona contains widespread uranium in a lacustrine facies of volcaniclastic rocks (Sherborne and others, 1979; Mueller and Halbach, 1983; Otton, 1985; figure 10). The Anderson Mine had minor production 19551959 , about $15 \mathrm{t}_{3} \mathrm{O}_{8}$ at 0.15 percent $\mathrm{U}_{3} \mathrm{O}_{8}$ (Chenoweth, 1991), but major exploration in the 1970's outlined large volumes of mineralized rock containing 0.01 to 0.1 percent $\mathrm{U}_{3} \mathrm{O}_{8}$, and some local zones with grades above 0.2 percent. Average grades are 0.07 percent; the estimated resource may be about $21,400 \mathrm{t} \mathrm{U}_{3} \mathrm{O}_{8}$ using a cutoff of 0.03 percent. There has been no new mining of these drilled resources as of 2008. Chemically, the $\mathrm{U}$ zones are enriched in $\mathrm{Mo}, \mathrm{V}, \mathrm{Li}, \mathrm{F}$, and $\mathrm{S}$, as in several other volcanogenic uranium deposits. The major difference between the Date Creek U deposits and deposits in other volcanic environments is the association with organic carbon, which most scientists agree was a major factor in the diagenetic enrichment of $U$ in lacustrine facies. The Date Creek deposits are clearly transitional to the more productive sandstonetype U deposits of the western United States. I emphasize the tuffaceous component of the lacustrine sediment and the release of uranium during diagenetic alteration of tuff, which is advocated by others for many volcanogenic uranium deposits. The primary $\mathrm{U}$ concentration in the tuffs may have been about 25 ppm (Sherborne and others, 1979), but this is difficult to establish because of the widespread alteration. 


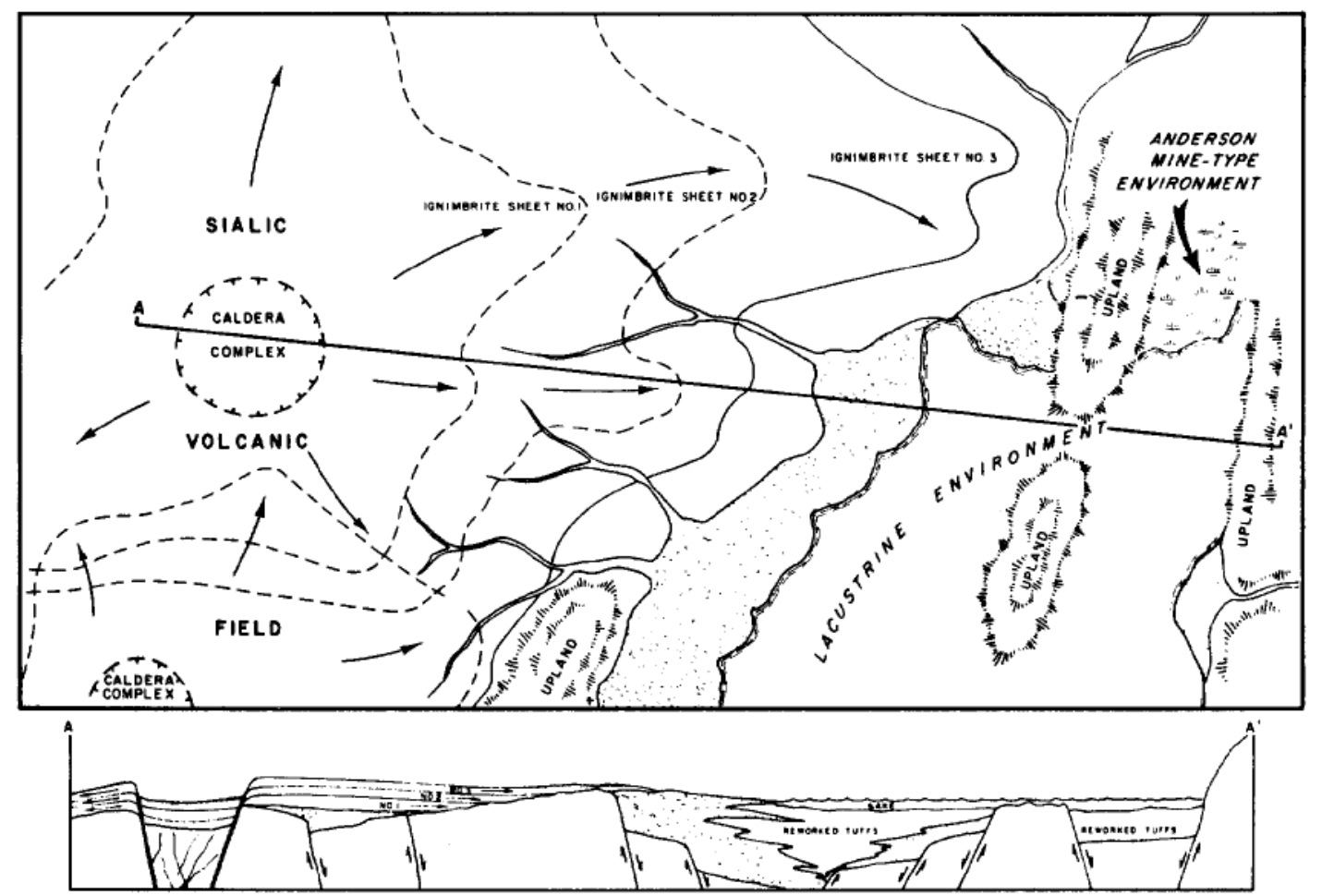

Figure 10. Schematic map and cross section showing the paleoenvironment of the Date Creek area. (fig. 9 of Sherborne and others, 1979, AAPG@ 1979, reprinted by permission of the AAPG whose permission is required for further use.)

The richest U zones at the Anderson Mine (Sherborne and others, 1979) are in carbonaceous strata, generally 1 to $3 \mathrm{~m}$ thick. For mining economics, a composite thickness of about $15 \mathrm{~m}$ was used to calculate resources. The drill-defined resource area is about 1,000 $\mathrm{m} \times 2,500 \mathrm{~m}$ in area. In detail, geologists recognize cross-cutting relationships that indicate epigenetic migration of uranium, and some of these crosscutting features contain higher grades. Genetic models propose that uranium was transported by diagenetic fluids into adjacent carbonaceous beds, perhaps by compaction and dewatering as in the lacustrine-humate U model (Turner-Peterson, 1985). This is an attractive model, but at Date Creek the distance of U transport probably was short, and the amount of enrichment at the site of precipitation was not large, probably because there was so much reactive carbon and diagenetic pyrite in many beds. Thus, the combined processes trapped large amounts of $\mathrm{U}$, but at disappointingly low concentrations. Further, the fine-grained nature of the ore, microscopically intergrown with carbonaceous material, probably would make milling by conventional methods 
difficult, similar to problems with "refractory gold" in fine-grained carbonaceous ores of the Carlin District, Nevada.

\section{Lodeve District, France}

The Lodeve District, France (Comte and others, 1986) has many features in common with the Date Creek deposits, but generally has been classified as sandstonetype (Finch and Davis, 1985). As pointed out by Otton (1985), the deposits at Lodeve have much higher grades than typical sandstone or lacustrine-type deposits, ranging up to 0.40 percent $\mathrm{U}_{3} \mathrm{O}_{8}$. Deposits in this basin contained about $21,200 \mathrm{t} \mathrm{U}_{3} \mathrm{O}_{8}$ at an average grade of 0.26 percent $\mathrm{U}_{3} \mathrm{O}_{8}$; the largest mined deposit, Mas Lavayre, contained 4,700 $\mathrm{t}$ $\mathrm{U}_{3} \mathrm{O}_{8}$ at 0.40 percent $\mathrm{U}_{3} \mathrm{O}_{8}$.

The Permian basin at Lodeve contains a thick sequence of clastic rocks, including many lacustrine beds rich in organic matter. Volcanic ash beds are abundant and well described. Uranium is believed to have accumulated syngenetically with the organic-rich lacustrine facies (Comte and others, 1986), but much uranium was remobilized into faults, fractures, and breccia zones that also trapped oil. Tectonic extension and compaction are believed to have mobilized newly formed petroleum during diagenesis, at temperatures below $200^{\circ} \mathrm{C}$. Oxidizing carbonate-rich meteoric water flushed out uranium and carried it through the same permeable zones that carried petroleum, which reduced and precipitated uranium. The Lodeve deposits have been thoroughly researched by French scientists, but the complex series of events remains confusing. The carbon compounds and their evolution have been studied in detail, revealing three types of carbon compounds, two of which are enriched in U (Schlepp and others, 2001). Many features described at Lodeve encourage speculation on possibilities for remobilization in lacustrine U deposits like those at Date Creek. Slump structures at Lodeve seem to be related to dewatering, possibly similar to ore-bearing structures in Blackbird District, Idaho, described by Nash and Hahn (1989). Dewatering and tectonically induced fluid flow may have driven the migration of hydrocarbons and uranium.

\section{Virgin Valley District, Nevada}

This remote area of northern Nevada has been known for its gem quality opal and uranium prospects since 1950; prospecting was intense in the 1950s and 1970s, but there has been no production. The uraniferous opal zones are well described by Zielinski (1982) and Castor and Henry (2000). In many places, the U is disseminated in opal with no detectable $U$ phase, but in some localities $\mathrm{U}^{+6}$ phases (silicates and carnotite) are found. The Virgin Valley U prospects are in rhyolitic bedded tuffs and lavas that fill a 16.3 Ma caldera that is about $25 \mathrm{~km}$ wide (Zielinski, 1982; Castor and Henry, 2000). Most of the radioactive zones are in fluvial and lacustrine tuffaceous sediments; lignite beds occur locally and some are slightly enriched in U. The tuffaceous rocks are altered to zeolites, montmorillonite, and opal by thermal waters of uncertain temperature (but probably less than $150^{\circ} \mathrm{C}$ ). The resource at Virgin Valley is reported to have a grade of 0.015 percent $\mathrm{U}_{3} \mathrm{O}_{8}$, and the median concentration of samples is 0.007 percent (Castor and Henry, 2000). These prospects have small size and such low U concentrations that they stretch the definition of "deposit." Alternatively, these can be seen as examples of altered rhyolitic tuffs and small intrusions that may have released $U$ in various 
hydrothermal or diagenetic processes, but without efficient transport and focused deposition, no significant concentrations (deposits) were created. The radioactive zones at Virgin Valley are what some exploration geologists call "teasers" because they are difficult to walk away from.

\section{Deposits in Pre-Volcanic Structural Traps}

\section{Pitch Mine, Colorado}

Brecciated dolomite and other rocks contain unusual deposits of uranium that may be related to Oligocene volcanic rocks (Nash, 1988). A major Laramide reverse thrust on the west side of the Sawatch Range created a large zone of brecciated, fractured, and sheared Precambrian granite; Mississippian dolomite; and Pennsylvanian black shale and sandstone. Mining from 1959 to1962 was underground on what was then considered to be a vein. In the 1970s, new concepts were used to drill more broadly in the fault zone, to define a bulk-minable deposit amenable to open-pit mining. The newly defined mineralized zone was more than $100 \mathrm{~m}$ wide and more than $1,400 \mathrm{~m}$ long.

Underground mining produced about $454 \mathrm{t}_{3} \mathrm{O}_{8}$ at an average grade of 0.50 percent $\mathrm{U}_{3} \mathrm{O}_{8}$, whereas the newly defined zone had a reserve of about $3,245 \mathrm{t}_{3} \mathrm{O}_{8}$ at 0.17 percent $\mathrm{U}_{3} \mathrm{O}_{8}$ (Ward, 1978). Mining ceased in 1982, recovering only part of the reserve, in part because the ore was hauled about $650 \mathrm{kms}$ to the Homestake Mill in Grants, New Mexico for processing. Construction of a mill near the site was controversial because of the high snowfall and mountainous location. 


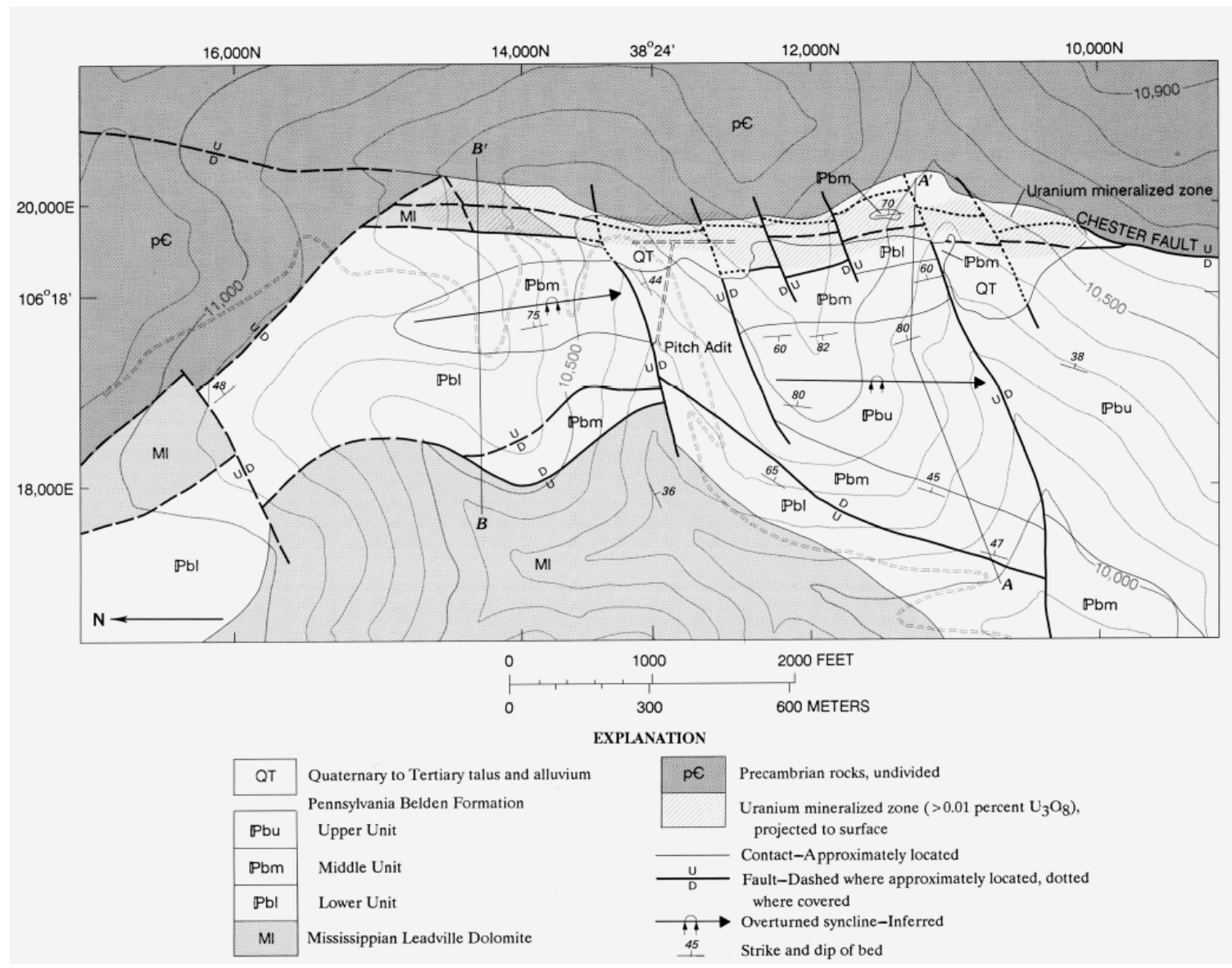

Figure 11. Geologic map of the Pitch Mine. (from Nash, 1988)

In the Pitch Mine, uraninite and coffinite occur with abundant pyrite, marcasite, and fine-grained silica in the ore zone. Oxidation of the ore body is minor. The dolomite (technically dolomicrite) is uniformly brecciated in the fault zone, and is clearly the favored ore host with grades in excess of 0.5 percent $\mathrm{U}_{3} \mathrm{O}_{8}$. Fault slices of other rocks (sandstone, shale, and granite) tend to be sheared or slightly fractured, and generally contain 0.1 percent $\mathrm{U}_{3} \mathrm{O}_{8}$ adjacent to high-grade ore in brecciated dolomite. The mineralized zone contains very low concentrations of trace metals (Mo is weakly anomalous) and disseminated fine-grained silica. Sulfidation was a key to ore formation, but details of reactions are not known (Nash, 1988). Pre-ore sulfides in dolomite and black shale may have been important, or biogenic reduction of sulfate and the formation of abundant fine-grained marcasite may have occurred at the time of uranium emplacement. I favor reduction by metastable sulfur compounds (sulfite or thiosulfite) as proposed for some sandstone-type uranium deposits (Granger and Warren, 1969; Reynolds and Goldhaber, 1983). The most likely time of ore formation was in the Oligocene when volcanic rocks covered the fault zone. 
The genetic model proposed by Nash (1988) includes a speculative uranium source in Oligocene quartz latite welded tuff containing pumice and glass that overlay the Chester fault zone. Although only thin relicts are preserved, Olson (1983) reconstructs a section of these rocks that would have been several hundred feet thick. The Oligocene tuff would have been highly reactive shortly after deposition and could have released silica and uranium as described by Zielinski (1981). Volcanic rocks within $10 \mathrm{~km}$ of the Pitch Mine are more radioactive today than other rocks, including Precambrian granite. Freshest samples of tuffs contain an average of $10.5 \mathrm{ppm} \mathrm{U}$ and $35 \mathrm{ppm}$ Th, and probably contained more $\mathrm{U}$ when they were deposited.

The paleohydrologic setting of ore formation at the Pitch Mine is well-defined from the work of Olson (1983). In the Oligocene, the deposit area lay beneath a trough filled by volcanic rocks and about $600 \mathrm{~m}$ above the Marshall Creek paleovalley to the south. Intermittent lakes might have been filled with tuffaceous rocks. Groundwater in the mine area flowed southward along the Chester fault zone, beneath a cover of volcanic rocks, toward Marshall Creek paleovalley. Volcanism in the area would have heated groundwater to as much as $50-75^{\circ} \mathrm{C}$. A few hundred meters below the surface, in the permeable Chester fault zone, groundwater would have been oxygenated, or partially oxygenated, providing excellent conditions for uranium transport. The laterally or downward moving waters would have deposited uranium and silica minerals where they encountered structural traps with reducing conditions.

Major fault and breccia zones like that of the Chester fault at the Pitch Mine have the potential to carry large uranium resources. Knowing the ore controls, and announced reserves for the Pitch deposit (previously discussed), a speculative resource can be calculated from the geometry of the breccia zone, about $100 \mathrm{~m}$ wide, 200 or more $\mathrm{m}$ deep, and at least $3 \mathrm{~km}$ long (Nash, 1988). Assuming that there should be high grades (about 0.2 percent $\mathrm{U}_{3} \mathrm{O}_{8}$ ) in dolomite fault slivers, and lower grades ( 0.02 to 0.10 percent $\mathrm{U}_{3} \mathrm{O}_{8}$ ) in slightly fractured granite, sandstone, and shale, potential resources could be 10,000-30,000 tonnes $\mathrm{U}_{3} \mathrm{O}_{8}$, only part of which would be economic to recover.

\section{Midnite Mine, Washington}

Production at the Midnite Mine from 1955 to 1982 made it the second largest hardrock uranium mine in the United States, with a total of $6,580 \mathrm{t} \mathrm{U}_{3} \mathrm{O}_{8}$ at 0.16 to 0.18 percent $\mathrm{U}_{3} \mathrm{O}_{8}$ (Chenoweth, 1991). Reduced and oxidized uranium minerals occur disseminated and in thin veinlets in Proterozoic phyllites and calc-silicate hornfels adjacent to a Late Cretaceous porphyritic quartz monzonite (Nash and Lehrman, 1975; Ludwig and others, 1981). Highest grades and thickest zones of ore are associated with depressions in the roof of the pluton (fig. 12). Pyrite and marcasite are abundant and commonly have colloform texture where associated with uraninite and coffinite. 

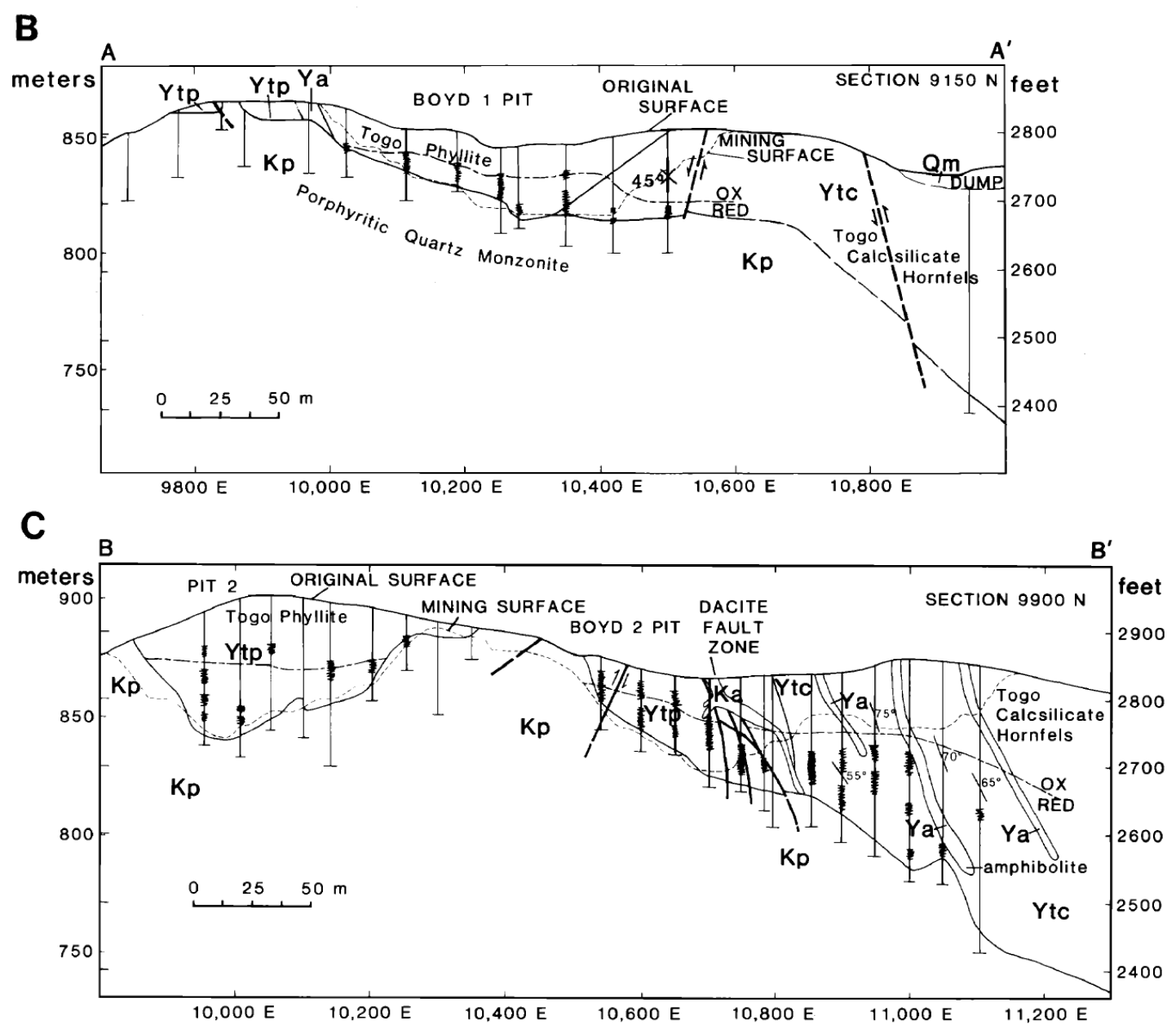

Figure 12. Cross sections of the Midnite Mine showing the location of uranium zones in the contact zone above a pluton (Kp), and apparent ponding of $U$ in depressions. (fig. 1B-C of Ludwig and others, 1981; @Society of Economic Geologists). Ore intercepts are shown as thick lines on drill holes.

Genesis of this important deposit may be related to volcanism, and multiple hypotheses have been proposed. Geochronologic studies ( $\mathrm{Pb}-\mathrm{U}$ isotopes in ore, fission track in apatite) demonstrate that the ores formed at $51 \mathrm{Ma}$, or about $24 \mathrm{~m} . \mathrm{y}$. after intrusion of a porphyritic stock (Ludwig and others, 1981). That time of ore formation coincides with emplacement of flows, tuff, and dikes correlated with the Sanpoil Volcanics of Pearson and Obradovich (1977). The stock is clearly enriched in uranium, about $17 \mathrm{ppm}$, making it the likely uranium source. The uranium is in the matrix of the porphyry rather than in refractory accessory phases. Abundant marcasite, weak alteration, and $51 \mathrm{Ma}$ age are consistent with a warm, weakly oxidizing, near-surface flow of groundwater through the pluton and its roof zone (Ludwig and others, 1981). Abundant marcasite suggests formation from metastable sulfur species, which are 
powerful reductants (Reynolds and Goldhaber, 1983). Some uranium could have come from the local volcanics, although this is less likely than the stock, because the volcanics are intermediate in composition and have not been demonstrated to be unusually radioactive. The temperature of ore formation at the Midnite was modestly warm, based on the failure to reset fission tracks in apatite in the porphyritic stock, which indicates temperatures were less than about $100^{\circ} \mathrm{C}$, and the thermal event was short-lived (Ludwig and others, 1981).

The volcanic environment in the Midnite Mine area has not been studied in detail, but many parameters are clear. The deposit formed during a time of tectonic extension, when the famous Republic graben and associated epithermal ore deposits (Full and Grantham, 1968) formed, and an east-west trough in the mine area was filled with volcanic rocks of intermediate composition (Becraft and Weis, 1963; Pearson and Obradovich, 1977; Moye, 1982).

\section{Apex Mine, Austin District, Nevada}

The largest uranium producer in Nevada, the Apex Mine near Austin, is arguably volcanogenic. Recorded production from 1954 to 1966 was $50 \mathrm{t}$ of $\mathrm{U}_{3} \mathrm{O}_{8}$ at 0.25 percent $\mathrm{U}_{3} \mathrm{O}_{8}$ (Chenoweth, 1991), despite the lack of a uranium mill in Nevada. This deposit and several others nearby were found in 1953 (Garside, 1973; Shawe and others, 1991). Deposits of autunite and torbernite were identified and partly mined underground in the 1950s. Extensive drilling in the late 1970s probed deeper structures and some zones were test-mined (Plut, 1979). The deposits occur along the faulted contact of Jurassic quartz monzonite with Cambrian quartzite and shale. Highest uranium grades are in brecciated quartzite, quartz monzonite, and strongly sericitized aplite dikes. The early mining was in oxidized rocks above the modern water table; much of the mined ore may have accumulated along an oxidation-reduction boundary or paleo-water table (Plut, 1979). The presence or former presence of black, quadrivalent $U$ minerals remains uncertain; Plut (1979) did not report the black phases, but in 1997 I observed what appeared to be black uranium minerals, with sulfides, in some very radioactive stockpiles of uncertain mining date and source. My calibrated scintillometer suggested grades higher than 0.2 percent $\mathrm{U}_{3} \mathrm{O}_{8}$, but no mineralogical or chemical analyses were made. Hydrogeochemical studies (Nash, 2005) focused on dump compositions and the tendency to create acidic drainage from oxidizing sulfide minerals; leach tests on dump samples showed they released high concentrations of $\mathrm{U}, \mathrm{As}, \mathrm{Cu}$, and $\mathrm{Se}$. The ore zone has undergone multiple periods of faulting and alteration, including relatively recent Basin-range faulting and tilting. Jurassic granitic rocks in the area are not notably radioactive and the freshest samples contain normal amounts of uranium and thorium, whereas Tertiary volcanic tuffs and flows have high radioactivity and uranium contents in excess of $10 \mathrm{ppm}$ (Nash, unpublished data, 1977).

The Apex deposits have much in common with those at the Midnite Mine and similar questions of genesis. The Apex deposit could have formed by hydrothermal processes associated with Jurassic intrusions, or it could have formed in the Tertiary during alteration of overlying volcanic rocks. At either time, the faulted intrusive contact would have been important for structural permeability. The amount, kinds, and 
distribution of primary sulfide minerals are not known, but today most of the alteration and uranium minerals are oxidized. This is to be expected in the uplifted range, near the range front fault zone. The Basin-range extension and range tilting would have promoted groundwater flow from volcanic rocks into the contact zone, adding or enriching uranium. Or, uplift and change in groundwater flow and composition could have destroyed part of these deposits. Preservation or destruction of volcanogenic uranium deposits by post-ore tectonism and erosion will be discussed in a later section.

\section{Arlit, Niger: Deposits in Volcaniclastic Sandstone}

Speculatively, the large and very productive deposits of Niger, near Arlit, can be considered to be volcanogenic in the sense of having an essential relationship to volcanogenic processes. These deposits have long been considered to be of sandstonetype associated with organic material in continental sandstones (Cazoulat, 1985). There are more than 25 deposits that are large, in the range of 5,000 to more than 100,000 $\mathrm{t}$ $\mathrm{U}_{3} \mathrm{O}_{8}$ and low to medium grade ( 0.1 to 0.5 percent $\mathrm{U}_{3} \mathrm{O}_{8}$ ) (IAEA, 2008). However, there are a number of features that suggest they are not conventional sandstone deposits. The deposits occur in sedimentary units of Mississippian to Cretaceous age within one district. There is a spatial association to both the major Arlit fault and lesser cross faults. The Arlit fault probably was active during sedimentation in the Tim Mersoi basin. Geochemical associations of trace elements, notably very high concentrations of $\mathrm{Zr}$ in uraninite, are similar to those described here for volcanogenic deposits. Fluid-inclusion studies suggest the role of brines and temperatures of $85-175^{\circ} \mathrm{C}$ (Pagel and others, 2005); a similar thermal history is indicated by studies of organic matter. Descriptions and detailed geochemical studies are surprisingly lacking for these important deposits, but new thinking by researchers in France (Pagel and others, 2005; Cuney and Kyser, 2009) favors ore formation by heated fluids that circulated along fracture systems, leached uranium from the well-known altered tuffaceous beds, and deposited $U$ in reducing carbonaceous zones in permeable sandstone channels. Alternatively, some deposits could be redistributed from early-formed pene-syngenetic ores. Some researchers (for example, Cuney and Kyser, 2009; Cuney, 2009) envision a spectrum of deposits from sandstonetype, to "teconic-lithologic type" strongly controlled by faults, to volcanic- and unconformity-type deposits, with a common relation to oxidizing hydrothermal processes. A key part of the geologic framework at Arlit is the episodic post-orogenic alkaline intrusions and ring dikes that fed volcanoes from about 480 to $145 \mathrm{Ma}$; these alkalic rocks are famous for their enrichment in lithophile elements including uranium (Bowden, 1985). The Arlit District has some of the largest resources in the world: production through 2007 was about 110,000 tonnes $\mathrm{U}_{3} \mathrm{O}_{8}$; resources remaining are about 97,000 tonnes of $\mathrm{U}_{3} \mathrm{O}_{8}$ plus 192,000 tonnes $\mathrm{U}_{3} \mathrm{O}_{8}$ in the Imouraren deposit, which will be the second largest uranium mine in the world after 2012 (Areva, 2009).

\section{Metamorphosed Volcanogenic Deposits}

Several uranium deposits in metamorphic rocks display features suggestive of an initial stage of uranium enrichment in volcanic complexes. Best known deposits are in Labrador, Canada, and northern Sweden. Diagnostic textures survive metamorphism in northern and eastern Canada (Baker Lake Basin and Makkovik Fold Belt) to support concepts of syn-volcanic uranium processes in Precambrian rhyolites (Gandhi, 1978; 
Curtis, 1981; Cuney and Kyser, 2009). The Michelin deposit in Central Labrador is reported to contain about $17,235,000 \mathrm{lbs}(7,818 \mathrm{t}) \mathrm{U}_{3} \mathrm{O}_{8}$ at an average grade of 0.109 percent $\mathrm{U}_{3} \mathrm{O}_{8}$ (Curtis, 1981), an important deposit. Recent drilling has expanded the measured and indicated resources to $30,573 \mathrm{t} \mathrm{U}_{3} \mathrm{O}_{8}$ with inferred resources of 16,103 $\mathrm{t}$ $\mathrm{U}_{3} \mathrm{O}_{8}$; the average grade for the proposed underground mine is 0.12 percent $\mathrm{U}_{3} \mathrm{O}_{8}$ and 0.07 percent $\mathrm{U}_{3} \mathrm{O}_{8}$ for the proposed open pit. (Aurora Energy Resources Inc., Vancouver, BC, Canada, press release Feb. 20, 2008). Several deposits in northern Sweden are tabular, within ignimbrite and volcaniclastic rocks, and thought to be remobilized at about $1,750 \mathrm{Ma}$. The Swedish deposits have grades of only 0.03 to 0.07 percent $\mathrm{U}_{3} \mathrm{O}_{8}$, and resources of about 700 to $4,000 \mathrm{t} \mathrm{U}_{3} \mathrm{O}_{8}$.

Metamorphosed deposits will not be considered further because it is not clear how much metamorphic processes enrich or disperse primary uranium concentrations. The grade and tonnage of these deposits fits adequately within the scatter of values for other volcanic settings, and metamorphism probably is less influential in changing deposit geochemistry than supergene processes. The metamorphosed deposits retain geochemical signatures, such as high Mo-Th-Zr concentrations, recognized in pristine volcanogenic deposits (Cuney and Kyser, 2009).

\section{Genesis of Uranium Deposits: Concepts for Source, Transport, and Deposition}

\section{Source Mechanisms and Concepts}

\section{Uranium in Magmas and Magmatic-Hydrothermal Fluids}

There is abundant evidence for uranium enrichment in silicic magmas, but is there evidence for uranium enrichment in magmatic-hydrothermal fluids? Are there magmatichydrothermal uranium deposits? The short answer to both questions is yes, but these magmatic uranium deposits are rare and tend to be small. The theoretical framework for these questions, discussed by Cuney and Kyser (2009), is too complex to discuss here, but two aspects can be summarized regarding a) volatile content of very shallow magmas, and $b$ ) the behavior of $U$ in evolving magmas. The water content of shallow rhyolite intrusions and extrusions is relatively low compared to other igneous rocks, as reflected in the low content of hydrous phases like biotite and the high viscosity of these magmas (Best and Christiansen, 2001). At very shallow depths (less than $1 \mathrm{~km}$ ), there is not much water to exsolve into an aqueous phase (magmatic hydrothermal fluid). Indeed, according to many stable isotopic studies, most of the water in these rocks is meteoric, flowing into the intrusion rather than outward (Sillitoe and Bonham, 1984; Taylor, 1997).

The experimental, geochemical, and field evidence seems apparent that uranium remains in the melt relative to exsolved magmatic fluids; this behavior is fundamentally different from metals such as $\mathrm{Cu}$ and Mo that escape in volatile-rich fluids that have the potential to form ore deposits such as the porphyry type. Experiments demonstrate that even under unusually high volatile concentrations, most $U$ stays in the melt phase (Keppler and Wylie, 1991; Peiffert and others, 1996). The experiments show that 
increases in oxygen fugacity and halide molality produced higher $\mathrm{U}$ concentrations in both the melt and fluid phase, but concentrations of $U$ in the melt phase were about 1,000-times that of the fluid. Petrologic studies document that $U$ resides in accessory phases or in glass in U-rich magmatic rocks, and is not concentrated in postcrystallization hydrothermal veinlets. The abundant experimental and petrologic evidence for the concentration and release of base metals associated with chloride-rich magmatic fluids (Burnham, 1997; Candela, 1997; Seedorff and others, 2005) does not apply to uranium. The specific case of uranium veins, reviewed next, illustrates this point.

Diverse ore genesis theories, ranging from magmatic to supergene, have been proposed for intra-granitic vein deposits of uranium (Cuney and Kyser, 2009). Detailed geochemical and geologic studies have established that uranium-vein deposits are indeed hydrothermal, but were formed by leaching and remobilizing uranium millions of years after plutonic crystallization (Cuney, 1978; Poty and others, 1986; Cuney and Kyser, 2009). Such multi-stage processes take place when a later geothermal system is superimposed on the granitic rocks; in some localities the ore-forming stage occurs after the magmatic U-bearing phases have become metamict and amenable to dissolution. Likewise, multi-stage processes have been identified for uranium deposits in rhyolites at Pena Blanca (George-Aniel and others, 1991) where vapor-phase alteration is required to make the rhyolite "fertile" for later hydrothermal redistribution and concentration of uranium.

Uranium with its high charge and multiple oxidation states, does not behave like most metals in magmatic-hydrothermal processes. Thus, some concepts from seemingly similar ore systems can be misleading. Multiple stages of enrichment and transport, sometimes over millions of years, are required to move $\mathrm{U}$ from volcanic magmas to ore zones. Geologic processes other than those that form magmatic-hydrothermal metal deposits seem to be required to form significant $\mathrm{U}$ deposits.

\section{Rhyolite Magmatism}

Both uranium and felsic magmas must come from the crust, a conclusion based on heat flow and petrochemical studies. Advances in geochemical and isotopic analysis have allowed researchers to specify the time-space-depth relations of rhyolite magmas and place them in a tectonic framework (John, 2001; Best and Christiansen, 2001); these advances are as relevant to uranium deposits as they are for epithermal ore deposits. John (2001) and colleagues working on Tertiary gold systems in the Great Basin recognize two classes of magmas: a) a bimodal suite having mafic (basalt) and rhyolite members, and b) a western andesite assemblage characterized by extensive hydrothermal alteration and base-metal enrichment along with gold-silver. The western andesite assemblage is generally not enriched in U or a host for U-deposits, so this suite will not be discussed further. What is distinctive about the bimodal (rhyolite) magmatism? Much is known about the petrotectonics of U-rich magmas of the Andes, Africa, and France, but we will focus on the Great Basin, United States. 
Extension-related tectonics that are characteristic of the Great Basin commenced in the late Eocene, caused by rifting associated with subduction of the Farallon plate under North America (John, 2001, references therein). The western part of the Great Basin received andesitic volcanism, whereas to the northeast there was a different style, possibly related to the Yellowstone hot spot. A mantle plume or upwelling mantle may have caused partially melted crustal rocks (fig. 13). Extension allowed mafic (basaltic) magma to rise rapidly through the crust to form flows and shield volcanoes. However, in places the basalt underplated the crust, melting it and creating rhyolitic magma at variable depths. Magma chambers at mid-crustal depths tended to erupt as ash-flow tuffs and form calderas. Diapirs of viscous, water-poor, rhyolite magma also tended to rise to the surface as rhyolite domes. The rhyolite magmas were enriched in $U$ as part of the partialmelting process discussed below.

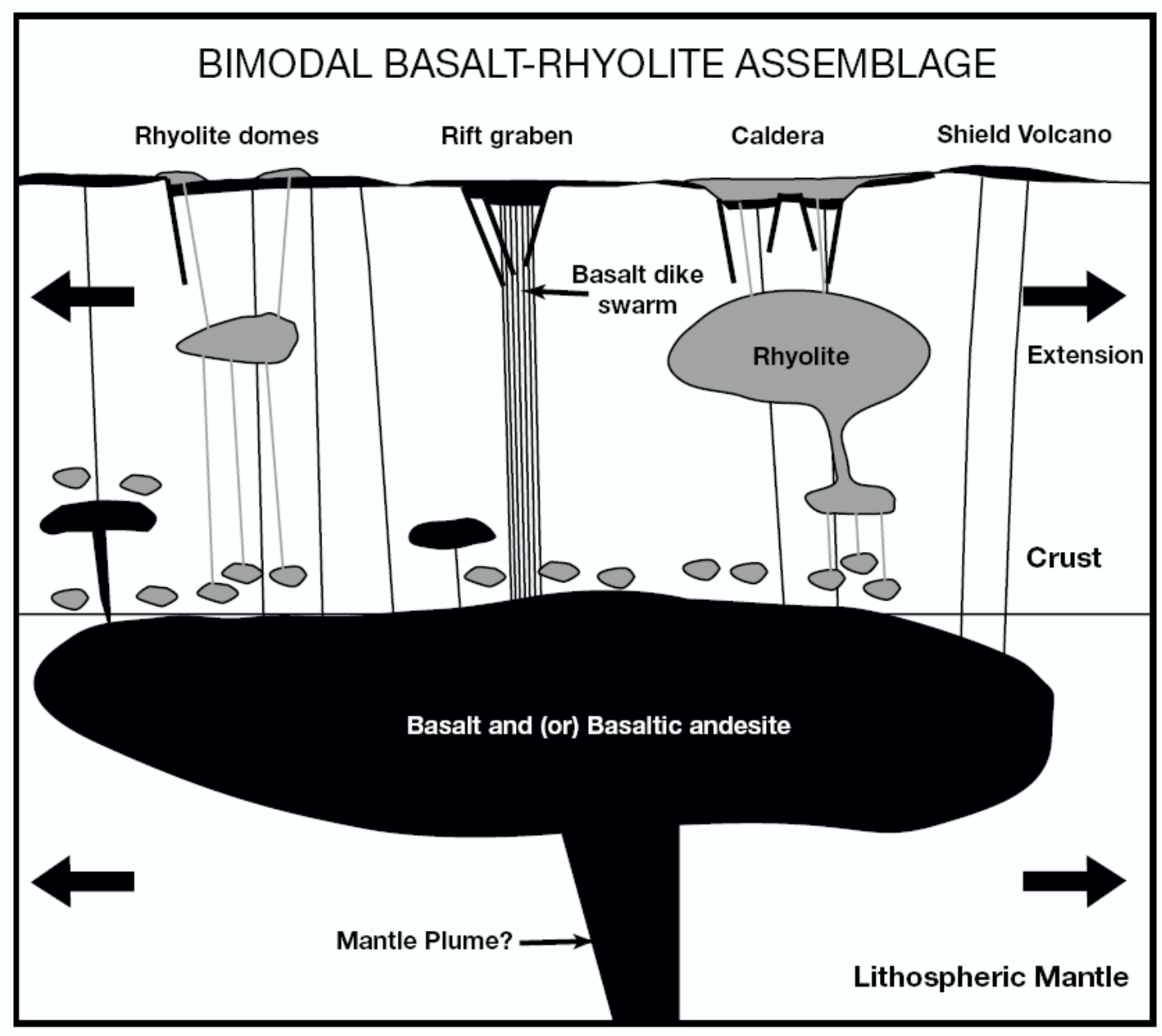

Figure 13. Cartoon describing the magmatic-tectonic setting of bimodal basaltrhyolite magmatism "Upwelling of the athenospheric mantle into the lithosphere, possibly due to impingement of a mantle plume, led to partial melting of the subduction-modified mantle. Small amounts of partial melting of the base of the crust resulted from basalt underplating and formed reduced, water-poor rhyolite melts." (fig. 9 of John, 2001; OSociety of Economic Geologists). 
The Cenozoic bimodal assemblage (that includes rhyolite) is characterized by low oxygen and sulfur fugacities, and low water content, relative to the western andesite assemblage (John, 2001). These parameters are generally agreed to be important for the genesis of hydrothermal metal deposits, but they may not be important for volcanogenic uranium systems. More understanding is needed on how the concentration and distribution of $U$ in rhyolites is related to tectonic setting, parent material, and volatile constituents. The increased knowledge would result in a better discrimination of rhyolites that would contain sufficient uranium in the proper phases to favor redistribution into economic deposits. The fundamental questions regarding $U$ content and oxygen fugacities and water content of rhyolites can not be answered from available geochemical studies of natural samples because the required petrological studies are rarely made as part of uranium studies. Experimental studies are useful, as discussed previously. Also, is there a relation of uranium behavior to size of magma chambers and eruption style? Are large-volume homogenous tuffs (for example, Christiansen, 2005) less fertile than the zoned tuff sequences erupted from zoned magma chambers (Hildreth, 1979); the latter attain more extreme compositions, as at McDermitt (Rytuba and Conrad, 1981; described earlier). A few chemical analyses of large volume tuffs reported by Christiansen and co-workers suggest $U$ and Th concentrations are not unusual.

A special variety of rhyolite, alkali or topaz rhyolite is famous for its enrichment in many lithophile or fluorophile elements including U (Burt and others, 1982;

Christiansen and others, 1986). These highly fractionated magmas occur at the top of felsic magma chambers where volatile elements $(\mathrm{F}, \mathrm{Cl}$, water) become concentrated. If the top of the chamber is tapped by a vent, the resulting release of magma and fluid may emplace a dike or produce an ash flow, composed of topaz-bearing rhyolite. Because the topaz rhyolite magmas are rich in volatiles, they have the potential to create hydrothermal deposits of U, or other fluorophile elements such as Be or Mo (Burt and others, 1982). The topaz rhyolite magmas are postulated to be transitional to the even more fractionated and volatile-rich magmas that create Climax-type molybdenum deposits. Topaz rhyolite magmas seem to form only small hydrothermal uranium deposits (Burt and others, 1982). However, erupted topaz rhyolites may be favorable U source rocks amenable to leaching by later meteoric water. Distribution of the topaz rhyolites across the western United States is shown in figure 14. 


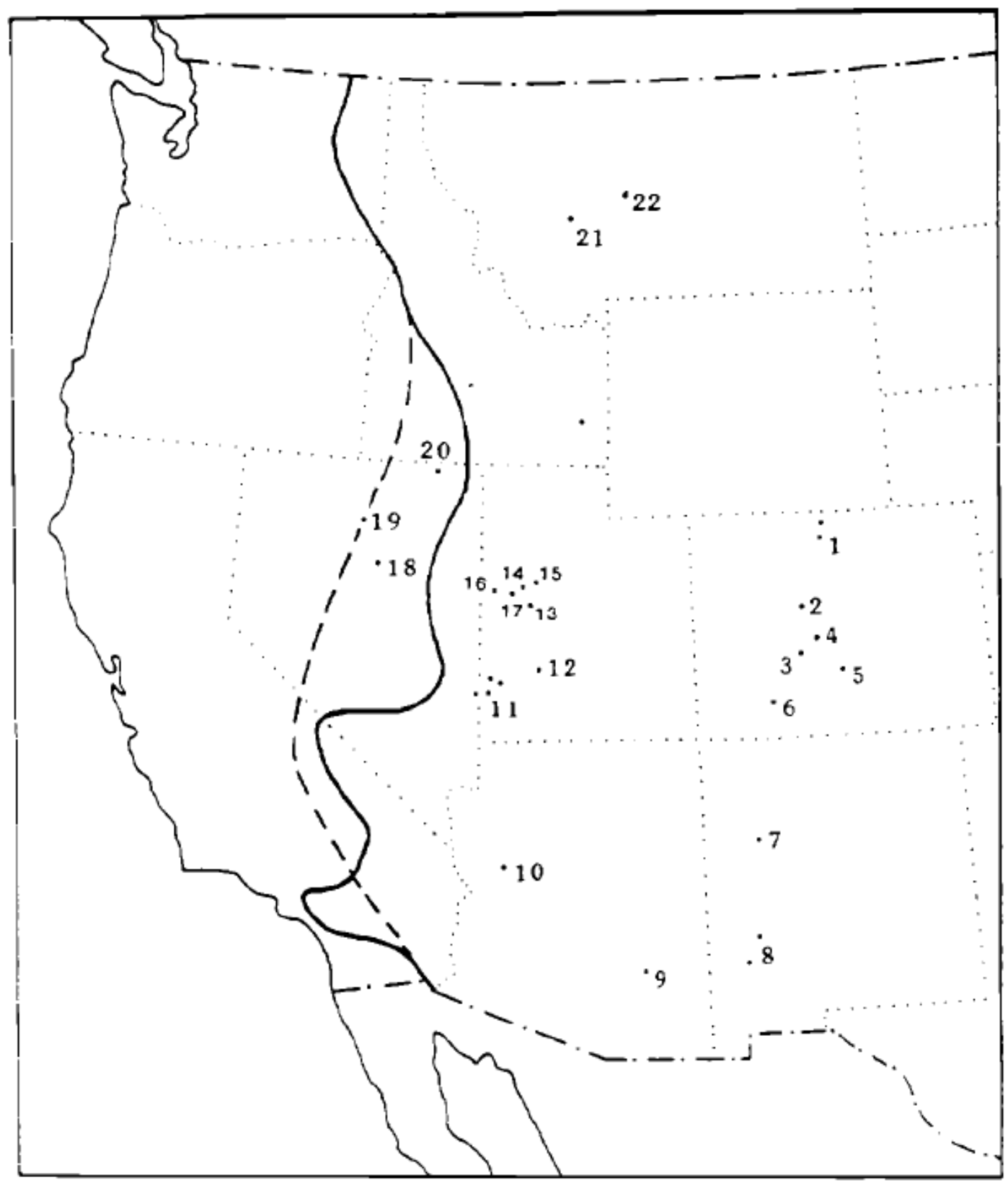

Figure 14. Distribution of topaz rhyolites in the western United States. The solid and dashed lines are estimates of the western limit of Precambrian basement rocks. (fig. 1 of Burt and others, 1982, AAPG@ 1982, reprinted by permission of the AAPG whose permission is required for further use.) 
Further research is needed on the role of crustal protolith composition on partial melt (rhyolite) trace-metal composition. After reviewing and evaluating numerous petrochemical parameters and ore-deposit associations, John (2001) concluded that variations in types of basement rocks are not evident in the ore types he considered. A significant point in support of this conclusion is the observation that the initial strontium isotope isopleth crosses the trends of volcanic assemblages and ore types. However, some uranium researchers have proposed that many $U$ trends in rock and ore concentrations are inherited from a prior stage of uranium enrichment, perhaps in Precambrian rocks in general or Paleoproterozoic rocks in particular (Nash and others, 1981; Simpson and Hurdley, 1988). Prior enrichment may stem from growth of juvenile continental crust and supercontinents from about 3.0 to $1.7 \mathrm{Ga}$, which favored the creation and preservation of certain kinds of gold, metal, and U deposits (Groves and others, 2005; Pehrsson and others, 2007). Thus, the observation that $\mathrm{F}$ in granitic and volcanic rocks varies across the Great Basin (Burt and others, 1982; Christiansen and Lee, 1986) may reflect different uranium content of basement rocks: the lower amounts of $F$ in the western Great Basin may be related to the lack of Precambrian basement in that area. Patterns in the variation in the U content of igneous zircons (Silver, 1976) have also been interpreted to support the variable uranium contents of basement rocks.

\section{Petrochemistry of Uranium in Volcanic Rocks}

The distribution of uranium in volcanic rocks is fairly well understood, thanks largely to important analytical advances in the 1970s. Development of delayed-neutron activation analysis allowed high-precision analysis for $U$ and $T h$ to the $1 \mathrm{ppm}$ level (Millard, 1976). Also, an improved method of uranium "mapping" in thin sections using fission tracks (Fleischer and others, 1966) permitted detection of uranium-bearing sites to within about 10 microns and could be calibrated to give quantitative results. These methods were applied to refine the original concept of volcanic rocks and volcaniclastics as a source of uranium (Waters and Granger, 1953). Recent advances in electron-beam and ion-beam analysis, with smaller beam diameter and lower detection limits, permit analysis of uranium contents of small accessory minerals, such as zircon and allanite, and thin coatings of uraninite on iron-oxide minerals (reviewed by Cuney and Kyser, 2009).

Studies of many volcanic systems in the western United States (Zielinski, 1978; Zielinski, 1985; Castor and Henry, 2000) show an association of high $U$ and Th concentrations with silicic volcanic rocks, generally classified as "rhyolite". High U concentrations exceed 9 ppm, with some exceeding 20 ppm; high Th concentrations are above $20 \mathrm{ppm}$, and some more than $40 \mathrm{ppm}$. Topaz rhyolites have the highest concentrations of $U$ at some places (15-40 ppm U; Burt and others, 1982). Global studies (Cuney and Kyser, 2009) point to high U concentrations in peralkaline volcanic rocks, but high values are also found in alkali rhyolites, metaluminous rhyolites, and some calc-alkaline tuffs (Castor and Henry, 2000). The ratio Th:U generally ranges from about 2 to 3 in fresh rhyolites. Many researchers (see citations above) note that alteration changes U content significantly, and that reported concentrations vary as much with alteration state as with composition. Reasoning that Th is immobile under most alteration conditions, variations in Th:U have been interpreted as a measure of enrichment or loss of U (Stuckless, 1980; Castor and Henry, 2000). Uranium concentrations in regional 
databases (discussed later) should be considered to be minimum estimates of original concentrations.

Volcanic rock compositions (especially ash-fall tuffs) are well understood from the perspective of zoned magma chambers (Hildreth, 1979; Rytuba and Conrad, 1981). The upper part of magma chambers becomes enriched in silica (rhyolite) and incompatible trace elements such as $\mathrm{Ba}, \mathrm{Cs}, \mathrm{Rb}, \mathrm{Sr}, \mathrm{Zr}, \mathrm{U}$, Th, and F. Eruption from the upper part of the magma chamber then produces tuff that is enriched in $\mathrm{U}$ and $\mathrm{Th}$, whereas eruption from deeper parts of the chamber produces a more mafic volcanic rock that is lower in alkalis, U, and Th. At McDermitt, five large-volume, caldera-forming, high-silica rhyolite tuffs are enriched in Th, Zr, and 7 to $10 \mathrm{ppm} \mathrm{U}$ (Rytuba and Conrad, 1981). Likewise, post-caldera eruptions produced alkali rhyolite (topaz bearing) at Spor Mountain that are enriched in Be, F, Th and U (10-30 ppm) (Lindsey, 1981; 1982).

Alkaline or peralkaline compositions have been highlighted at several productive uranium districts, such as McDermitt, Pocas de Caldas, and Arlit, and the petrochemistry of these volcanic complexes have been investigated in detail because they are economically significant and geochemically exotic. Cuney explains the behavior of $U$ and Th in differentiation of alkaline magmas (Cuney and Kyser, 2009, Chapter 4), which is pertinent to the volcanic phases. But this is not the only explanation for uranium in magmas. Castor and Henry (2000) point out that many compositions are enriched in U. Further, Leroy and George-Aniel (1992) show that crystallization style (texture) is important: uranium residing in glassy volcanic matrix is amenable to leaching during alteration, as discussed next.

\section{Release of Uranium}

Release of uranium from rhyolite intrusions, flows, and tuffs is related to alteration processes that range from hot (about $\left.400^{\circ} \mathrm{C}\right)$ to conditions typical of the earth's surface (vapor phase to weathering). Micro-scale movement of uranium from primary phases to oxide coatings during vapor phase alteration (Leroy and others, 1987) is a key step to making the contained U accessible to passing hydrothermal or supergene fluids. This is similar to processes considered to cause U-rich granitic rocks to be "fertile" for formation of uranium deposits (for example, Poty and others, 1986).

Experimental leaching of glassy volcanic rock samples under controlled hydrothermal conditions with alkaline solutions (Zielinski, 1981) demonstrates the preferential extraction of silica, $\mathrm{Li}, \mathrm{K}$, and $\mathrm{U}$, with up to 33 percent of total $\mathrm{U}$ extracted in experiments lasting just 10 hours. Reactions proceeded faster at higher temperatures. The roles of solution composition and time are discussed by Zielinski. The experiments confirm what geochemists have deduced from natural samples: in many situations $U$ is easily leached from volcanic rocks. Most $U$ in extrusive rocks and volcaniclastic rocks resides in glass (Zielinksi, 1981; Leroy and George-Aniel, 1992; Cuney and Kyser, 2009), thus the key to releasing $U$ is alteration of glass. In many environments this is rapid, but there are situations in which glass remains remarkably stable. Meteoric water flow determines the alteration process of volcanic detritus in both the piedmont and in intermontane basins (Sheppard and Hay, 2001). Zeolite forms in both closed systems 
(lacustrine basins in which the reacting pore fluid does not leave (Langella and others, 2001; Surdam, 1977), and in open systems (where meteoric waters flow downward and laterally through strata and eventually out of the basin (Hay and Sheppard, 1977; Sheppard and Hay, 2001)). In open systems, which may resemble volcanic centers outside calderas, fluids presumably leave, but their composition including uranium content is unknown. Hydrolysis reactions involving glass create alkaline to very alkaline brines that become very rich in alkali metals, and these brines could transport $\mathrm{U}$. Alkalinity, determined by carbonate-ion equilibria, influences mineral stabilities (Hardie and Eugster, 1970), and should be important in low-temperature U transport. Climate, tectonic setting, and hydrology are significant in the saline or alkaline lake and brine evolution (Surdam, 1977), and should be included in concepts for U release and mobilization.

Release of $\mathrm{U}$ from vitric volcanic rocks during weathering or hydrothermal alteration has been established by experimental and petrochemical studies. These results nonetheless do not require that the released $\mathrm{U}$ be transported in groundwater. Careful studies of some localities in Utah (Zielinski and others, 1980) and Texas (Henry and Duex, 1981) have shown that released U may be adsorbed by secondary amorphous FeMn-oxyhydroxides and other micro-traps in the source beds. In addition, the relatively stagnant hydrologic environment that promotes zeolitic alteration does not favor uranium mass transfer (Zielinski and others, 1980). Research on fluid flow and metal transport in shale and volcanogenic base-metal systems suggests that transport of uranium-rich fluids can be driven by compaction, dewatering, and several styles of gravity-, thermal-, and tectonic-driven basin flow (Hanor, 1979; Gustafson and Williams, 1981; Nash and Hahn, 1989; Garven and Raffensperger, 1997; and others). Tectonism and tilting shortly after volcanism and sedimentations, as in the Eocene of the Great Basin, would change groundwater hydrology and would logically induce flow of previously stagnant pore fluids provided that the units have sufficient permeability. The amount of groundwater recharge during and after tectonism would contribute to the rate and extent of uranium transfer. Finally, we can speculate that for long-distance transport, major flow would be limited to aquifers, such as sandy strata or fractured massive rock units, rather than in clay-rich altered vitric tuffs and volcaniclastics.

\section{Transport Mechanisms and Concepts}

\section{Uranium Transport}

Transport of relatively high dissolved concentrations of uranium to sites of possible ore formation requires oxidizing water composition, and favorable hydrology. Chemically, it is well known that uranium is mobile under oxidizing conditions in which $\mathrm{U}^{+6}$ species are stable and this causes the well-known separation of $\mathrm{U}$ from Th (Hostetler and Garrels, 1962). The other crucial factor is a paleohydrologic setting that favors large flow volumes and focuses flow into favorable environments for deposition. Also, fluid mixing is required to explain some precipitation reactions, so we must consider environments favorable for production of fluids with differing physical and chemical properties. 
Over the past 60 years many researchers have calculated, or postulated, the efficiency of several ligands for the transport of $\mathrm{U}^{+6}$. Carbonate complexes have been advocated for neutral to alkaline conditions and low temperatures (Hostetler and Garrels, 1962; Langmuir, 1978). Fluoride forms stable complexes with $\mathrm{U}^{+6}$ and possibly $\mathrm{U}^{+4}$ at low pH (Romberger, 1984), if there is sufficient F in the environment. More recently, chloride complexes have been proposed for high salinity fluids (Komninou and Sverjensky, 1996; Cuney and Kyser, 2009), which seems appropriate for basin brines and some volcanic systems. As documented and modeled for Creede (Hayba, 1997), volcanic systems can have fluids of vastly different composition. High-salinity fluid inclusions are reported from Pocos de Caldos (Cathles and Shea, 1992), but fluid inclusions in other deposits have low salinities (less than about 10 wt percent $\mathrm{NaCl}$ equivalent). Fluidinclusion data are sparse for volcanogenic deposits, but recent studies of several ore stages at the Streltsovkoye-Antei deposit indicate primary pitchblende deposition was at temperatures up to " $350-460^{\circ} \mathrm{C}$ from Na-Cl- $\left(\mathrm{HCO}_{3}\right)$ fluids" (Cuney and Kyser, 2009). In summary, several ligands are effective in the oxidizing environment of shallow volcanic systems and adequate to do the transport; carbonate and chloride are most likely to be in this environment, and there is no doubting the efficacy of fluoride where it is present. Most of these complexes become weaker with cooling or loss of pressure or boiling, processes that are likely in volcanic environments. Increase of acidity also can weaken many complexes, likely during mixing, as discussed later.

The hexavalent state of uranium is easily attained in aerobic weathering zones, but at greater depth conditions on the oxidizing side of the hematite/magnetite boundary are not commonly attained. Oxidation required to form uranyl ion is limited by the low solubility of atmospheric oxygen in groundwater (Granger and Warren, 1969). In sedimentary basins, high sulfate concentrations, especially arising from evaporite beds, provide another oxidation mechanism (Sverjensky, 1987). Reaction of meteoric water or brine with hematite and anhydrite lowers $\mathrm{pH}$ and raises oxygen fugacity. Playa lake deposits adjacent to, or below, volcanic rocks, as in the moat sediments at Creede (Hayba, 1997) may serve as a source of oxidized fluids, sulfate, and chloride — all favorable for uranium leaching and transport. The well known association of uranium deposits with red-bed sequences could be caused by anhydrite interbeds or cements, or related to ferric iron, a known oxidant. The empirical evidence for a spatial association of uranium deposits to strata containing evaporites was reviewed by Nash and others (1981). Further work on this association is needed, including rates of reactions, as the kinetics of sulfate reactions are known to be sluggish at temperatures below about $200^{\circ} \mathrm{C}(\mathrm{G}$. Breit, written commun., 2009).

\section{Thorium Transport}

Many of the volcanic rocks, especially alkaline or peralkaline varieties, associated with uranium deposits have elevated thorium concentrations (30 to $80 \mathrm{ppm}$ ). However, the uranium deposits themselves generally show no enrichment in thorium, according to the existing scant data. There are exceptions: the Rexspar deposit contains U-Th phases and more Th than U, and the U-Be mineralization at Spor Mountain contains up to about $80 \mathrm{ppm}$ Th. These high Th concentrations are limited to rocks that contain high fluorine concentrations. Calculations and experimental data confirm that the only way to transport 
significant amounts of Th in hydrothermal solutions is by $\mathrm{F}$ complexes (Romberger, 1999; Gibson and Wood, 1997; Moine and others, 1997; Cuney and Kyser, 2009). Fluidmelt reactions of haplogranite at $750^{\circ} \mathrm{C}$ show that, with high $\mathrm{F}$ concentrations, Th (but not much U) is fractionated into the fluid phase (Keppler and Wylie, 1991; Peiffert and others, 1996); similar experiments with high $\mathrm{Cl}$ concentrations show that $\mathrm{U}$ but not much Th is fractionated into the fluid phase. Unlike several U-complexes, the Th-F complex is insensitive to the oxygen fugacity of the system as there is no change in the oxidation state of Th. Ore analyses and experimental investigations show that volcanogenic uranium deposits will not be enriched in Th except in F-rich systems.

Thus, we are left with an apparent paradox regarding the use of Th in exploration and assessment for $\mathrm{U}$. Elevated Th concentrations ( 20 to $40 \mathrm{ppm}$ ) may be a useful criterion because that probably reflects magmatic differentiation, and probable high $\mathrm{U}$ concentrations (independent of possible U loss in weathering). Redistribution of Th to concentrations greater than about $50 \mathrm{ppm}$, should not be expected in altered or mineralized rocks except where fluorine minerals are abundant.

\section{Hydrology of Volcanic Systems}

Fluid flow in volcanic systems is relatively well understood in the caldera margin and moat areas where caldera-related faults and fractures are known to be a major factor in epithermal precious-metals systems (Sillitoe and Bonham, 1984; Rytuba, 1994; Hayba, 1997; Simmons and others, 2005). Researchers have utilized evidence from geology, mineral assemblages and zonation, fluid inclusions, and stable isotopes to build paleoflow models of hydrothermal systems that formed ore deposits at Creede, Colorado (Barton and others, 1977; Hayba, 1997); Tayolita, Mexico (Simmons, 1991), Pocas de Caldas uranium deposit (Cathles and Shea, 1992) and to build general models of epithermal systems (Henley and Ellis, 1983). In most of these systems, there is a known or inferred shallow intrusion that provides heat (driving force), metals, and some sulfur and water. Most of the water is meteoric, circulating along structures, although in some systems water flow is restricted by aquitards (impermeable tuff or alteration caps) as at Creede (Hayba, 1997; fig. 15).

Climate has been shown to be an important factor in some epithermal systems (Vikre, 1987; Ebert and Rye, 1997; Wallace, 2003). An adequate supply of recharge water to fill conduits and to some degree drive hydrothermal circulation is essential. Not only is water important as the transport media for uranium but it is also a chemical reagent that promotes reactions in glass with the concomitant release of uranium. As a result, sub-aerial volcanics in a dry climate may be potentially reactive, but the lack of sufficient water limits ore-forming processes. 


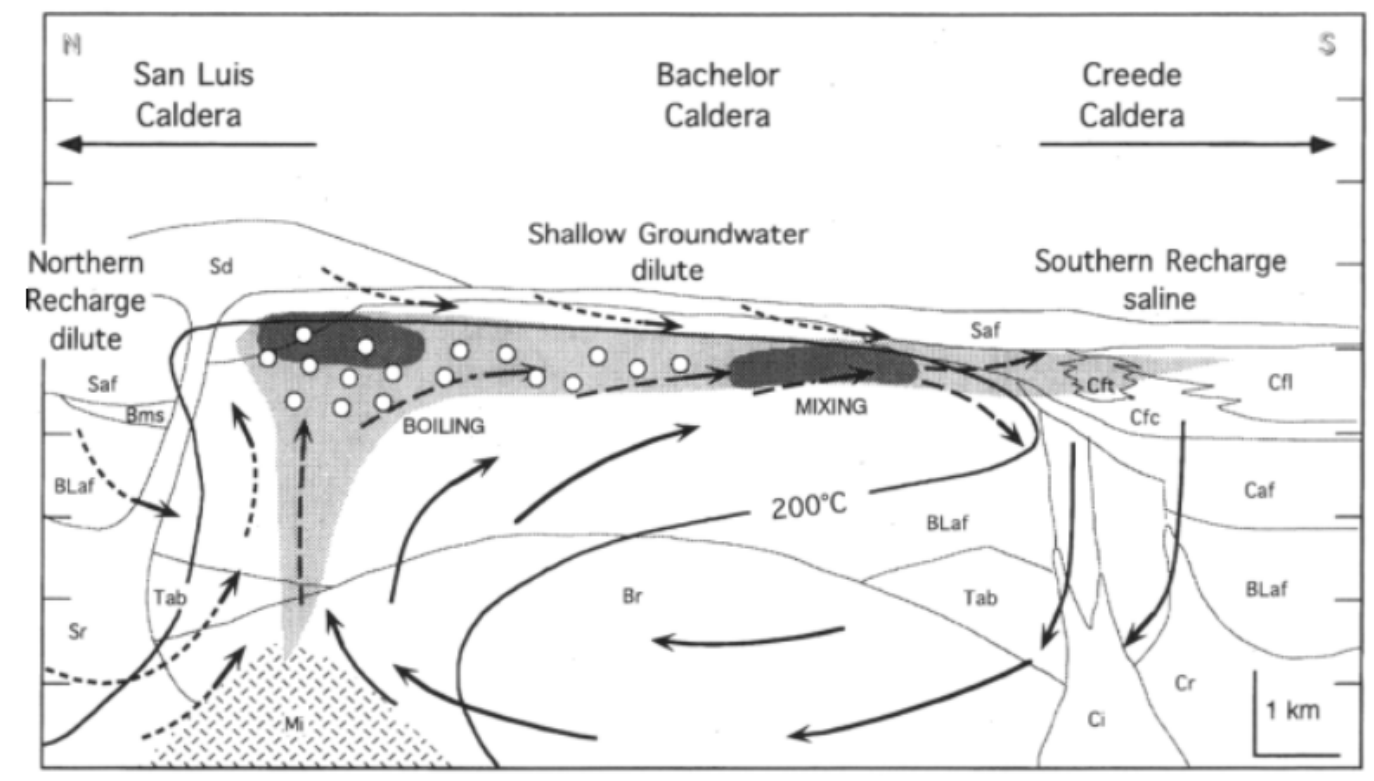

Figure 15. Model of convection, boiling, and mixing in the Creede District. (fig. 1 of Hayba, 1997, (OSociety of Economic Geologists).

Structural controls that focused fluid flow are described in both volcanogenic uranium deposits (George-Aniel and others, 1991; Rytuba, 1994; Castor and Henry, 2000; Chabiron and others, 2003) and epithermal metal systems (Sillitoe and Bonham, 1984; Simmons and others, 2005). Important features include caldera margin faults, linear fault zones, small intrusions (plugs), breccia pipes, and fracture zones in brittle welded tuff (figs. 17-19). The large U deposits at Pocos de Caldas and Streltsovskoye formed where intracaldera structures were the focus of multi-stage hydrothermal fluid flow. In layered volcanic sequences, aquitards created by beds or zones of clay-altered rock can be important by restricting flow and forcing fluids laterally outward from principal conduits (George-Aniel and others, 1991; Hayba, 1997). Fault zones or depressions at the top of the pre-volcanic "basement" focused flow and provided traps at Midnite, Austin, and Pitch mines (Nash and Lehrman, 1975; Plut, 1979; Nash, 1988). Caldera margins and moats filled with volcaniclastic and lacustrine deposits, as at Creede, Aurora and Date Creek, focus flow, create traps, and serve as loci for fluid mixing.

Syn-volcanic lakes that accumulate air-fall ash deposits and volcaniclastic sediments are a special hydrothermal environment, as shown by some precious-metals deposits (Vikre, 1987; Ebert and Rye, 1997; Wallace, 2003). Such lakes are the setting for volcanogenic uranium deposits at Date Creek (Sherborne and others, 1979), the Aurora deposit in the ring-fault zone at McDermitt (Roper and Wallace, 1981), and 
widespread uranium occurrences at Virgin Valley (Castor and Henry, 2000). For both precious-metal and uranium systems, the evidence indicates mixing of sediment pore water with upwelling geothermal waters carrying silica, possibly uranium, and, in places, fluorine and trace metals. The scale and vectors of flow are chiefly controlled by fault or fracture patterns and the location and size of heat sources (intrusions or sub-volcanic magma chambers).

Paleoflow models for ore deposits, or groundwater in general, are scarce for distal outflow volcanics. Extensive research at the Nevada Test site (for potential storage of nuclear waste) provides some helpful guides, but predictive models are not available. As a generalization, ash tuffs are probably aquitards, but welded tuffs can be aquifers where joints are developed in these brittle rocks (Winograd, 1971). The hydraulic conductivity of jointed and fractured welded tuffs is confirmed by numerous quantitative studies for the Nevada test site that include laboratory and in situ (well) tests (Smith and Sharp, 2006). Thus, long-distance meteoric water flow (tens of $\mathrm{km}$ ?) is likely within ash flow sheets in the proper basin or structural domain. This would facilitate the release and transport of uranium from source rocks, possibly into pre-volcanic traps as at the Pitch Mine, or within the volcanic sequence of tuffs and volcaniclastic rocks.

Convection is known to have important chemical consequences in epithermal ore and geothermal systems (Cathles, 1977; Henley and Ellis, 1983; Hayba, 1997) and needs to be considered in volcanogenic uranium deposit models. Examples are shown in figures 15,16 , and 17. Convection in a caldera setting, above a shallow intrusive body, was modeled for Pocas de Caldas as a $10 \times 10 \times 10 \mathrm{~km}$ system with boiling near the surface (Cathles and Shea, 1992). Convection driven by shallow magma chambers is one factor in the evolution of oxidizing brines in continental rifts, well known from the Salton Sea and other sites (McKibben and Hardie, 1997), and could be a model of ore-forming processes in some volcanic U settings. For volcanogenic uranium systems, as in epithermal metal systems, the key is a sub-volcanic magma chamber of sufficient size, proper depth, and heat content to drive convection, boiling, or mixing. Convection could be especially important for uranium systems, allowing recirculated meteoric water to repeatedly leach uranium from source rocks, yielding larger concentrations than a singlepass flow system. Gravity-driven convective flow (Garven and Raffensperger, 1997; Ebert and Rye, 1997) produces similar results. 


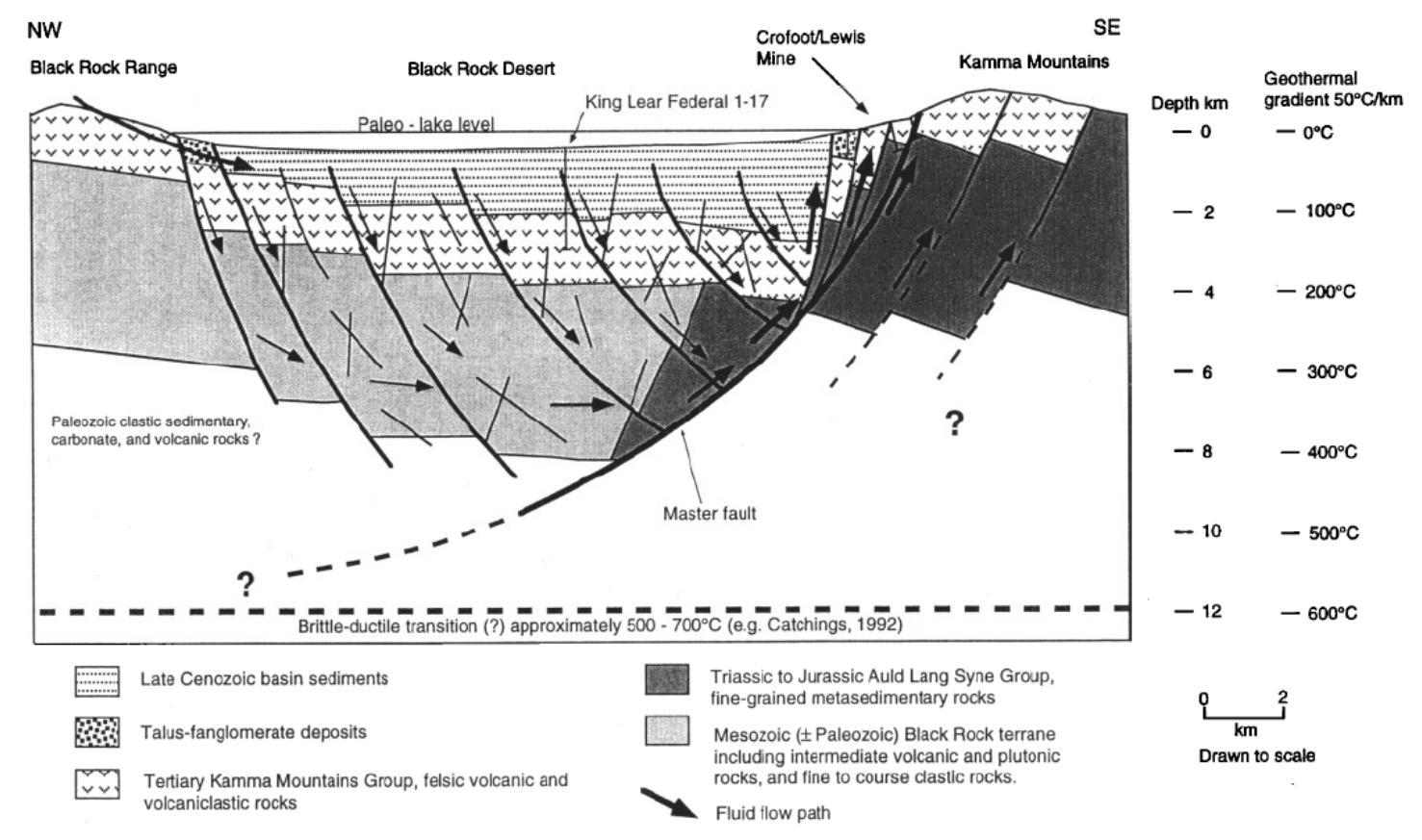

Figure 16. Model of deep meteoric flow and convection in a northern Nevada basin, driven by gravity and the elevated heat flow of the area. An igneous heat source is not shown but could be present. (fig. 14 of Ebert and Rye, 1997; (C) Society of Economic Geologists).

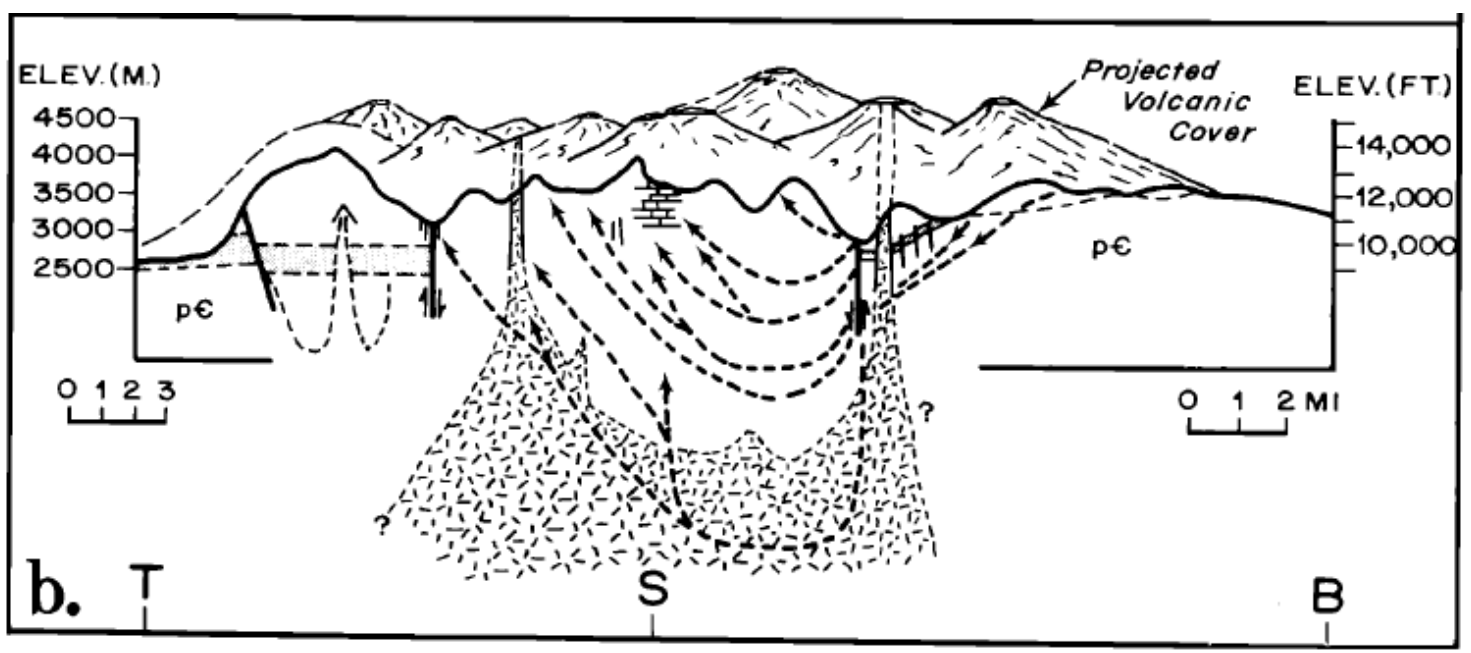

Figure 17. Deep circulation in the nested San Juan and Silverton calderas, Colorado, deduced from stable isotopic, fluid-inclusion, and other geochemical studies. Geologic and topographic reconstruction, with vertical exaggeration of 2.6. Dashed lines indicate suggested groundwater flow and convective fluid flow during mineralization. Abbreviations: T, Telluride; S, Sunnyside, B, Beartown. (fig. 22 of Casadevall and Ohmoto, 1977; CSociety of Economic Geologists). 


\section{Geochemical Signatures}

The trace element signature of most volcanogenic deposits is subtle compared to metal deposits. Trace elements associated with uranium-rich zones commonly resemble the suite that is well-known in epithermal systems (Castor and Henry, 2000): As, Bi, Sb, $\mathrm{Mo}, \mathrm{Se}, \mathrm{Hg}$, and W. Lithium and rare earth elements (REE) are enriched in some systems, as at Spor Mountain and McDermitt. Some deposits have strong Hg enrichment and some are spatially associated with $\mathrm{Hg}$ deposits, as at McDermitt, but this is not generally the case. Some deposits are rich in F, and these are enriched in Be, Mo, and Th, as at Spor Mountain. At a few deposits, the ore is enriched in $\mathrm{Zr}$; in some deposits the $\mathrm{Zr}$ enrichment is high enough to create refractory phases (Castor and Henry, 2000).

Concentrations of trace elements although enriched relative to unaltered rocks, tend to be modest (less than $50 \mathrm{ppm}$ ), lower than in most epithermal base-metal ores. ${ }^{6}$

Alteration-mineral assemblages associated with ore deposits provide information on the character of ore-transporting fluids and are useful guides to ore. For volcanogenic uranium deposits, diverse alteration minerals occur with the deposits reviewed above. Silica, in the form of opal or micro-crystalline quartz, is seen at nearly all deposits. Some silica reflects very high concentrations attained during alteration of glassy volcanic rocks (Zielinski, 1981), whereas in other settings silica precipitated during cooling of hydrothermal fluids (Fournier, 1985; Castor and Henry, 2000). Intermediate-composition volcanic rocks tend to be altered to montmorillonite and chlorite. Many altered rhyolites contain K-feldspar, sometimes in the form of adularia. At Pena Blanca, Mexico and Lakeview, Oregon, K-feldspar is a vapor-phase alteration product that pre-dates uranium ore deposition. Iron sulfide as pyrite and marcasite is common in volcanogenic uranium deposits. The amount of iron sulfide may be related to host rock composition: in rhyolite the amount of iron sulfide is relatively low (reflecting the low iron content of the rocks), but in intermediate-mafic rocks, as at Aurora, iron sulfides are abundant (Roper and Wallace, 1981). Work is needed to determine if Fe may be added by hydrothermal fluids and if total Fe content changes during supergene modification. Alteration near volcanogenic uranium deposits may be too localized and subtle to be detected in regional-scale remote sensing studies (discussed below).

6 Throughout this review I make numerous references to epithermal base- and preciousmetal systems, so this raises the good question: how do the uranium and epithermal systems differ? This is not easy to answer. Although the general geologic features and settings are very similar, there is little or no gradation between the two in terms of ore compositions. For example, there are no significant volcanogenic U deposits with byproduct $\mathrm{Ag}$ or $\mathrm{Au}$, and vice versa. Two differences in the metal transport process may account for the lack of gradation. 1) Volcanogenic uranium deposits generally form from highly oxidized fluids to transport uranium; transport conditions are more oxidizing than in metal systems. 2). Some epithermal ore-forming fluids contain both metals and reduced sulfur (for example, HS-), in the form of strong bisulfide-metal complexes (Seward and Barnes, 1997), but this is not possible in uranium systems because $U$ has very low solubility in the presence of sulfide ion. The depositional regimes and processes of these ore-forming systems also are very different. 
Acid-sulfate alteration is associated with a specific style of epithermal ore mineralization (Heald and others, 1987), and is associated with uranium deposition in some volcanic systems (Bagby, 1986). Acid-sulfate alteration, with its characteristic bright colors and distinctive minerals like alunite and jarosite, would be a valuable guide to a volcanogenic uranium deposit - if the association is valid. In this survey of known deposits, no important deposit has acid-sulfate alteration, and the famous acid-sulfate alteration at Marysvale, Utah, is not of the same age or location as the uranium deposits there (Cunningham and others, 1998). In theory, the acidic and oxidized nature of fluids in acid-sulfate systems would be ideal for leaching and transporting uranium. If these systems do not in fact produce significant uranium deposits, the failure may be lack of a depositional mechanism. The oxidized fluids may overwhelm potential reductants, or the solutions may be excessively acidic. My conclusion is that hypogene acid-sulfate systems are not favorable for uranium deposition. Supergene (hexavalent) uranium mineralization might be associated with supergene acid-sulfate mineral deposits above the water table.

\section{Uranium Deposition: Focused Flow, Traps, and Reductants}

A uranium ore deposit is a rare feature of geology that is both locally enriched and large enough in tonnage to be valuable when mined. The challenge is to understand and predict: 1) settings favorable for uranium enrichment, and 2) settings favorable for the accumulation of large amounts of uranium. Processes operating at the site of deposition are largely responsible for the economic viability of the deposit, although deposition obviously cannot occur without a source and transport. For significant deposits, focused flow, a trap, and reduction are required. An interface or zone of fluid mixing typically is required because it is difficult or impossible to transport sufficient $\mathrm{U}^{+6}$ with a reductant in the same solution. 


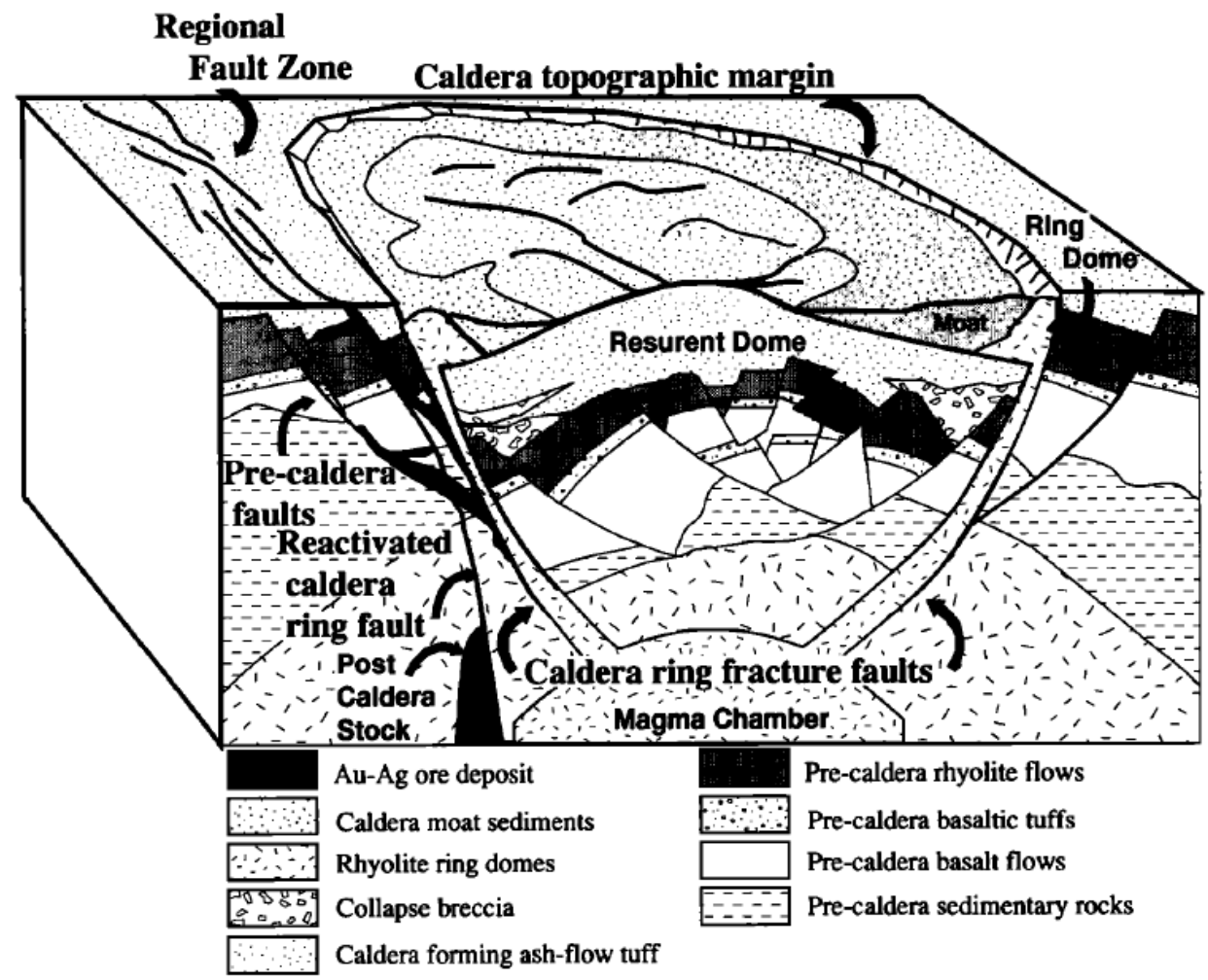

Figure 18. Caldera structures and localization of ore deposits in a resurgent caldera. (fig. 6 of Rytuba, 1994; @Society of Economic Geologists).

Uranium deposits form in "traps" or sites where fluid flow is focused and chemical processes are active to cause deposition. Depositional traps can be either physical (the intersection of a fault and a brittle rock unit, a breccia pipe, an aquitard, an anticline, or an intrusive contact) or chemical (a limestone bed, a pod of sulfide minerals, an inflow of sulfide-bearing fluid, or a lens of carbonaceous matter). Structural controls in a caldera system are best known (fig. 18) and easiest to predict from geologic maps. The best traps combine both physical and chemical properties to create high-grade ore zones. The scale of traps is variable from local features such as a small volcanic plug to beds or structures that are evident at quadrangle scale $(1: 24,000)$; they probably are not evident on state-scale maps $(1: 500,000)$. For uranium deposition in traps, a crucial process is reduction. Without reduction, $\mathrm{U}^{+6}$ will move through the trap; an exception is in supergene traps where yellow uranium minerals can precipitate (but these generally are not important deposits). 
Mixing of fluids has been found to cause ore deposition in many types of metal deposits, by fluids ranging from sea water to meteoric and magmatic (Ohmoto and others, 1983; Plumlee and others, 1994; Haynes and others, 1995; Hayba, 1997). Fluid-inclusion and stable isotopic data are most diagnostic of the sources and mixing process. Pioneering research on some uranium deposits shows that mixing processes are important for some sandstone-type ores (Goldhaber and others, 1990) and unconformity-type U ores (Kotzer and Kyser, 1995; Donatienne and others, 2005) (fig. 19). Mixing of diverse fluid types was proposed for the Aurora deposit (Roper and Wallace, 1981), along the caldera-margin fault zone. The crucial interface of two compositionally different solutions was demonstrated earlier by Granger (in Nash and others, 1981) and by Reynolds and Goldhaber (1983). In these mixing zones, uranium $\left(\mathrm{U}^{+6}\right)$ arrives in an oxidized fluid, encounters a solution of different composition or $\mathrm{pH}$ that triggers a reaction or reduction that causes uranium and gangue mineral precipitation. In volcanic settings, a likely situation would be an oxidizing, alkaline solution in which $\mathrm{U}^{+6}$ is stable as a bicarbonate complex mixing with a reducing, acidic solution in which marcasite can form (see below).

Boiling produces major chemical changes (Drummond and Ohmoto, 1985; Reed and Spycher, 1985), including release of volatiles such as $\mathrm{CO}_{2}$ that would destabilize carbonate- or other uranium complexes. Boiling also causes rapid cooling (Cathles, 1977; Cunningham and others, 1998) and mineral precipitation. Effervescence of $\mathrm{CO}_{2}$ is similar to boiling and was described as the key to U deposition at the Schwartzwalder uranium deposit (Wallace and Whelan, 1986). Boiling causes oxidation in some situations (Reed and Spycher, 1985); while this may facilitate gold deposition, oxidation is counterproductive for uranium deposition. Definitive fluid-inclusion studies have not been undertaken at most volcanogenic $U$ deposits, probably becuase transparent gangue minerals are generally fine grained and not amenable to fluid-inclusion studies. 


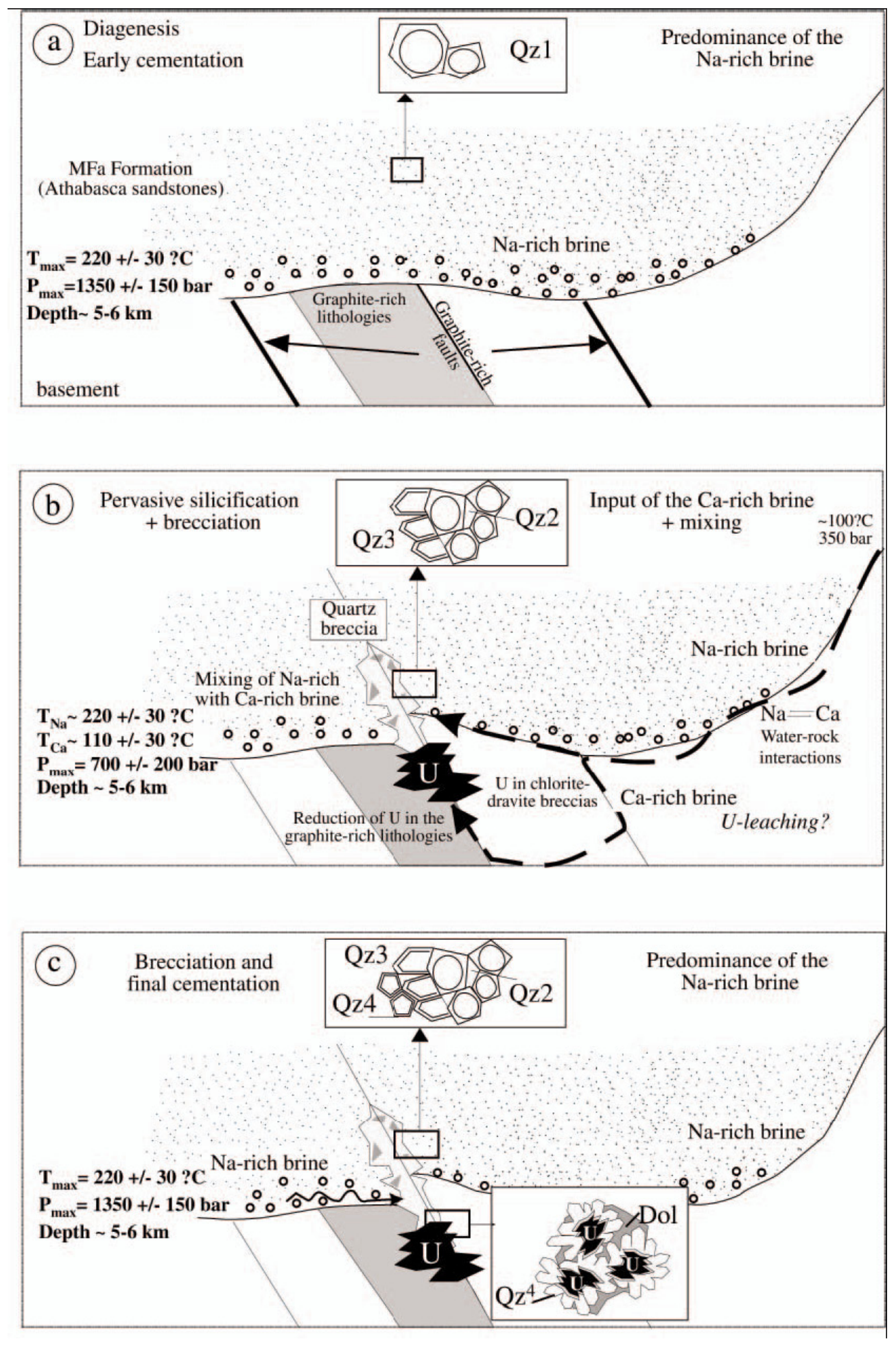

Figure 19. Three stages in the mixing of stratified $\mathrm{Na}$ - and Ca-rich brines at an unconformity-type $U$ deposit, Athabasca Basin, Canada. Uranium was carried by the Ca-brine and deposited upon mixing with the cooler Na-brine. (fig. 10 of Donatienne and others, 2005; @Society of Economic Geologists). 
Reduction in volcanogenic uranium deposits generally is controlled by sulfur chemistry; hydrogen sulfide, bisulfide ion, and several metastable sulfur-oxyanions are kinetically effective reductants for $\mathrm{U}^{+6}$ (Granger in Nash and others, 1981; Reynolds and Goldhaber, 1983). Carbon in various forms (logs, coal) and methane are only locally effective. Only a few reports on volcanogenic uranium deposits include mineralogical and chemical descriptions as a basis for a reduction mechanism. Descriptions of the Aurora sulfide zones (Roper and Wallace, 1981) are a good start, and some information is provided on the Margaritas (Pena Blanca) deposit sulfides that are overprinted by intense oxidation (George-Aniel and others, 1991). The reduction mechanism proposed for Marysvale (Cunningham and others, 1998) may be helpful for some similar environments, but processes related to boiling may not apply to most other settings. Some of the best concepts come from some elegant geochemical studies of sandstone-type uranium deposits (Granger and Warren, 1969; Reynolds and Goldhaber, 1983; Goldhaber and others, 1990). Based on experiments on the stability of marcasite (hexagonal $\mathrm{FeS}_{2}$; Murowchick and Barnes, 1986; Schoonen and Barnes, 1991) and metastable sulfur species (Goldhaber, 1983), reduction of uranium by reaction with sulfur should be viable to about $200^{\circ} \mathrm{C}$, which should suffice for many volcanogenic uranium environments. Formation of marcasite infers acidic conditions (below $\mathrm{pH} 4.5$ ), which may have implications for destabilizing U-complexes, such as bicarbonate-U.

At least five kinds of sulfur sources and reactions may be relevant for volcanogenic uranium deposits. 1) Hydrogen sulfide of various forms in hydrothermal fluids, well studied in epithermal metal deposits (Simmons and others, 2005) but neglected in volcanogenic uranium deposit studies. Possibly the best analog for reactions in volcanogenic $U$ deposits is the Schwartzwalder vein $U$ deposit. Wallace and Whelan (1986) proposed effervescence of $\mathrm{CO}_{2}$, destabilization of bicarbonate- $\mathrm{U}$ complexes, and reduction at the sulfide-sulfate boundary. Reactions proposed by Cunningham and others (1998) for Marysvale U deposition may also be relevant, but the boiling conditions and F-U transport may not be generally applicable. 2) Gaseous or dissolved $\mathrm{H}_{2} \mathrm{~S}$ may rise along faults from pre-volcanic, petroliferous sources, by analogy to some South Texas deposits in sandstone (Goldhaber and others, 1978). In that system, pre-ore pyrite was essential for ore-stage sulfide-U reactions. Hydrogen sulfide in oil field methane (sour gas) is an appealing reductant, but we should question how commonly petroleum reservoirs underlie volcanic systems. 3) Biogenic reduction of sulfate has been shown to be effective in many sediment-hosted $U$ deposits (Reynolds and Goldhaber, 1983; Nash and others, 1981; Loveley and Phillips, 1992). The limiting parameter possibly is the amount of carbon in volcanic systems to feed microbes. This mechanism likely operates in carbonaceous lacustrine sediments of the Date Creek type (Otton, 1985), or in interbedded carbonaceous shales and volcaniclastic sediments, but probably is not applicable to pure volcanic systems. 4) Partial oxidation of pre-existing sulfides can form metastable sulfur oxyanions that are powerful reductants of uranium (Granger and Warren, 1969; Reynolds and Goldhaber, 1983). Marcasite commonly forms in the partial oxidation process and has been found in many deposits when studied carefully by ore microscopy (Reynolds and Goldhaber, 1983), as is also the case with epithermal gold deposits (Nash and Trudel, 1996). The partial oxidation mechanism probably operated on 
pre-ore sulfides in the Aurora deposit, and has been proposed for the Midnite and Pitch deposits (Ludwig and others, 1981; Nash, 1988). 5) Metals (and perhaps uranium) can be reduced by ferrous iron in silicates and oxides. Reduction by ferrous iron has been proposed for volcanogenic massive sulfide deposits associated with submarine basalts and is supported by experiments in the range of 200 to $500^{\circ} \mathrm{C}$ (Mottl and others, 1979). Computer modeling of unconformity-type deposits has shown that $\mathrm{Fe}^{+2}$-silicate minerals such as garnet, biotite, and chlorite can be reductants for U (Komninou and Sverjensky, 1996; Alexandre and others, 2005). This mechanism is not generally applicable because most volcanogenic deposits are not in mafic rocks.

Reduction processes related to underlying oil and gas fields is a novel and speculative proposal for volcanogenic uranium deposits. The details of several reduction mechanisms have been established for South Texas uranium deposits above older petroleum reservoirs (Goldhaber and others, 1978), but these concepts have not been applied to volcanic systems. It is of interest to point out that in Nevada oil reservoirs include volcanic rocks and volcanic megabreccia; the source of the oil is both Mississippian marine shales and Tertiary nonmarine lacustrine deposits (French, 1983). Also, some of the oil fields in Nevada and other western states contain heavy oil and bitumen (Meyer and others, 2007). The microbial activity and basin-scale meteoric water flow that cause the degradation of light oil may possibly interact beneficially to produce uranium ore-forming processes. ${ }^{7}$ Coupled biodegraded hydrocarbons and bacterial reduction of sulfate and uranium caused precipitation of coffinite in a sandstone-type deposit, northwest China (Cai and others, 2007).

\section{Post Ore: Preservation, Enrichment, or Destruction}

Primary black (reduced) uranium mineralization is enriched by supergene processes in many volcanogenic uranium deposits, as described well for Pocos de Caldas (Waber and others, 1992) and Pena Blanca (George-Aniel and others, 1991). These changes are easily understood, and the processes are similar to those in supergeneenriched copper deposits. For most volcanogenic uranium settings, the addition of the supergene process will not change the assessment very much. However, variation in

7 The biodegradation that produces heavy oil is a topic of high interest because the heavy oil deposits of the world are huge and comprise a major fraction of total petroleum resources (Meyer and others, 2007). Some of the heavy oil fields have similarities to the Green River Formation, which contains low-grade uranium deposits that are part of the spectrum of lacustrine uranium deposits (Otton, 1985). Huge flows of meteoric water are required to nourish microbes, whose activity is limited to the range 50 to $176^{\circ} \mathrm{C}$, and the process requires tens of millions of years (Larter and others, 2003). Speculatively, this is a hydrologic situation that could aid the formation of sediment- or volcanic-hosted uranium deposits. Uranium assessment teams should look for possible process links between heavy oil systems and uranium systems. Other than some new concepts about basin flow and geochemical processes (for example, Larter and others, 2003), there is only one published report that pertains to uranium deposit genesis (Cai and others, 2007). 
down-dip flow induced by tectonic tilting could significantly change the deposits by destruction or redistribution.

Destruction of uranium deposits is not discussed in many uranium models. Tectonic stability is assumed in many models, and is evident in the preservation of many districts, including some dating to the Proterozoic in Canada and Australia. Only brief descriptions are given for structural changes that destroy deposits. For sandstone-type deposits, Finch and Davis (1985) note that deposits are "preserved because of only slight increases in dip." They note that initial dips are a few degrees, and the dips of some deposits increase to about five degrees during basin compaction with no adverse effect. Adams and Cramer (1985) provide helpful comments: very flat dips do not support significant groundwater flow, dips of 1 to 3 degrees provide optimum flow, and "steep dips may indicate flushing of aquifers and destruction of deposits."

There is some evidence that tectonism can redistribute primary ore. The example of Lodeve, discussed earlier, shows that the uranium in carbonaceous mudstones can be mobilized by oxidizing meteoric groundwaters and redeposited into high-grade deposits. In the Grants District of New Mexico, post-ore uplift created faults and tilted sandstone strata, to destroy carbonaceous-U ore (tabular type) and move it into new structures (stack ore; Granger and others, 1961). Elsewhere in New Mexico, carbonaceous ore in the Jackpile deposit was attacked and partially destroyed by oxidizing groundwater, but no redistributed ore could be found (Adams and others, 1978). Beneficial results from tectonism rely on fluid mixing in reduced zones produced by petroleum (Comte and others, 1986) or hydrogen sulfide to create conditions similar to roll-type deposits (Granger and others, 1961; and others).

\section{A Geologic Framework for Assessment}

Geologic descriptions and genetic processes discussed above show that there is considerable diversity among the known volcanogenic deposits, but also many common themes. However, many defining characteristics of volcanogenic uranium deposits require detailed laboratory analyses and geologic information in three dimensions from mine exposures or drill holes. The paucity of data for frontier areas and undiscovered deposits has been acknowledged for many decades of resource assessment for metals and uranium by the U.S. Geological Survey. Because such data are not available for large tracts requiring assessment, the framework outlined below for regional scale resource assessment $(1: 500,000)$ uses spatial databases that are known a priori to be much less complete than made during deposit studies. Available databases and their limitations will be discussed in a later section.

A geologic framework is proposed to cover the spectrum of possibilities for uranium in volcanic rock, from proximal to distal (fig. 20). The framework is structure and stratigraphy that should be evident at regional $(1: 500,000)$ scale and should focus attention on: a) caldera-related or proximal zones; and b) non-caldera or distal zones. Topical studies or detailed mapping may be available to characterize other features typical of calderas (such as megabreccia deposits, marginal intrusions, and resurgence), to help make the proximal setting more specific. Evaluation of the distal zone should 
consider the many styles of faulting, types of volcanic rocks (lavas, tuffs, and volcaniclastics), lacustrine volcaniclastics, and dikes or plugs. Pre-volcanic structures that could host uranium deposits (of the Pitch or Midnite type) should also be considered. Spatial databases, or maps, of geochemical and geophysical information need to be superimposed on the structural framework, using GIS (geographic information system) techniques, to find areas within tracts that are most favorable for ore deposition.

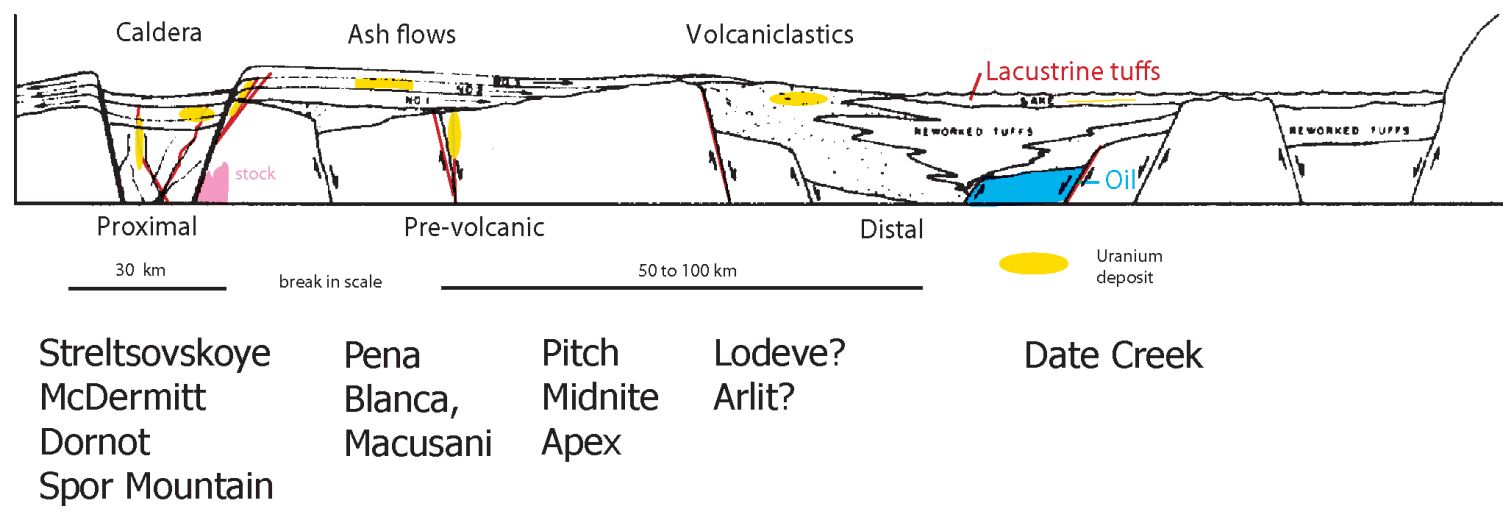

Figure 20. Schematic cross section of an idealized volcanic system showing postulated ore sites. Note that the horizontal scale is generalized, and the vertical and horizontal scales are not the same. Uranium-mineralized zones or deposits are exaggerated in size. Examples are shown, below their approximate geologic settings. (Base for section is from Sherborne and others, 1979).

The structural and lithologic framework for volcanogenic uranium deposit assessment needs to be continuously variable in four dimensions, from deposit-scale to crustal-scale features, through time. Time segments or slices, as used by Berger and Bonham (1990), are one means of connecting near-surface rocks and processes to deeper source regions that change with tectonic events. Ideally, the assessment team would use time slices of volcanic events, including facies and structures, proximal to distal.

Within this structural framework there are geochemical and other parameters related to ore-forming processes. Spatial data for these parameters, as provided in analyses of rock and stream sediment analyses, or remote sensing data, are required in an assessment. There are at least 24 criteria that can be used to evaluate the presence of undiscovered volcanogenic uranium deposits; each is spatial and amenable to map-based or GIS analysis.

This three-dimensional framework would be called a "model" by many. I prefer to avoid that term because it is used too often and vaguely, and generally is used for mineralogical and geochemical aspects of an ore deposit. This assessment framework, for regional-scale assessment, focuses on rocks rather than ores, which would be mere dots at 1:100,000 or 1:500,000 scales. The discussion below will shift to a more 
descriptive style because that is required for regional assessment. In places there will be references to earlier sections on processes and ore genesis where this substantiates the relevance of a parameter.

\section{Assessment for Volcanogenic Uranium Deposits}

\section{Introduction to Assessment Methods}

Assessment of mineral resources has utilized many different methods over the years (Harris, 1984; Singer, 2007) and the U.S. Geological Survey has been a leader in developing new methods (Singer, 1993; Ludington and Cox, 1996; Singer, 2007) that form the background for discussions here. Assessments, typically done by government agencies, are fundamentally the same as exploration programs by the private sector (up to the drilling stage), thus we can use concepts, tools, and databases generated by the mineral industry. Unlike exploration programs, assessments are not validated by drilling. However, it is evident from assessments made 40 or more years ago that these were minimum estimates because new deposit types, settings and genetic concepts were not included (T. Theodore, USGS, comments on Battle Mountain District, 1996). The impact of changing geological, mining, and metallurgical concepts for gold resources in northern Nevada are discussed by Wallace and others (2004). Likewise, changes in perspective are well shown by the emphasis on igneous uranium deposits, especially pegmatites and hydrothermal vein deposits in the 1950s, deposit types that now are insignificant contributors to United States and world resources.

Regional mineral-resource assessment of volcanogenic uranium deposits in the future may be done using some form of the three-step process (Singer, 1993; 2007): 1) delineate permissive tracts; 2) develop grade and tonnage model for the specific ore deposit type, and 3 ) estimate numbers of undiscovered deposits (that are thought to fit the grade-tonnage model). An additional step may be taken, simulation of resource endowments by Monte Carlo computer calculations, but is not a formal part of the recent USGS 3-step method.

\section{Assessment Step 1: Permissive Tract Delineation}

The first step in the assessment process, after databases are assembled and verified, is the delineation of geologic tracts that are permissive for volcanogenic uranium deposits. In the first step, it is important not to confuse "permissive" with "favorable." The delineation of permissive tracts eliminates terrane where occurrence is deemed by experts as highly unlikely. The elimination process keys on rock types that have a vanishingly small probability of hosting the model type under consideration. Thus, the probability of a deposit type occurring outside a permissive geologic tract is considered to be less than 0.00001 (Singer, 1993), or less than one in one hundred thousand. Other approaches are described by Singer (2007).

Permissive tract criteria should be fairly generic. Some examples: 1) the model calls for "impure carbonaceous limestone," but the permissive tract should also include thick-bedded, relatively clean platform carbonate rocks because they have small chance 
of hosting a deposit, and geologic maps may combine several kinds of carbonate rocks into one map unit; 2) the model highlights Cretaceous-Tertiary porphyry stocks, but the permissive tract should include porphyry stocks of all ages if there is not conclusive evidence for an age limitation for the ore-forming process (or the grade-tonnage model may have a specific age criterion); 3) epithermal vein deposits (Comstock type) are associated with Tertiary volcanic rocks, but the permissive tract must also cover structural permeability, thus the permissive tract is defined by both volcanic geology and a structural zone that is largely empirical because not all structures and ages are favorable (Ludington and Cox, 1996). The permissive tract for epithermal vein deposits of the western United States, shown on figure 1, is a good analog for the permissive tract for volcanogenic uranium deposits.

The permissive geologic tract for volcanogenic uranium deposits is quite simply defined as: a geologic terrane that includes volcanic and volcaniclastic rocks that are felsic to intermediate in composition $\left(\mathrm{SiO}_{2}>65 \mathrm{wt}\right.$ percent). The term "volcanic" includes flows, tuffs, and shallow intrusions. Assuming that a GIS will be employed, the spatial definition should include: 1) a buffer $10 \mathrm{~km}$ wider than exposed volcanic rocks to include possible eroded areas; 2) the tract should extend under younger cover rocks, including alluvium, to a depth of cover estimated to be less than $1 \mathrm{~km}$ using geological or geophysical criteria.

The composition is set broader than the ideal, to include volcanic rocks that might allow processes to operate in much the same way as those with $>72$ wt percent $\mathrm{SiO}_{2}$. In this first step of the assessment no consideration is given to finer details of magmatism, following the advice of Castor and Henry (2000) that uranium deposits may form from a broad spectrum of compositions. The age of rocks in a tract should not be restricted, because variants of any age can host deposits, including those that are metamorphosed. This broad definition of "volcanic" is designed to be inclusive at this stage, while eliminating rock types that offer no hope of hosting a volcanogenic uranium deposit. Ideally, the permissive tract should take into consideration zones that have been stripped of their volcanic rocks that would be relevant to Pitch- or Midnite-type deposits in prevolcanic structures. The tract delineation process should include areas with volcanic rocks covered by up to $1 \mathrm{~km}$ of post-volcanic rocks or alluvium (that is, expand the tract into alluvial basins up to $1 \mathrm{~km}$ deep).

\section{Assessment Step 2: Grade and Tonnage Model}

Uranium grades and tonnages of known deposits have been described earlier in this report and are discussed further in the appendix. The previous grade-tonnage model (Mosier, 1986) needs to be revised, especially to include new information for larger deposits discovered in Asia. This is well explained by Cuney and Kyser (2009, p. 21):

"The development of ore deposit models...is, in some cases limited by the restricted access to some deposits by the researchers. For example, all the deposits controlled by the former USSR were virtually inaccessible to western scientists. Prior to this, volcanic-related deposits were considered by most western researchers as minor resources. The realization by western geologists of 
significant $U$ resources in Transbaikalia, Mongolia, and Kazakhstan has led to reconsideration of deposit models related to volcanism and their resource potential."

Deposits and resource numbers are discussed in the appendix. The data for 32 deposits do not warrant detailed statistical analysis, but some descriptive statistics may be helpful. Average grade is 0.16 percent $\mathrm{U}_{3} \mathrm{O}_{8}$ and the median value is 0.14 percent $\mathrm{U}_{3} \mathrm{O}_{8}$, reflecting the larger number of lower-grade deposits in this tabulation. The average tonnage is $6,100 \mathrm{t} \mathrm{U}_{3} \mathrm{O}_{8}$ and the median is $350 \mathrm{t} \mathrm{U}_{3} \mathrm{O}_{8}$; the large difference between the median and average reflects the large number of very small deposits. Note that here and elsewhere in this report, tonnage refers to contained uranium not uranium ore; in most USGS-authored assessment reports tonnage refers to ore not metal.

The tonnages in recently developed deposits in Asia are well above the average and median for the 32 deposits. The trend in deposit size, when recent exploration results are included, projects a median uranium tonnage that is substantially higher than suggested using pre-1985 data summarized by Mosier (1986). The trend suggests a typical deposit contains roughly 5,000 $\mathrm{t} \mathrm{U}_{3} \mathrm{O}_{8}$, and deposits in the 5,000-20,000 $\mathrm{t} \mathrm{U}_{3} \mathrm{O}_{8}$ range are likely. The average grade of undiscovered deposits may be about 0.15 percent $\mathrm{U}_{3} \mathrm{O}_{8}$, but this estimate is uncertain because it is dependent on mining methods. If publicly available information (journal publications or trade reports available on the Web) are representative, there have been few recent discoveries in the U.S. This suggests that research, exploration, and drilling in frontier areas for new volcanogenic deposits has been lagging behind that in other types of $U$ environments, even in the last few years (2004-2008) of higher uranium prices.

Further discussions are needed between economic geologists and commodity experts to make revised models that are faithful to the descriptive geologic model. Resource numbers should carry spatial dimensions, such as the distance between deposits or the area serviced by a mine, taking into account that a mine may operate on more than one deposit. Much uranium production data have been for districts, which hampers geological analysis. Rules should be set for distance between a known deposit, and an extension of the deposit or a new undiscovered deposit; that distance is specified by some as more than $1 \mathrm{~km}$.

\section{Assessment Step 3A: Estimates of Number of Undiscovered Deposits}

In a quantitative mineral resource assessment, the third part is estimation of the number of undiscovered deposits within a certain permissive tract. Some assessment teams simultaneously undertake a favorability estimate (step 3B, below) Although these steps are subjective and not verifiable, reliability of estimates can be greatly improved using spatial databases and GIS in combination with deposit models. Each member of the assessment team should consider all available data for the permissive tract in the context of the model for the mineral deposit, based on experience. An essential aspect of this step is a working understanding of both the geologic and the grade-tonnage models. Useful suggestions are provided by Barton and others (1995) and Singer (2007). In my 
experience, the greatest problem is limited geologic experience in and around known deposits. Hands-on experience is the best teacher and provides respect for the uniqueness of a major ore deposit and the subtle differences relative to nearby showings and prospects.

My experience on roughly ten quantitative, three-part USGS assessments was mostly positive. To me, step 3a, estimation of numbers of deposits, is most subjective. Each geoscientist on the team should consider all available data for the permissive tract in the context of the model for the mineral deposit, and his or her experience. From what I have witnessed, experience on the ground in mines of the model type is important. Understanding the area geology and its nuances also helps. Understanding area geography (soils, weathering character, relief, vegetation cover, etc) also is important in the visualization that is required.

The actual estimate of deposits is as much art as science. It is a fact of U.S. Geological Survey assessments, and others of similar nature by mineral or petroleum geoscientists, that the outlook of the scientist is a major factor: there are optimists and pessimists. The estimates are made in a simple voting process, using paper ballots. Some are comfortable with bad data or zero data for various criteria, but others become frusturated when only part of the model is described. Some are inclined to vote for many small deposits (low tonnage on the grade-tonnage curve), whereas others vote for the possibility of a large deposit. Some geologists, or estimation teams, leave the computation of endowment to the monte carlo stimulation (step 3), but some relevant estimates, in my opinion, demand limits on the resource estimate, based on experience and a sense of what is likely. Most teams use secret ballots to minimize peer pressure. The team should set rules for tabulating results; many agree to discard the highest and lowest votes.

The spirit of the discussions and voting is important. Each voter should be independent, but not rebellious or dogmatic. Discussions dominated by an opinionated specialist (geochemist? geophysicist?) can create hard feelings and a wide spread in estimates. Discussions often turn toward an expert on the deposit type, but with secret ballots the group does not necessarily adopt the expert's estimate.

Estimates of the number of undiscovered deposits also are influenced by the quantity and quality of available information. There are several problems here. 1) Estimators tend to be comfortable predicting undiscovered deposits near known deposits, in part because there is generally more diagnostic data available. Also, optimism seems to be boosted by visible headframes and haul trucks. 2) Conversely, estimators tend to lack courage in making predictions in parts of permissive areas that have limited data. Lack of data should not be allowed to equate to less favorable, although it is instinctive to make this error. One of the best ways to minimize this effect is to have a panel moderator challenge the panel while not imparting bias. 3) Availability of data could provide a measure of confidence (in the statistical sense) in an estimate. At present there seem to be no methods for this measure. The estimate of an undiscovered deposit can be a wild guess, based on poor judgment or bad data, or supported by relevant science. If the 
estimation process is done carefully and well documented, there is an indication of "uncertainty" (Singer, 2007) in the spread in number estimates.

\section{Assessment Step 3B: Favorability Levels and Maps}

For land-use decisions, mineral exploration, or predicting environmental impacts, maps showing locations where a deposit is most likely to be discovered are useful, but these maps do not constitute a mineral assessment. Many users want to know which areas are most likely to contain deposits and how much metal is likely to be present at a site. These important questions are not addressed in regional mineral resource assessment of the three-part type (Singer, 1993). Locations of sites or areas thought to contain undiscovered deposits are done by various methods of favorability analysis, some of which have been done by the USGS.

Favorability can be estimated, or ranked, by how closely the available information for an area meets the deposit model. Levels of favorability and numerical methods are discussed elsewhere (Adams and Cramer, 1986; Peters and others, 1996). Note that there is a major handicap for a regional-scale assessment: descriptive data that can be shown to be diagnostic of a well-studied deposit often are not available for frontier areas. This is especially true for geochemical methods that require careful sampling of rocks and ores (stable isotopes, alteration mineralogy and paragenesis, and fluid inclusions) or geophysical methods that require close spaced and specialized measurements (low elevation or ground electromagnetic surveys, or wavelength-specific remote sensing such as AVIRIS). The criteria listed below do not rely on these special methods. The assessment criteria could be much more specific and diagnostic if better data were available. The NURE (National Uranium Resource Evaluation) program for regional assessment (1975-1982) took steps in this direction, and even with the large budget it made relatively modest advances for the assessment process.

It is likely that the amount of information available will influence assessment scores. The psychometric factors and uncertainties relating to estimator knowledge and data availability are generally the same as for estimating numbers of deposits, previously discussed. The dilemma of estimating in areas having limited data is especially grave: there is a strong tendency to minimize favorability where there is little diagnostic data. Comparing or ranking favorable areas can be difficult if data coverage differs; for this situation a method is needed to normalize the scores for kinds and quality of available data. One scoring method would be to make a ratio of positive points to possible points. A more complex system is described by McCammon (1992) with as many as 1,000 points for a modeled polygon. Other numerical models are discussed by Adams and Cramer (1986). This assessment technology is complex and needs much new effort. A simpler approach would be to generate maps that show the amount of information within permissive tracts; this might show shades of gray for the 24 criteria (Table 1) and supporting attributes.

The ranking method suggested here involves many criteria that are deemed important in the formation (or destruction) of a volcanogenic uranium deposit. The criteria listed are not required for a deposit to form or exist, but are considered favorable 
based on empirical or theoretical relationships discussed in earlier sections. Points are given to the criteria, such as +0.5 or +2 , which reflect the importance given to them by the author. In this simple system the criteria are additive; there are no criteria the absence of which produces a score of zero. To rank favorability of polygons within permissive tracts, simply sum the results for the criteria below. Three ranks of favorability are suggested: A. Low favorability (permissive), 1 to 5 points; B. Medium favorability (favorable), 5.5 to 10 points; C. High favorability (prospective), , $>10$ points. Clearly, the amount of information available will influence the scores. In the criteria below a "+" sign indicates favorable, a "-"sign indicates unfavorable.

\section{Quantitative Assessment Criteria}

The criteria listed below are suggested for estimating favorability or the number of undiscovered deposits in an assessment tract. The databases relevant to these criteria must be spatial (include data for location in latitude and longitude), but some of the attributes may need to be processed in a GIS to be useful. Some of the geologic attributes are stratigraphic units and for them the geologic map polygon for that unit should be used (table 1). Chemical analyses of a rock unit should be related to a stratigraphic unit (polygon). In an assessment analysis, faults generally are highlighted through the use of a "buffer" to expand the influence to a wider zone; here I suggest a buffer $5 \mathrm{~km}$ wide on both sides of a structure. Anomalous geochemical samples are point data, but should be represented by a buffer of 3 or $5 \mathrm{~km}$; I suggest the $5 \mathrm{~km}$ buffer for stream sediment sites because they in fact represent rocks in an upstream basin. Evaporite sediments and oil fields reflect basins and should be represented by a polygon. Some of the polygons can be generated automatically by a GIS, but some may require manual processing by an expert. The assessment process will at times essentially overlay the polygons using GIS tools. 
Table 2. Summary of assessment criteria for Volcanogenic Uranium Deposits.

$\begin{array}{llll}\text { Number } & \text { Criteria } & \text { Weight } & \text { GIS Treatment } \\ \text { G1 } & \text { Specialized rhyolite } & & \\ \text { G2 } & \text { Caldera structure } & +2 & \text { Stratigraphic polygon } \\ \text { G3 } & \text { Duration of thermal activity } & +2 & \text { Buffer line } 5 \mathrm{~km} \\ \text { G4 } & \text { Multiple intrusion, collapse } & +2 & \text { Buffer polygon } 10 \mathrm{~km} \\ \text { G5 } & \text { Extensional faults } & +1 & \text { Stratigraphic polygon } \\ \text { G6 } & \text { Lacustrine volcaniclastics } & +2 & \text { Buffer line } 5 \mathrm{~km} \\ \text { G7 } & \text { Fe-rich rocks } & +1 & \text { Stratigraphic polygon } \\ \text { G8 } & \text { Subjacent oil field } & \text { Stratigraphic polygon } \\ \text { G9 } & \text { Evaporite basin } & +0.5 & \text { Polygon } \\ \text { G10 } & \text { Wet paleoclimate } & +0.5 & \text { Polygon } \\ \text { G11 } & \text { Regional F enrichment } & +0.5 & \text { Polygon, generalized } \\ \text { G12 } & \text { Associated epithermal deposits } & +1 & \text { Polygon, generalized } \\ \text { G13 } & \text { Tectonic instability } & -2 & \text { Polygon of tract } \\ \text { Gx14 } & \text { SiO }>\text { 76 wt percent } & +1 & \text { Polygon, generalized } \\ \text { Gx15 } & \text { Anomalous rock trace metals } & +1 & \text { Buffer point } 5 \mathrm{~km} \\ \text { Gx16 } & \text { Anomalous stream sed chemistry } & +0.5 & \text { Buffer point } 3 \mathrm{~km} \\ \text { Gx17 } & \text { Silica alteration } & +1 & \text { Buffer point } 5 \mathrm{~km} \\ \text { Gp18 } & \text { Airborne radiometric anomaly } & +0.5 & \text { Buffer point } 3 \mathrm{~km} \\ \text { Gp19 } & \text { Remote sensing limonite } & +1 & \text { Buffer polygon } 3 \mathrm{~km} \\ \text { Gp20 } & \text { Remote sensing hematite } & +1 & \text { Buffer polygon } 3 \mathrm{~km} \\ \text { Gp21 } & \text { Airborne magnetic low } & +1 & \text { Buffer polygon } 3 \mathrm{~km} \\ \text { Gp22 } & \text { Geophysical model intrusion } & +1 & \text { Polygon } \\ \text { Mrd23 } & \text { Trend of U mines, prospects } & +2 & \text { Polygon } \\ \text { Mrd24 } & \text { Trend of Hg, Be, Mo prospects } & +0.5 & \text { Buffer polygon } 5 \mathrm{~km} \\ & & & \text { Buffer polygon } 5 \mathrm{~km}\end{array}$




\section{Geology}

Known or Inferred Presence of:

1. Specialized rhyolite (alkaline or topaz rhyolite by chemistry or modal analysis) $+\mathbf{2}$; high silica rhyolite $+\mathbf{1}$.

Comment: Discussed under magmatism; these rocks tend to be enriched in U, and many known deposits are associated with specialized rhyolites. Based on deposit descriptions and tonnage relations, specialized rhyolite is not sufficient to make a deposit, nor does it predict the size of the deposit.

2. Circular structure/caldera +2 .

Comment: Caldera structures have long been recognized as favorable for ore deposits in general, and for $U$ deposits this is well shown at McDermitt. There also is the possibility of a related shallow intrusion, and this possible heat source enhances possibilities for hydrothermal circulation. This criterion is given two points because several favorable attributes (empirical and theoretical) coincide with these structures.

3. Evidence for long thermal activity (2 to 10 Ma or more) +1

Comment: First proposed by Rytuba and others (1979), this criterion relates to liberation of $U$ from source rocks, most obviously in caldera settings, but also in distal settings. This criterion also relates to deep convective flow.

Geothermal calculations show that high heat flow can be caused by high concentrations of K-U-Th. This criterion is supported by empirical and conceptual relations.

4. Evidence for multiple stages of intrusion, venting, collapse, or resurgence +2 Comment: This is similar in concept to number 3, but supporting evidence may differ. Collapse or resurgence of calderas (Sillitoe and Bonham, 1984) should be considered here for their role in changing groundwater hydrology, which promotes better flow inside or outside the caldera. This may be the regional geologic evidence for the influx of oxidizing meteoric water that triggered U emplacement at Streltsovskoye and Pocos de Caldas, previously discussed. These stages can be tens of Ma after primary volcanism.

5. Extensional (normal) faults +1

Comment: Extensional tectonics are noted for many known deposits, inferred to be relevant to both magmatism and structural permeability.

6. Lacustrine volcaniclastic deposits +2

Comment: Distal deposits occur in lacustrine rocks in many places, and proximal deposits are associated with caldera moat-filling volcanics at McDermitt. This criterion expresses both a structural setting that is favorable for deposits, and a hydrologic setting that is favorable for circulation of hydrothermal fluids. See also number 8 .

7. Adjacent or interbedded Fe-rich beds (basalt or equivalent mafic rocks) +1 Comment: Iron-rich rocks are postulated to be effective reductants of U. Empirically, mafic flows control U at the Aurora prospect, McDermitt caldera. This is a problematic criterion because mafic rocks generally are not effective hosts, but the example of Aurora is impressive. 
8. Spatially associated oil and gas fields $+\mathbf{0 . 5}$

Comment: This is a novel and untested criterion taken from the South Texas sandstone-hosted deposits, which may not be relevant. In theory, and in some Nevada basins, oil and gas do circulate into volcanic flows and volcaniclastics. The concept is that the petroliferous fluids would promote sulfate-reducing processes.

9. Associated evaporite beds $\mathbf{+ 0 . 5}$

Comment: This is a novel and untested criterion based on a theoretical concept and spatial associations in many sandstone-type districts. Evaporite strata below some sandstone-type districts are shown to be the source of isotopically distinctive sulfur, and there is empirical evidence in the spatial association in some sandstone districts. Geochemical models postulate that the distinctively high oxidation state of some U systems can be related to sulfate-rich brines. Fluid inclusion data in volcanogenic uranium deposits are ambiguous regarding this criterion; documented very saline inclusions are thought to be related to boiling, but moderate salinity fluids (lacking daughter minerals) are not documented in volcanogenic uranium deposits.

10. Evidence for wet paleoclimate $+\mathbf{0 . 5}$

Comment: Wet paleoclimate is known to be a genetic factor in well-studied Nevada epithermal systems. The same concept should apply to systems in which $\mathrm{U}$ moves in meteoric groundwater. The wet paleoclimate recharges groundwater and also promotes diagenetic or hydrothermal alteration of volcanic rocks, which liberates $U$.

11. In area of known $F$ enrichment or deposits (F map) $+\mathbf{1}$

Comment: The spatial and geochemical association of $U$ deposits with $F$ is well established in districts such as Spor Mountain, and in topaz rhyolites that are F-rich. Fluorite is a common gangue mineral in volcanogenic uranium deposits. However, many volcanogenic uranium deposits are not enriched in $\mathrm{F}$, and $\mathrm{F}$ is not required for $\mathrm{U}$ transport in most situations.

12. Within favorable tract for epithermal precious metal deposits $+\mathbf{1}$ Comment: This criterion is redundant with criteria above, but is included because it adds assurance to the estimate. The geology of epithermal deposits closely resembles volcanogenic uranium deposits, in theory and in space, yet the deposits rarely coincide. For regional assessment they are in the same general parts of the crust, and that is positive information.

13. Tectonic instability: if dips or tilt $>10 \mathrm{deg}-2$ (subtract)

Comment: This criterion relates to preservation of uranium deposits. Post-ore tectonism, with changes to hydrology, can either enrich or destroy uranium deposits because uranium ore minerals are susceptible to dissolution in oxidizing recharge water. There are no absolute indicators of destruction, but it seems likely that highly tilted strata or blocks will be most subject to oxidation and associated destruction. The criteria for preservation of roll-front sandstone-type deposits is dips less than about 5 degrees (Adams and Cramer, 1985; Finch and Davis, 1985). 


\section{Geochemistry}

Known or Inferred Presence of:

14. $\mathrm{SiO}_{2}>76$ percent +1 (but not if criteria number 1 is met)

Comment: There is no magic number for the $\mathrm{SiO}_{2}-\mathrm{U}$ association, but magmas with more than 76 percent generally have highest $U$ content.

15. Anomalous trace elements $(M o, F, T h)$ in rock analyses +1

Comment: The association with these trace elements is seen in many deposits, but certainly not all. Because $U$ is mobile in many environments and may be depleted by weathering of sampled media, these elements may survive as pathfinder clues.

16. Anomalous $U, A s, B e, M o, S b, T h$, or $W$ in NURE stream sediments +0.5 Comment: These elements are frequently enriched in stream-sediment samples near deposits and are recommended by many geochemists to detect deposits or favorable source rocks. In my experience, the stream-sediment media was not effective for U programs, possibly because the magnitude of enrichment in alteration and ore is modest compared to base-metal deposits, and weathering depletes $U$. The concept is good but the efficacy is not.

17. Literature reports of pervasive silicification +1

Comment: Silicification, broadly defined, is associated with nearly all volcanogenic uranium deposits. I consider this a good criterion, but data for it are difficult to obtain. It cannot be determined remotely (except in very detailed and specialized surveys) and rarely is shown on detailed maps (1:24,000 scale). Also, it is important to discriminate it from other kinds of silicification, such as jasperoid in limestone. This generally would require experience in specific areas by someone on the assessment team.

\section{Geophysics}

Known or Inferred Presence of:

18. Airborne radiometric anomalies for $U$ or large $U: T h$ variation $+\mathbf{0 . 5}$ Comment: There are numerous publications and opinions on this topic, beyond the scope of this report. Some deposits have, in fact, been located by "aero rad", but those were chiefly in the early days of uranium exploration (pre-1970). Because $U$ is easily leached in the weathering zone, and aero rad senses only the upper few centimeters of the surface, there are good reasons for the lack of success. Also, many positive anomalies reflect areas of bold outcrop. In my experience, this method is not productive at regional scale, with broadly spaced flight lines. Computer enhancement and computations such as U:Th ratio and variations may be more productive.

19. Remote sensing anomaly for iron oxide (limonite) that could reflect weathered pyrite +1

Comment: There is abundant literature on the technology and geochemical applications. Because pyrite and marcasite are nearly always enriched in 
volcanogenic uranium deposits, the weathered expression of them would be of high value. Obviously, not all limonite is related to uranium. There are geochemical reasons for survival of limonite from primary sulfides but not uranium minerals or radioactivity.

20. Remote sensing spectral indications of hematite (hydrothermal) alteration)+1 Comment: Hydrothermal hematite accompanies some volcanogenic uranium deposits and is a diagnostic alteration product. Note that this crystalline form of iron oxide is not to be confused with weathering products such as limonite and goethite. Resolution of hematite spectra requires special equipment, and the data probably are not widely available at a regional scale.

21. Magnetic low that seems to reflect sulfidation of magnetite +1

Comment: Sulfidation of magnetite in volcanic rocks occurs in the vicinity of volcanogenic uranium deposits, and this alteration should be reflected by the loss of a magnetic signature. Destruction of magnetite, or demagnetization, is commonly observed at epithermal systems, producing magnetic lows, flat zones, or linear anomalies (Allis, 1990; Irvine and Smith, 1990; Klein and Bankey, 1992). Detailed, close-spaced flight lines are best.

22. Magnetic or gravity model that suggests concealed/blind intrusion below volcanic +1

Comment: Geophysical evidence for an unexposed intrusion below volcanic rocks, in either proximal or distal settings, would be supportive of conceptual convective circulation and related source and transport processes. The data and computational requirements for such a model are substantial, thus they may not be available in regional geophysical analyses and maps, but they might be computed if needed.

\section{Other Databases}

23. Adjacent to or aligned with known U prospects or mines $(M R D S)+2$ Comment: Mineral occurrence maps, such as from MRDS (Mineral Resources Data System of the USGS), can be very helpful in resource analysis by suggesting trends of deposits. The reliability of these databases is variable and some data fields are more complete than others. Prospects reported in MRDS may be useful as evidence for an undiscovered deposit. Also, prospects that are reported by industry in press releases would be considered "undiscovered" until there is sufficient drilling to define economic feasibility.

24. Adjacent to known $\mathrm{Hg}, \mathrm{Be}$, or Mo prospects or mines $+\mathbf{0 . 5}$

Comment: Zoning of ore deposits is a powerful exploration and assessment concept, but the relationship of epithermal metal deposits to volcanogenic uranium deposits, if any, is not established. In a few places, such as $\mathrm{McDermitt}$, there may be a spatial and genetic connection, and the Be-U association is very clear at Spor Mountain (but this is a rare type of deposit). 


\section{Assessment Databases}

\section{Geology}

The evaluation process should be based on the best available geologic maps. The process starts with state-scale geologic maps (presumably 1:500,000), but scales of 1:250,000, 1:100,000, and even larger should be used where available.

- Topical maps of volcanic rocks in which structures and units are highlighted or interpreted, such as volcanic units by age and composition (Luedke and Smith, 1984), or by tectonic setting and composition (Ludington and others, 1996) that summarizes known calderas.

- Lithology maps, derived from geologic maps, showing major rock types are very helpful; the prime rock for this assessment is "rhyolite", broadly defined.

- Structural maps are helpful, especially those showing calderas. Faults shown on regional maps typically are not those that control ore deposits, thus locations of smaller or branching structures are required, hence the need for larger-scale maps.

- Magmatic-tectonic compilations, or time-space slices, are important in pointing to favorable near-surface volcanic features and possibly important deeper crust and subduction zones and the implications of them for magma and uranium sources. New compilations should build on examples such as Berger and Bonham (1990) for epithermal deposits.

- GIS maps with supporting databases that allow queries. Because of the amount of information contained in a geologic map, it is important that the map units (polygons) be coded and accessible by query, as is standard practice in a GIS. A uranium assessment should build on earlier compilations and assessments. The inferior alternative is to do the searches by eye and to create a series of paper overlays.

\section{Geochemistry}

Types of geochemical databases that should be assembled in a GIS include:

- NURE stream-sediment chemistry, from the National Uranium Resource Evaluation program (1975 to about 1985), now revised and included as part of the U. S. Geological Survey National Geochemical Database (Hoffman and others, 1994; Smith, 1997). Despite differences in sampling and analysis protocols, the NURE stream-sediment database contains the best data available for most of the United States. The use of $U$ in stream-sediment samples as a guide to uranium deposits is constrained by several problems. Uranium may not persist in stream sediments downstream from a mineralized source. In addition, anomalously high values may arise from refractory heavy minerals such as monazite; uranium carried by heavy minerals generally is not a guide to uranium mineralization.

- U. S. Geological Survey and other sources of stream-sediment data. Samples collected and analyzed by the U. S. Geological Survey are described in the 
National Geochemical Database (Smith and Smith, 2005). This database includes several kinds of samples (different size fractions, and different density fractions such as panned concentrates). Uranium contents for various media should be considered independently as they represent distinctly different populations .

- Analyses of rocks (fresh and altered) for major and trace elements, stored in the National Geochemical Database (Smith and Smith, 2005; Granitto and others, 2005), are valuable for more than the results for $U$ and Th. Rock descriptions, major-oxide values, and normative calculations are just some of the information that can be used to identify rhyolites (or more specific rock types). A simple criterion such as $\mathrm{SiO} 2>74$ wt percent could be queried to find the geographic distribution of samples coded as volcanic or subvolcanic.

- MRDS database of mines and prospects contains information on principal mineral commodities, production, reserves and resources (where known), mineralogy, geologic setting, and geochemistry (see http://tin.er.usgs.gov/mrds/). Because they are tied to specific locations, data on mines and prospects can be used to delineate trends and polygons, much like chemical analyses of rocks. For example, one can plot a map of $\mathrm{U}$ mines or sites reported to contain fluorite. See also the derivative database developed by EPA (USEPA, 2006).

- Stream-water analyses might contain results for U, depending upon analytical methods used. Some of this data from the NURE program, the NAWQA (National Water Quality Assessment Program), and other U. S. Geological Survey programs stored in the National Water Information System (NWIS) may be useful. Uranium in stream water is not a simple guide to uranium deposits (as distinct from rocks in general), and factors such as $\mathrm{pH}$ and carbonate concentration should be considered. At the simplest level, a high value is a positive attribute.

- Airborne radiometric surveys and remote sensing surveys provide geochemical information, but are traditionally considered to be geophysical methods.

\section{Geophysics}

No geophysical parameter measures uranium directly, but many methods yield useful information that enhances geologic interpretations, especially for features at depth. Electromagnetic geophysics are widely used in Canada, but only for specific targets (for example, graphite conductors in unconformity-type deposits), and the surveys are very detailed. For regional assessment, only regional-scale surveys, typically with flight spacings of about 1 mile, are generally available.

- Airborne gamma spectrometry surveys for potassium, uranium (equivalent $U$ ), and thorium (equivalent Th) such as produced for the NURE program have value in characterizing geology, and should be helpful in documenting belts of rhyolite. Some deposits were found in the first years of these surveys, but it is unlikely that undiscovered deposits remain undetected. Airborne spectrometry detects K-U-Th in only the upper few centimeters of rock or soil, where $\mathrm{U}$ commonly is leached by weathering processes. Strictly speaking, the gamma peak used to measure eU in aerial surveys is from a daughter (decay) product, ${ }^{214} \mathrm{Bi}$, and intermediate 
decay products can be lost, causing radioactive disequilibrium (Ward, 1981). Thus, measurements may be larger or smaller than the amount of $U$ actually present. Computer enhancement, as well as ratios such as U:Th, may be helpful. There are several compilations of gamma ray spectrometric data (Duval and Riggle, 1999).

- Airborne magnetic data and models may be useful in defining structures in volcanics, especially calderas (Klein and Bankey, 1992). Low values should be examined carefully for evidence of alteration (pyritization of magnetite) or larger volumes of felsic volcanics relative to mafics. Magnetic surveys showing regions of rock alteration are useful over sulfidized basalt similar to rocks at the Aurora deposit. High-resolution magnetic surveys have been used to search for destruction of detrital magnetite in sandstone-uranium environments .

- Gravity data and models, including those developed during previous studies, could help refine caldera structures, including possible intrusions in the subsurface. Models at district scale (about 1:50,000) may be most productive and used for areas deemed favorable by other criteria.

- Remotely-sensed data for rock alteration should be useful, especially spectra sensitive to iron oxides (limonite) that form in weathered pyrite. Much of the alteration associated with volcanogenic uranium deposit is not intense or diagnostic of uranium, but U-pyrite association may be amenable to airborne mapping. This method probably should be used when other positive features have been found, allowing the interpretation to be done at a relatively larger scale such as 1:100,000. If modern high-resolution data such as AVIRIS is not available, the older LANDSAT data (ca. 1980) may be useful.

\section{Other Databases}

Climate databases and maps might be useful. The beneficial influence of wet climate on meteoric water recharge and hydrothermal circulation was discussed earlier ( $\mathrm{p}$. 49). Researchers of epithermal systems accept the importance of wet climate in oreforming processes and, while not proven for volcanogenic uranium deposit systems, rainfall may be an important criterion. Data compiled from paleo-biological and paleontological reports could prove helpful in identifying times and regions of wet climate. Timing of wet episodes should be compared with the age of thermal events and volcanic deposits.

Maps of oil and gas fields could suggest areas of potential reductants for uranium. There are many sources of this information, such as the 2007 assessment of the Eastern Great Basin (U. S. Geological Survey, 2007), or state coverage (Nevada; Davis, 2008). This may be one of the better ways to predict areas with potential for reductants; the concept was discussed as item 8 in the "Geology" section under the "Quantitative Assessment Criteria" heading. 


\section{Links to Other Assessments}

As discussed in earlier sections, the geology and geochemistry of volcanogenic uranium deposits has much in common with several other types of mineral deposits. Volcanic-hosted mineral deposits of interest include epithermal gold (fig. 2; Mosier and others, 1986), Spor Mountain-type Be (model in preparation), and rhyolite-hosted Sn (Reed and others, 1986). The permissive tracts for these or other deposit types in the 1996 National Mineral Resource Assessment (Ludington and Cox, 1996) serve as a starting point for future assessments.

\section{Suggestions for Further Work}

\section{Comparison with Epithermal Processes}

Volcanogenic uranium deposits and epithermal deposits have similarities and differences: for example, uranium systems are more oxidizing at the transport stage. The transport and deposition mechanisms for uranium clearly differ from those for base metals and gold. Are the differences due to sources, or are they due to different paths of fluid composition evolution? Are the analogies between volcanogenic and epithermal deposits helpful for assessment and exploration, or misleading? The Schwartzwalder vein uranium deposit (Wallace and Whelan, 1986) may be instructive as an intermediate variety.

Hydrogeochemical or reaction path modeling has been used to test concepts and refine mechanisms in hydrothermal ore systems (Reed and Spycher, 1985; Plumlee and others, 1994; Haynes and others, 1995) and could be a good way to test transport and deposition mechanisms in uranium systems. Hydrogeochemical models of unconformitytype deposits (Raffensperger and Garven, 1995; Komninou and Sverjensky, 1996) and Pocos de Caldas (Cathles and Shea, 1991) provided new perspectives and suggestions for new uranium research. Such modeling would be a good way to compare and contrast volcanic-associated epithermal and uranium systems. With effective interaction between geochemists and geologists, this desktop modeling could refine assessment criteria and suggest more specific queries for databases.

\section{Refine Rhyolite Magmatism}

Can the petrogenesis and tectonic setting of silicic and alkalic volcanism (Castor and Henry, 2000; Rytuba and Conrad, 1981; Cuney and Kyser, 2009) be refined to narrow magmatic conditions of uranium sources? What are optimum variables, and is water content and oxidation state important? Are there ages and compositions of crust that are conducive to U-rich magmas? Is uranium transported by magmatic-hydrothermal fluids, as in base metals in porphyry systems (but different complex ions), or does uranium stay in magma through crystallization, awaiting later leaching and transport processes? New information and concepts, reviewed by Cuney and Kyser (2009), are helpful but are not specific to terrane in the United States.

One thrust of this task should be mineralogical studies of samples analyzed for $U$ and Th, especially Fe-silicates and Fe-oxides that could provide estimates of water 
content and oxygen fugacity. These descriptions and petrochemical framework would then make database searches more specific for promising volcanic source rocks. It would be easy to search databases for "rhyolite and biotite." Also, petrographic mapping of U residence, using fission track methods, could refine the hypothesis of Leroy and GeorgeAniel (1992) that $\mathrm{U}$ in glassy matrix is more important than composition for fertility in volcanic rocks.

\section{Evaluate Role of Sulfate-rich Brines}

Brines are important, physically and chemically, in forming several kinds of base metal deposits as well as several kinds of uranium deposits, but they are not known to play a role in forming volcanogenic uranium deposits. A role for transport and deposition of volcanogenic uranium by chloride-sulfate-rich brines is proposed here by analogy and theory. The empirical association of many kinds of uranium deposits with evaporites was noted 28 years ago (Nash and others, 1981) but little progress has been made to explain this association. Calculations that sulfate-rich brines are oxidizing and favorable for uranium transport need refinement by geochemical and stable isotopic analyses.

\section{Refine Sulfur Reduction Mechanisms}

Details of the deposition of uranium are not well established for most of the important deposits reviewed here. Conditions of uranium deposition at Marysvale were studied in detail (Cunningham and others, 1998), but these deposits may not be typical of volcanogenic systems. Reduction processes should be studied for other volcanogenic uranium deposits. The practical goal of these studies should be prediction of favorable settings or traps. Is sulfur the key, as I have postulated, and can the pathways of possible sulfide reductants be predicted from geologic and geochemical maps? Is there a geophysical tool that can detect these traps from a distance?

Oilfields are linked to uranium deposits in South Texas and shown to be a source of hydrogen sulfide to make sulfide minerals or act as a reductant (Goldhaber and others, 1978). The Lodeve deposit shows a rare mix of lacustrine and volcaniclastic rocks, and bitumen and petroleum of several types are associated with both syngenetic and remobilized uranium deposits. Might these reduction mechanisms operate in other volcanic settings? In the Great Basin, Tertiary volcanic systems overlie marine carbonateshale sequences known to produce petroleum. Heavy-oil deposits are known around the world to be produced by major meteoric flow systems of long duration (by biodegradation of light oil); heavy oil deposits are known in the Great Basin. The meteoric fluid flow into these shallow oil deposits could interact with volcanic rocks to create a "new" type of uranium deposit with a source or trap in volcanic rocks. Speculatively, these new reduction mechanisms have the potential to create deposits that are larger in size than traditional volcanogenic deposits.

\section{Hydrothermal Mobilization of Uranium in Volcaniclastic Strata}

There is some evidence, and much conjecture, for hydrothermal mobilization and upgrading in the Lodeve, France, and Arlit, Niger, districts, discussed previously. The 
most specific fluid-inclusion, trace element chemistry, and petrographic data are for Arlit (Pagel and others, 2005), but there is little documentation. There are very little data of this type, and few studies have been attempted or published. The recently introduced "tectonolithologic" class (IAEA, 2008; Cuney and Kyser, 2009) is a conceptual hybrid that includes aspects of sandstone, volcanogenic, and unconformity-type that encourages new thinking during resource assessment or exploration.

Large volumes of carbonaceous volcaniclastic rock in lacustrine basins are highly enriched in uranium, to the point that they are called low-grade deposits. There will be mechanisms to mobilize this uranium into high-grade deposits of another structural style, presumably not far distant. Several lines of evidence show that the carbonaceous U ores of the Morrison Formation, Grants mineral belt have been altered by much younger groundwaters and U remobilized into "stack" orebodies (Granger and others, 1961). How does this happen and can it be predicted by tectonics that change groundwater regimes? Might bacteria be involved in bio-oxidation and have other processes escaped our consideration? What can we learn from the redistribution into high-grade deposits at Lodeve and Grants in which the precursor was carbonaceous?

\section{Refine Post-ore Stability of Deposits}

Quadrivalent and hexavalent $U$ minerals are more soluble than most ore minerals, as shown by the delicate balance in most depositional traps. Destruction of deposits by oxidizing groundwater is a real problem. Preservation of $U$ deposits is more problematic than most ore types, with some experts proposing that post-ore tectonic stability is required for preservation (Finch and Davis, 1985). Is destruction of deposits a factor that should be considered in assessment of tectonically active regions like the Great Basin? Or, can some kind of tectonism, such as uplift and minor tilt, enrich a deposit? Can such tectonism drive ore-forming processes in low-grade vitric tuffs or lacustrine sediments?

\section{Refine Assessment Concepts and Practices}

Assessments of undiscovered resources are de facto unverifiable, but they can be made more coherent and explained better to both scientists and laymen. There are substantial differences of perspective among experienced USGS mineral resource assessment scientists. There are fundamental differences among assessments driven by a grade-tonnage model, a specific ore deposit model, an ore system model, or a geologic framework. Each has its merits, and with collaboration the best parts of each perspective could be added into an integrated approach. The framework approach is suggested here for regional assessment of large areas because the assessment team should make the most of generalized data; little is known about the postulated deposit or it would have been discovered.

Better methods and vocabulary are suggested to express confidence levels or uncertainty in the assessment, especially in a regional assessment that makes estimates from databases that do not contain all of the diagnostic data that are collected at prototype ore deposits. How does a lack of data in a frontier area influence estimates? Helpful comments have been made about uncertainty (Singer, 2007) from a statistical perspective of range in estimates. Geologists should find a method to express their confidence in the 
quality and quantity of available data. Rules can be written to automate computations in a GIS, to make assessments more consistent. Artificial intelligence programs have been written in the past, as in the Prospector system (Duda, 1980). The goal is to make the assessments more reliable and reproducible than those based on "art" and "experience." However, it is clear that assessments will always be subjective, if any one part is subjective.

\section{Concluding Remarks}

This report conveys numerous descriptions and concepts. I hope that the descriptions provide a reliable foundation and the concepts a measure of understanding, in preparation for the difficult task of resource assessment. The volcanic environment and associated uranium deposits are emerging as very promising after decades of neglect. Looking back at the many ore environments that I have been able to study over more than 40 years, I can say that descriptive and genetic work on volcanogenic uranium deposits lags. I have been fortunate to be able to work closely with research and exploration geoscientists who have raised the understanding of epithermal precious metal deposits and sandstone-type uranium deposits to new levels. Many colleagues have shaped the way I look at ore deposit formation and assessment, especially David John, Steve Ludington, and Alan Wallace (epithermal deposits) and Sam Adams, Marty Goldhaber, and Harry Granger (uranium deposits).

Geoscientists who undertake assessments (or exploration) should have vision. Images reported here of most volcanogenic uranium deposits are incomplete and understated, but there is optimism in the more recent snapshots of deposits in Asia, especially as reported by Michel Cuney (Cuney and Kyser, 2009) from his unique global experience. It is my belief that one's vision of volcanogenic uranium deposits is improved by knowledge of thoroughly studied analogs: epithermal gold deposits and sandstone uranium deposits. There are dangers in this approach that may not be adequately conveyed here. Where or when is the analogy inappropriate? Advances in understanding of tectonics, volcanism, and hydrothermal processes associated with epithermal gold deposits provide bold views of a big picture; differences for uranium should be identified because the gold systems are notoriously low in U. Hydrologic and geochemical processes defined for sandstone-type deposits provide insights of possibilities and details for volcanogenic uranium that I think are more reliable than the sparse experimental work at elevated temperatures.

For volcanogenic uranium resources in the United States there may be a paradox. Recent discoveries of large deposits in Asia suggest that there should be some large deposits in the United States. Uranium exploration in the United States seems to have been more widespread than in most parts of the world, but has it been done with the right vision? Thousands of prospects were reported prior to 1960, but the few that were mined were small. The example of Streltsovskoye caldera is sobering: this $20 \mathrm{~km}$ diameter caldera was known (as are many in the United States), but uranium deposits were not discovered until after more than 10 years of exploration beneath the false surface anomalies (Cuney and Kyser, 2009). How many similar blind deposits might there be in the United States, on structures not drilled to sufficient depth? I suggest the use of 
analogs in other regions and other deposits types for a better perspective in assessment and exploration.

I have speculated that larger volcanogenic uranium deposits could form by processes defined by research on epithermal gold, unconformity-type $U$, and sandstonetype systems. I am optimistic that large deposits can be found in settings where largevolume fluid flow has occurred in zones of fracture or bed permeability, aided by thermal or gravitational drive. This may be wishful thinking, especially if correspondingly effective depositional traps do not exist. The required research and field studies are challenges for the next generation.

\section{Acknowledgments}

Ideas expressed in this report reflect discussions and fieldwork with countless geologists over more than 40 years. Discussions with colleagues in the U.S. Geological Survey have been particularly helpful. Reviews of early versions of this report, provided by Ed duBray, Poul Emsbo, Rich Goldfarb, Greg Spanski, and Alan Wallace, all of the USGS, helped with organization, logic, and focus. Rigorous and challenging reviews by George Breit and David Lindsey, USGS, greatly improved the science and clarity. The author acknowledges with thanks the assistance of named and unnamed colleagues The compilation and research reported here were done under a contract with the USGS Office of Mineral Resources, Updated National Mineral Resources Project.

\section{References}

Adams, S.S., and Cramer, R.T., 1986, Data-process-criteria model for roll-type uranium deposits, in Geological environments of sandstone-type uranium deposits: Vienna, International Atomic Energy Agency, Tecdoc-328, p. 383-399.

Adams, S.S., Curtis, H. Starr, Hafen, Preston L., and Salek-Nejad, Hussein, 1978, Interpretation of postdepositional processes related to the formation and destruction of the Jackpile-Paguate uranium deposit, northwest New Mexico: Economic Geology, v. 73, p.1633-1654.

Alexandre, P., Kyser, Kurt, Polito, E., and Thomas, David, 2005, Alteration mineralogy and stable isotope geochemistry of Paleoproterozoic basement-hosted unconformity-type uranium deposits in the Athabasca Basin, Canada: Economic Geology, v. 100, p. 1547-1563.

Allis, R.G., 1990, Geophysical anomalies over epithermal systems: Journal of Geochemical Exploration, v. 36, p. 339-374. 
Areva, 2009, AREVA in Niger: Areva, 19 p., accessed at http://niger.areva.com/niger_home/liblocal/docs/AREVA\%20au\%20Niger\%20j anvier\%2009\%20version\%20anglaise.pdf.

Bagby, W.C., 1986, Descriptive model of volcanogenic U, in Cox, D.P., and Singer, D.A., eds., Mineral Deposit Models: U.S. Geological Survey Bulletin 1693, p. 162.

Bain, J.H.C., 1977, Uranium mineralization associated with late Paleozoic acid magmatism in northeastern Queensland: Bureau of Mineral Resources Journal of Australian Geology and Geophysics, v. 2, p. 137-147.

Barton, P.B., Bethke, P.M., and Roedder, Edwin, 1977, Environment of ore deposition in the Creede mining District, San Juan Mountains, Colorado:- III, Progress toward interpretation of the chemistry of the ore-forming fluid for the $\mathrm{OH}$ vein: Economic Geology, v. 72, p. 1-24.

Barton, P.B., Brew, D.A., Ayuso, R.A., Gamble, B.M., John, D.A., Ludington, S.D., Lindsey, D.A., Force, E.R., Goldfarb, R.J., and Johnson, K.M., 1995, Recommendations for assessments of undiscovered mineral resources: U.S. Geological Survey Open-File Report 95-82, 139 p.

Becraft, G. E., and Weis, P. F, 1963, Geology and mineral deposits of the Turtle Lake quadrangle, Washington: U.S. Geological Survey Bulletin 1131, 73 p.

Berger, B.R., and Bonham, H.F., 1990, Epithermal gold-silver deposits in the western United States-Time-space products of evolving plutonic, volcanic, and tectonic environments: Journal of Geochemical Exploration, v. 36, p. 103-142.

Best, M. G., and Christiansen, E.H., 2001, Igneous petrology: London, Blackwell Science, $458 \mathrm{p}$.

BHP Billiton, 2008, Annual Report; see p. 70; available as pdf.

Bowden, Peter, 1985, The geochemistry and mineralization of alkaline ring complexes in Africa (a review): Journal of African Earth Sciences, v. 3, p. 17-37.

Burnham, C.W., 1997, Magmas and hydrothermal fluids, in Barnes, H.L., ed., Geochemistry of Hydrothermal Ore Deposits (3d ed.): New York, John Wiley and Sons, p. 63-124.

Burt, D.M., Sheridan, M.F., Bikun, J.V., and Christiansen, E.H., 1982, Topaz rhyolitesDistribution, origin, and significance for exploration: Economic Geology, v. 77, p. 1818-1836.

Cai, Chunfang, Dong, Hailiang, Li, Hongtao, Xiao, Xinjian, Ou, Guanxi, and Zhang, Chunming, 2007, Mineralogical and geochemical evidence for coupled bacterial 
uranium mineralization and hydrocarbon oxidation in the Shashagetai deposit, NM China: Chemical Geology, v. 236, p. 167-179.

Candela, P.A., 1997, A review of shallow ore-related granites-Textures, volatiles, and ore metals: Journal of Petrology, v. 38, p. 1619-1633.

Casadevall, Tom, and Ohmoto, Hiroshi, 1977, Sunnyside Mine, Eureka mining district, San Juan County, Colorado - Geochemistry of gold and base metal deposition in a volcanic environment: Economic Geology, v. 72, p. 1285-1320.

Castor, S.B., and Berry, M.R., 1981, Geology of the Lakeview uranium district, Oregon, in Goodell, P.C., and Waters, A.C. eds., Uranium in Volcanic and Volcaniclastic Rocks: American Association of Petroleum Geologists Studies in Geology, v.13, p. $55-62$.

Castor, S.B. and Henry, C.D., 2000, Geology, geochemistry, and origin of volcanic rockhosted uranium deposits in northwestern Nevada and southeastern Oregon, US: Ore Geology Reviews, v. 16, p. 1-40.

Cathles, L.M. III, 1977, An analysis of cooling of intrusives by groundwater convection which includes boiling: Economic Geology, v. 72, p. 804-826.

Cathles, L.M. III, and Shea, M.E., 1992, Near-field high temperature transportEvidence from the genesis of the Osamu Utsumi uranium mine, Pocos de Caldas alkaline complex, Brazil: Journal of Geochemical Exploration, v. 45, p. 565-603.

Cazoulet, M., 1985, Geologic environment of uranium deposits in Carboniferous and Jurassic sandstones of the western margin of the Air Mountains, Republic of Niger: Vienna, International Atomic Energy Agency, Geological environments of sandstone-type uranium deposits, Tecdoc-328, p. 247-264.

Chabiron, Aliouka, Alyoshin, A.P., Cuney, M., Deloule, E., Golubev, V.N., Velithkin, V.I., and Poty, B., 2001, Geochemistry of the rhyolite magmas from the Streltsovka caldera (Transbaikalia, Russia) - A melt inclusion study: Chemical Geology, v. 175, p. 272-290.

Chabiron, Aliouka, Cuney, Michel, and Poty, Bernard, 2003, Possible uranium sources for the largest uranium district associated with volcanism-The Streltsovka caldera (Transbaikalia, Russia): Mineralium Deposita, v. 38, p. 127-140.

Chenoweth, W.L, 1991, United States production of uranium and vanadium, table 1 in Shawe, D.R., Nash. J.T., and Chenoweth, W.L., 1991, Uranium and Vanadium deposits, in Gluskoter, H.J., Rice, D.D., and Taylor, R.B., eds., Economic Geology, U.S.: Boulder, Colorado, Geological Society of America, The Geology of North America, v. P-2, p. 103-124. 
Christiansen, E.H., 2005, Contrasting processes in silicic magma chambers: evidence from very large volume ignimbrites: Geology Magazine, v. 142, p. 669-681.

Christiansen, E.H., Sheridan, M.F., and Burt, D.M., 1986, The geology and geochemistry of Cenozoic topaz rhyolites from the western United States: Geological Society of America Special Paper 205, 82 p.

Christiansen, E.H., and Lee, D.E., 1986, Fluorine and chlorine in granitoids from the Basin and Range province, western United States: Economic Geology, v. 81, p. 1484-1494.

Comte, D., Blanchere, H., and Varlet, M., 1986, Geological environment of the uranium deposits in the Permian of Lodeve basin, France, in Geological environments of sandstone-type uranium deposits: Vienna, International Atomic Energy Agency, Tecdoc-328, p. 69-82.

Cox, D.P., and Singer, D.A., eds., 1986, Mineral deposit models: U.S. Geological Survey Bulletin 1693, 393 p.

Cuney, Michel, 1978, Geologic environment, mineralogy, and fluid inclusions of the Bois Noirs-Limouzat uranium vein, Forez, France: Economic Geology, v. 73, p. 15671610.

Cuney, Michel, 2009, The extreme diversity of uranium deposits: Mineralium Deposita, v. 44 , p. 3-9.

Cuney, Michel, Marignac, Christian, and Weisbrod, Alain, 1992, The topaz-lepidolite albite granite (Massif Central, France) - The disseminated magmatic Sn-Li-TaNb-Be mineralization: Economic Geology, v. 87, p. 1776-1794.

Cuney, Michel, and Kyser, Kurt, 2009, Recent and not-so-recent developments in uranium deposits and implications for exploration: Mineralogical Association of Canada, Short Course Series Volume 39, 257 p. [A very complete review of all major kinds of uranium deposits, very thorough treatment of geochemistry, with 16 pages on volcanic-related deposits.]

Cunningham, C.G., Rasmussen, J.D., Steven, T.A., Rye, R.O., Rowley, P.D., Romberger, S.B., and Selverstone, J., 1998, Hydrothermal uranium deposits containing molybdenum and fluorite in the Marysvale volcanic field, west-central Utah: Mineralium Deposita, v. 33, p. 477-494.

Curtis, Lawrence, 1981, Uranium in volcanic and volcaniclastic rocks-examples from Canada, Australia, and Italy, in Goodell, P.C., and Waters, A.C., eds., Uranium in volcanic and volcaniclastic rocks: American Association of Petroleum Geologists, Studies in Geology v. 13, p 37-53. 
Davidson, G.J., Paterson, H., Meffre, S., and Berry, R.F., 2007, Characteristics and origin of the Oak Dam East breccia-hosted iron-oxice $\mathrm{Cu}-\mathrm{U}-(\mathrm{Au})$ deposit-Olympic Dam region, Gawler Craton, South Australia: Economic Geology, v. 102, p. 1471-1498.

Davis, D.A., 2008, Oil and Gas, in The Nevada Mineral Industry 2007: Nevada Bureau of Mines and Geology, Special Publication MI-2007, p. 155-169.

Donatienne, Derome, Cathelineau, Michael, Cuney, Michel, Fabre, Cecile, and Lhomme, Therese, 2005, Mixing of sodic and calcic brines and uranium deposition at McArthur River, Saskatchewan, Canada - A raman and laser-induced breakdown spectroscopic study of fluid inclusions: Economic Geology, v. 100, p. 1529-1545.

Drummond, S.E., and Ohmoto, Hiroshi, 1985, Chemical evolution and mineral deposition in boiling hydrothermal systems: Economic Geology, v. 80, p. 126147.

Duda, R.O., 1980, The Prospector system for mineral exploration: Menlo Park, California, Stanford Research Institute Final report, Project 8172, 120 p.

Duval, J.S and Riggle, F.E., 1999, Profiles of gamma-ray and magnetic data from aerial surveys over the conterminous United States: U.S. Geological Survey Digital Data Series Report DDS-0031. [3 CD-ROMs].

Ebert, S.W., and Rye, R.O., 1997, Secondary precious metal enrichment by steam-heated fluids in the Crowfoot-Lewis hot spring gold-silver deposit and relation to paleoclimate: Economic Geology, v. 92, p. 578-600.

Fehn, U., Cathles, L.M., and Holland, H.D, 1978, Hydrothermal convection and uranium deposits in abnormally radioactive plutons: Economic Geology, v. 73, p. 15561566.

Finch, W.I, and Davis, J.F., 1985, Sandstone-type uranium deposits-An introduction, in Geological environments of sandstone-type uranium deposits: Vienna, International Atomic Energy Agency, Tecdoc-328, p. 11-20.

Fleischer, R.L., Price, P.B., and Walker, R.M., 1966, Nuclear tracks in solids: Scientific American, v. 220, p. 30-39.

Fournier, R.O., 1985, The behavior of silica in hydrothermal solutions, in Berger, B.R. and Bethke, P.M., eds., Geology and geochemistry of epithermal systems: Reviews in Economic Geology, v. 2, p. 45-62.

French, D.E., 1983, Origins of oil in Railroad Valley, Nye County, Nevada: American Association Petroleum Geologist Bulletin, v. 67, p. 1337. 
Fuchs, Y., and Maury, R., 1995, Borosilicate alteration associated with U-Mo-Zn and Ag-Au-Zn deposits in volcanic rocks: Mineralium Deposita, v. 30, p. 449-459.

Full, R.P., and Grantham, R.M., 1968, Ore deposits of the Republic Mining District, Ferry County, Washington: Ore Deposits of the United States, 1933-1967, American Institute of Mining and Metallurgical Engineers, Inc., p. 1495-1510.

Gandhi, S.S., 1978, Geological setting and genetic aspects of uranium occurrences in the Kaipokok Bay-Big River area, Labrador: Economic Geology, v. 73, p. 14921522.

Garside, L.J., 1973. Radioactive mineral occurrences in Nevada: Nevada Bureau of Mines and Geology, Bulletin 81, 121 p.

Garven, Grant, and Raffensperger, J.P., 1997, Hydrogeology and geochemistry of ore genesis in sedimentary basins, in Barnes, H.L., ed., Geochemistry of hydrothermal ore deposits (3d ed.): New York, John Wiley and Sons, p. 125-190.

George-Aniel, Brigitte, Leroy, J.L., and Poty, Bernard, 1991, Volcanogenic uranium mineralizations in the Sierra Pena Blanca District, Chihuahua, Mexico-Three genetic models: Economic Geology, v. 86, p. 233-248.

Gibson, P.E., and Wood, S.A., 1997, Mineralogy, geochemistry and mobility of the REE and thorium at Lemhi Pass, Idaho: Abstracts with Programs, Geological Society of America, v. 29, no. 6, p. 50.

Goldhaber, M.B., 1983, Experimental study of metastable sulfur oxyanion formation during pyrite oxidation at $\mathrm{pH}$ 6-9 and $30 \mathrm{deg} \mathrm{C}$ : American Journal of Science, v. 282, p. 193-217.

Goldhaber, M.B, Reynolds, R.L., and Rye, R.O, 1978, Origin of a South Texas roll-type uranium deposit-II. Sulfide petrology and sulfur isotopes: Economic Geology, v. 73, p. $1690-1705$.

Goldhaber, M.B., Reynolds, R.L., Campbell, J.A., Wanty, R.B., Grauch, R.I., and Northrup, H.R., 1990, Genesis of the tabular-type vanadium-uranium deposits of the Henry Basin, Utah-Part II. Mechanisms of ore and gangue mineral formation at the interface between brine and meteoric water: Economic Geology, v. 85, p. 215-269.

Goodell, P. C., 1981a, Geology of the Pena Blanca uranium deposits, Chihuahua, Mexico: American Association of Petroleum Geologists Studies in Geology, v. 13, p. 275-291.

Goodell, P.C., 1981b, A model for the formation of uranium deposits in volcanic rocks: Association of Petroleum Geologists Bulletin, v. 65, p. 931. 
Granger, H.C., Santos, E.S., Dean, B.G., and Moore, F.G., 1961, Sandstone-type uranium deposits at Ambrosia Lake, New Mexico-An interim report: Economic Geology, v. 56, p. 1179-1209.

Granger, H.C., and Warren, C.G., 1969, Unstable sulfur compounds and the origin of roll-type uranium deposits: Economic Geology, v. 64, p. 160-171.

Granitto, Matthew, Yager, Douglas, and Hofstra, A.H., 2005, Geochemical data for the Great Basin-A subset of the U.S. Geological Survey new National Geochemical Database: Abstracts with Programs, Geological Society of America, v. 37, no. 7, p. 380 .

Groves, D.I., Condie, K.C., Goldfarb, R.J., Hronsky, J.M.A., and Vielreicher, R.M., 2005, Secular changes in global tectonic processes and their influence on the temporal distribution of gold-bearing mineral deposits: Economic Geology, v. 100, p. 203-224.

Gustafson, L.B., and Williams, Neil, 1981, Sediment-hosted stratiform deposits of copper, lead, and zinc, in Economic Geology Seventy-Fifth Anniversary Volume, p. 139-178.

Hanor, J.S., 1979, The sedimentary genesis of hydrothermal fluids, in H.L. Barnes, ed., Geochemistry of Hydrothermal Ore Deposits (2d ed.): New York, John Wiley and Sons, p. 137-172.

Hardie, L.A., and Eugster, H.P., 1970, The evolution of closed basins: Mineralogical Society of America, Special Paper 3, p. 273-290.

Harris, D.P., 1984, Mineral resource appraisal; mineral endowment, resources, mineral endowment, resources, and potential supply_Concepts, methods, and cases: Oxford, Oxford University Press, 445 p.

Hay, R.L. and Sheppard, R.L., 1977, Zeolites in open hydrologic systems, in Mineralogy and geology of natural zeolites: Mineralogical Society of America Short Course Notes, v. 4, p. 93-102.

Hayba, D.O., 1997, Environment of ore deposition in the Creede mining district, San Juan Mountains, Colorado-Part V. Epithermal mineralization from fluid mixing in the $\mathrm{OH}$ vein: Economic Geology, v. 92, p. 29-44.

Haynes, D.W., Cross, K.R., Bills, R.T., and Reed, M.H., 1995, Olympic Dam ore genesis-A fluid-mixing model: Economic Geology, v. 90, p. 281-307. 
Heald, Pamela, Foley, N.K., and Hayba, D.O., 1987, Comparative anatomy of volcanichosted epithermal deposits - Acid sulfate and adularia-sericite types: Economic Geology, v. 82, p. 1-26.

Hildreth, Wes, 1979, The Bishop Tuff, evidence for the origin of compositional zonation in silicic magma chambers: Geological Society of America Special Paper 180, p. 43-75.

Henley, R.W., and Ellis, A.J., 1983, Geothermal systems ancient and modern; a geochemical review: Earth Science Reviews, v. 19, p. 1-50.

Henry, C. D., and Duex, T.W., 1981, Uranium in digenesis of the Pruett, Duff, and Thascotal Formations, Trans-Pecos, Texas, in Goodell, P.C., and Waters, A.C., eds., Uranium in Volcanic and Volcaniclastic Rocks: American Association of Petroleum Geologists Studies in Geology, v. 13, p. 167-179.

Hoffman, J.D., Buttleman, K.P., Ambroziak, R.A., and Cook, C.A., 1994, National geochemical data base-National uranium resource evaluation data for the conterminous United States: U.S. Geological Survey Digital Data Series Report DDS-0018A. [CD-ROM].

Hostetler, P.B., and Garrels, R.M., 1962, Transportation and precipitation of uranium at low temperatures, with special reference to sandstone-type uranium deposits: Economic Geology, v. 52, p. 137-167.

International Atomic Energy Agency, 2008, Uranium 2007-Resources, production, and demand ("Red Book") (23d ed.): Paris, Joint Report of the Organization for Economic Co-organization and Development Nuclear Energy Agency and the International Atomic Energy Agency. [See also the database at the website: http://www-nfcis.iaea.org/UDEPO/UDEPOMain.asp].

Irvine, R.J., and Smith, M.J., 1990, Geophysical exploration for epithermal gold deposits: Journal of Geochemical Exploration, v. 36, p. 375-412.

Ischukova, L.P., 1997, The Streltsovskoye uranium district: Vienna, International Atomic Energy Agency, Tecdoc-961, p. 237-250.

John, D.A., 2001, Miocene and early Pliocene epithermal gold-silver deposits in the northern Great Basin, Western United States-Characteristics, distribution, and relationship to magmatism: Economic Geology, v. 96, p. 1827-1853.

Keppler, Hans, and Wylie, P. J., 1991, Partitioning of Cu, Sn, Mo, W, U, and Th between melt and aqueous fluid in the system haplogranite- $\mathrm{H}_{2} \mathrm{O}-\mathrm{HCl}$ and happlogranite$\mathrm{H}_{2} 0-\mathrm{HF}$ : Contributions to Minerology and Petrology, v. 109, p. 139-150. 
Klein, D.P., and Bankey, V., 1992, Geophysical model of Creede, Comstock, Sado, Goldfield and related epithermal precious metal deposits, in Geophysical Expression of Selected Mineral Deposit Models: U.S. Geological Survey OpenFile Report, 92-557, p. 98-106.

Komninou, A., and Sverjensky, D.A., 1996, Geochemical modeling of the formation of an unconformity-type uranium deposit: Economic Geology, v. 91, p. 590-606.

Kotzer, T.G., and Kyser, T.K., 1995, Paragenesis of the Proterozoic Athabasca Basin, northern Saskatchewan, Canada, and its relation to diagenesis, hydrothermal uranium mineralization, and paleohydrology: Chemical Geology, v. 120, p. 4590.

Langella, A., Cappelletti, P., and de Gennaro, M., 2001, Zeolites in closed hydrologic systems, in D.L. Bish and D.W. Ming, eds., Natural Zeolites-Occurrence, properties, applications: Reviews in Mineralogy and Geochemistry, v. 45, p. 235 260.

Langmuir, Donald, 1978, Uranium solution-mineral equilibria at low temperatures with applications to sedimentary ore deposits: Geochimica et Cosmochimica Acta, v. 42 , p. 547-569.

Larter, Steve, Wilhelms, Arnd, Head, Ian, Koopmans, Martin, Aplin, Andy, Di Primio, Rolando, Zwach, Christian, Erdmann, Michael, and Telnaes, Nils, 2003, The controls on the composition of biodegraded oils in the deep subsurface-Part 1: biodegradation rates in petroleum reservoirs: Organic Geochemistry, v. 34, p. $601-613$.

Leroy, J.L., Aniel, Brigitte, and Poty, Bernard, 1987, The Sierra Pena Blanca (Mexico) and Meseta Los Frailles (Bolivia)_-The uranium concentration mechanisms in volcanic environment during hydrothermal processes: Uranium, v. 3, 211-234.

Leroy, J.L., and George-Aniel, Brigitte, 1992, Volcanism and uranium mineralisationsThe concept of source rock and concentration mechanism: Journal of Volcanology and Geothermal Research, v. 50, p. 247-272.

Lindsey, D.A., 1977, Geology of the Yellow Chief Mine, Thomas Range, Juab County, Utah, in Shawe, D.R., ed., Guidebook to the Mineral Deposits of the Central Great Basin: Nevada Bureau of Mines and Geology, Report, no. 32, p 65-68.

Lindsey, D.A., 1981, Volcanism and uranium mineralization at Spor Mountain, Utah, in Goodell, P.C., and Waters, A.C., eds., Uranium in volcanic and volcaniclastic rocks: American Association of Petroleum Geologists, Studies in Geology, v.13, p. 89-98. 
Lindsey, D.A., 1982, Tertiary volcanic rocks and uranium in the Thomas Range and northern Drum Mountains, Juab County, Utah: U.S. Geological Survey Professional Paper 1221, 71 p.

Loureiro, F.E.L., and Dos Santos, R.C., 1988, The intra-intrusive uranium deposits of Pocos de Caldas, Brazil: Ore Geology Reviews, v. 3, p. 227-240.

Loveley, D.R., and Phillips, E.J., 1992, Reduction of uranium by Desulfovibrio desulfuricans: Applied and Environmental Microbiology, v. 58, p. 850-856.

Ludington, Steve, Cox, Dennis, and McCammon, B., eds., 1996, Data base for a National mineral-resource assessment of undiscovered deposits of gold, silver, copper, lead, and zinc in the Conterminous United States: U.S. Geological Survey, OpenFile Report 96-96 (CD-ROM, unpaginated).

Ludington, S.D., Cox, D.P., Leonard, L.R., and Moring, B.C., 1996, Cenozoic volcanic geology of Nevada: Nevada Bureau of Mines and Geology, Open-File Report 962. [Text and plate]

Ludwig, K.R., Nash, J.T, and Naesser, C.W., 1981, U-Pb isotope systematics and age of uranium mineralization, Midnite Mine, Washington: Economic Geology, v. 76, p. $89-110$.

Luedke, R.G., and Smith, R.L., 1984, Map showing distribution, composition, and age of late Cenozoic volcanic centers in the western conterminous United States: U.S. Geological Survey, Miscellaneous Investigations Series, Report I-1523. [1 sheet].

McCammon, R.B., 1992, Numerical mineral deposit models, in J. D. Bliss, ed., Developments in mineral deposit modeling: U.S. Geological Survey Bulletin 2004, p. 6-12.

McKay, A.D., and Miezitis, Yanis, 2001, Australia's uranium resources, geology and development of deposits: Australian Geological Survey Organization-Geoscience Australia, Mineral Resource Report 1, 200 p. plus appendices.

McKibben, M.A., and Hardie, L.A., 1997, Ore-forming brines in active continental rifts, in Barnes, H.L., ed., Geochemistry of hydrothermal ore deposits (3d ed.): New York, John Wiley and Sons, p. 877-936.

Meyer, R.F., Attanasi, E.D., and Freeman, P.A., 2007, Heavy oil and natural bitumen resources in geological basins of the world: U.S. Geological Survey Open-File Report 2007-1084, accessed online at http://pubs.usgs.gov/of/2007/1084/.

Myers, Gregory, 2005, Technical report of the Aurora uranium project, Malheur County, Oregon, for Quincy Energy Corp., 81 p. [Available as pdf from: www.sedar.com/displaycompanydocuments.do?/lang=EN\&issuerno=00021197] 
Millard, Jr., H.T., 1976, Determination of uranium and thorium in USGS standard rocks by the delayed neutron technique: U.S. Geological Survey, Professional Paper 840 , p. 61-65.

Moine, Bernard, Ramambazafy, A., Rakotondrazafy, M., Cuney, M., de Perceval, P., 1997, The role of fluor-rich fluids in the transport of Th, Zr, Ti, and REE-An example from the granulites of South Madagascar: Proceedings European Current Research on Fluid Inclusions, v. 14, p. 209-210.

Mosier, D.L., 1986, Grade and tonnage model of volcanogenic U, in Cox, D.P., and Singer, D.A., eds., Mineral Deposit Models: U.S. Geological Survey Bulletin 1693, p. 162-164.

Mosier, D.L., Singer, D.A., and Berger, B.R., 1986, Descriptive model of Comstock epithermal veins, in Cox, D.P., and Singer, D.A., eds., Mineral Deposit Models: U.S. Geological Survey Bulletin 1693, p. 150.

Mottl, M.J., Holland, H.D., and Corr, R.F., 1979, Chemical exchange during hydrothermal alteration of basalt by seawater-II. Experimental results for Fe, Mn, and sulfur species: Geochimica et Cosmochimica Acta, v. 43, p. 869-884.

Moye, F.J., 1982, Eocene sanpoil volcanics of northeast Washington: Abstracts with Programs, Geological Society of America, v. 14, no. 6, p. 343.

Mueller, A., and Hallbach, P., 1983, The Anderson Mine (Arizona) —An early diagenetic uranium deposit in Miocene lake sediments: Economic Geology, v. 78, p. 275292.

Murowchick, J.B., and Barnes, H.L., 1986, Marcasite precipitation from hydrothermal solutions: Geochimica et Cosmochimica Acta, v. 50, p. 2615-2629.

Nash, J. T., 1988, Geology and geochemistry of the Pitch uranium mine area, Saguache County, Colorado: U.S. Geological Survey Bulletin 1797, 38 p.

Nash, J. T., 2005, Hydrogeochemical studies of historical mining areas in the Humboldt River Basin and adjacent areas, northern Nevada: U.S. Geological Survey Scientific Investigations Report, 2004-5236, [1 CD-ROM].

Nash, J.T., and Lehrman, N.J., 1975, Geology of the Midnite Mine area, Stevens County, Washington-A preliminary report: U.S. Geological Survey Open-File Report 75-402, $36 \mathrm{p}$.

Nash, J.T., Granger, H.C., and Adams, S.S., 1981, Geology and concepts of genesis of important types of uranium deposits, in Economic Geology Seventy-Fifth Anniversary Volume, p. 63-116. 
Nash, J.T., and Hahn, G.A., 1989, Strata bound Co-Cu deposits and mafic volcaniclastic rocks in the Blackbird mining district, Lemhi County, Idaho, in Boyle, R.W. Brown, A.C., Jefferson, C.W., Jowett, E. C. and Kirkham, R V, eds.: Geological Association of Canada Special Paper, v. 36, p. 339-356.

Nash, J.T., and Trudel, W.S., 1996, Bulk minable gold ore at the Sleeper Mine, NevadaImportance of extensional faults, breccia, framboids, and oxidation, in Geology and Ore Deposits of the American Cordillera Symposium, Reno-Sparks, Nevada, April 1995, Proceedings: Reno, Nevada, Geological Society of Nevada, p. 235256.

Olson, J.C., 1983, Geologic and structural maps and sections of the Marshall Pass mining district, Saguache, Gunnison, and Chaffee Counties, Colorado: U.S. Geological Survey Map I-1425, scale 1:24,000.

Ohmoto, Hiroshi, Mizukami, M., Drummond, S.E., Eldridge, S.E., Pisutha-Arnold, V., and Lenagh, T.C., 1983, Chemical processes of Kuroko formation, in Ohmoto, Hiroshi, and Skinner, B.J., eds., The Kuroko and related volcanogenic massive sulfide deposits: Economic Geology Monograph 5, p. 570-604.

Otton, J.K., 1985, Geologic environment of uranium in lacustrine host rocks in the western United States, in Geological environments of sandstone-type uranium deposits: Vienna, International Atomic Energy Agency Tecdoc 328, p. 229-241.

Pagel, Maurice, Cavellec, Sabine, Forbes, Pierre, Gerbaud, Olivier, Vergely, Pierre, and Wagani, Ibrahim, 2005, Uranium deposits in the Arlit area (Niger), in Mao, J. and Bierlein, M.P., eds., Mineral deposit research, Meeting the global challenge, Proceedings of the $8^{\text {th }}$ SGA Meeting in Beijing, China: Switzerland, Society for Geology Applied to Mineral Deposits, p. 303-305.

Pearson, R.C., and Obradovich, J. D., 1977, Eocene rocks in northeast WashingtonRadiometric ages and correlation: U.S. Geological Survey Bulletin 1433, 41 p.

Pehrrson, Sally, Galley, Alan, Corrigan, David, and Jefferson, Charlie, 2007, Influence of the world's first supercontinent on global metallotects-Nuna and the formation and preservation of Paleoproterozoic base metal and uranium deposits: Arizona Geological Society, Symposium Abstracts, Ores and Orogenesis, September, 2007.

Peiffert, Chantel, Nguyen-Trung, Chinh, and Cuney, Michel, 1996, Uranium in granitic magmas - Part 2. Experimental determination of uranium solubility and fluidmelt partition coefficients in the uranium oxide-haplogranite- $\mathrm{H}_{2} 0-\mathrm{NaX}(\mathrm{X}=\mathrm{Cl}$, F) system at $770{ }^{\circ} \mathrm{C}, 2$ kbar.: Geochimica et Cosmochimica Acta, v. 60, p. 15151529. 
Peters, S.G., Nash, J.T., John, D.A., and Theodore, T.G., 1996, Metallic mineral resources in the U.S. Bureau of Land Management's Winnemucca District and Surprise Resource area, northwest Nevada and northeast California: U.S. Geological Survey Open-File Report 96-712, 147 p.

Pichavant, Michel, Kontak, D.J., Herrera, J.V., and Clark, A.H., 1988, The MiocenePliocene Macusani volcanics, SE Peru: Contributions to Mineralogy and Petrology, v. 100, p. 300-324.

Plant, Jane, Simpson, P.R., Smith, Barry, and Windley, B.F., 1999, Uranium ore deposits: products of the radioactive earth, in P.C. Burns and Robert Finch, eds., Uranium-Mineralogy, geochemistry, and the environment: Mineralogical Society of America, Reviews in Mineralogy, v. 38, p. 255-320.

Plumlee, G.P., Leach, D.L., Hofstra, A.H., Landis, G.P., Rowan, E.L., and Viets, J.G., 1994, Chemical reaction path modeling of ore deposition in Mississippi Valleytype $\mathrm{Pb}-\mathrm{Zn}$ deposits of the Ozark Region, U.S. Midcontinent: Economic Gelogy, v. 89 , p. 1361-1383.

Plut, F.W., 1979, Geology of the Apex uranium mine near Austin, Nevada: Rocky Mountain Association of Geologists, Basin and Range Symposium, p. 413-420.

Poty, Bernard, Leroy, J., Cathelineau, M., Cuney, M., Friedrich, M., Lespinasse, M, and Turpin, L., 1986, Uranium deposits spatially related to granites in the French part of the Hercynian Orogen: Vein Type Uranium Deposits, International Atomic Energy Agency, Tecdoc-361, p. 215-246.

Preto, V.A., 1978, Setting and genesis of uranium mineralization at Rexspar: Canadian Institute of Mining and Metallurgy Bulletin, v. 70, p. 93-100.

Raffensperger, J.P., and Garven, Grant, 1995, The formation of unconformity-type uranium ore deposits - 2. Coupled hydrogeochemical modeling: American Journal of Science, v. 295, p. 639-696.

Reed, B.L., Duffield, W., Ludington, S.D., Maxwell, C.H., and Richter, D.H., 1986, Descriptive model of rhyolite-hosted Sn, in Cox, D.P., and Singer, D.A., eds., Mineral Deposit Models: U.S. Geological Survey Bulletin 1693, p. 168.

Reed, M.H., and Spycher, N.F., 1985, Boiling, cooling, and oxidation in epithermal systems: a numerical modeling approach, in Berger, B.R. and Bethke, P.M., editors: Geology and geochemistry of epithermal systems, Reviews in Economic Geology, v. 2, p. 249-272.

Reynolds, R.L., and Goldhaber, M.B., 1983, Iron disulfide minerals and the genesis of roll-type uranium deposits: Economic Geology, v. 78, p. 105-120. 
Romberger S.B., 1984, Transport and deposition of uranium in hydrothermal systems at temperatures up to $300^{\circ} \mathrm{C}$ - Geological implications, in De Vivo, B., Ippolito, F., Capaldi, G., Simpson, P.R., eds., Uranium geochemistry, mineralogy, geology, exploration and resources: London, England, The Institute of Mining and Metallurgy, p. 12-18.

Romberger, S.B., 1999, Mobility of uranium and thorium in natural aqueous systems: EOS, Transactions of American Geophysical Union, v. 80, no. 46, Supplement, p. 1204.

Roper, M.W., and Wallace, A.B., 1981, Geology of the Aurora uranium prospect, Malheur County, Oregon, in Goodell, P.C., and Waters, A.C. eds., Uranium in Volcanic and Volcaniclastic Rocks: American Association of Petroleum Geologists Studies in Geology, v. 13, pp. 81-88.

Rytuba, J.J., 1994, Evolution of volcanic and tectonic features in caldera settings and their importance in the localization of ore deposits: Economic Geology, v. 89, $1687-1696$.

Rytuba, J.J., and Conrad, W.K., 1981, Petrochemical characteristics of volcanic rocks associated with uranium deposits in the McDermitt caldera complex, in, Goodell, P.C., and Waters, A.C., eds., Uranium in Volcanic and Volcaniclastic Rocks: American Association of Petroleum Geologists Studies in Geology, v. 13, p. $63-$ 72 .

Rytuba, J.J., and Glanzman, R.K., 1979. Relation of mercury, uranium, and lithium deposits to the McDermitt caldera complex, Nevada-Oregon: Nevada Bureau of Mines and Geology, Report, no. 33, p. 109-117.

Rytuba, J.J., Glanzman, R.K., and Conrad, W.K., 1979, Uranium, thorium, and mercury distributions through the evolution of the McDermitt caldera complex, in Basin and Range Symposium, 1979: Denver, Rocky Mountain Association of Geologists, p. 405-413.

Schlepp, Lawrence, Landais, Patrick, Elie, Marcel, and Faure, Pierre, 2001, Influence of paleoenvironment and radiolytic alteration on the geochemistry of organic matter from Autunian shales of the Lodeve uranium deposit, France: Bulletin of the Geological Society of France, v. 172, p. 99-109.

Schoonen, M.A.A., and Barnes, H.L., 1991, Mechanisms of pyrite and marcasite formation from solution-III. Hydrothermal processes: Geochimica et Cosmochimica Acta, v. 55, p. 3491-3504.

Seedorff, Eric, Dilles, J.H., Proffett, J.M., Jr., Einaudi, M.T., Zurcher, L., Stavast, W.J.A., Johnson, D.A., and Barton, M.D., 2005, Porphyry deposits-Characteristics and 
origin of hypogene features, in Economic Geology $100^{\text {th }}$ Anniversary Volume, p. 251-298.

Seward, T.M., and Barnes, H.L., 1997, Metal transport by hydrothermal ore fluids, in Barnes, H.L., ed., Geochemistry of hydrothermal ore deposits ( $3 \mathrm{~d}$ ed.): New York, John Wiley and Sons, p. 435-486.

Shawe, D.R., Nash. J.T., and Chenoweth, W.L., 1991, Uranium and vanadium deposits, in Gluskoter, H.J., Rice, D.D., and Taylor, R.B., eds., Economic Geology, U.S.: Boulder, Colorado, Geological Society of America, The Geology of North America, v. P-2, p. 103-124.

Sheppard, R.A., and Hay, R.L., 2001, Formation of zeolites in open hydrologic systems, in D.L. Bish and D.W. Ming, eds., Natural Zeolites-Occurrence, Properties, Applications: Reviews in Mineralogy and Geochemistry, v. 45, p. 261-276.

Sherborne, J.E., Jr., Buckovic, W.A., Dewitt, D.B., Hellinger, T.S., and Pavlak, S.J., 1979, Major uranium discovery in volcaniclastic sediments, Basin and Range Province, Yavapai County, Arizona: American Association of Petroleum Geologists Bulletin, v. 63, p. 621-646.

Sillitoe, R.H., and Bonham, H.F., Jr., 1984, Volcanic landforms and ore deposits: Economic Geology, v. 79, p. 1286-1295.

Silver, L. T., 1976, A regional uranium anomaly in the Precambrian basement of the Colorado Plateau: Abstracts with Programs, Geological Society of America, v. 8, no. 6, p. 1107-1108.

Simmons, S.F., 1991, Hydrologic implications of alteration and fluid inclusions studies in the Fresnillo District-Evidence for a descending water table and a brine reservoir during formation of hydrothermal $\mathrm{Ag}-\mathrm{Pb}-\mathrm{Zn}$ deposits: Economic Geology, v. 86, p. 1579-1602.

Simmons, S.F., White, N.C., and John, D.A., 2005, Geological characteristics of epithermal precious and base metal deposits, in Economic Geology $100^{\text {th }}$ Anniversary Volume: Society of Economic Geologists, p. 485-522.

Simpson, P.R., and Hurdley, J., 1988, Granites as indicators of uranium provinces, in Recognition of Uranium Provinces: Vienna, International Atomic Energy Agency, IAEA-TC-450, p. 45-59.

Singer, D.A., 1993, Basic concepts in three-part quantitative assessments of undiscovered mineral resources: Nonrenewable Resources, v. 2, p. 69-81.

Singer, D.A., 2007, Estimating amounts of undiscovered resources, in Briskey, J.A., and Schulz, K.J., eds., Proceedings for a Workshop on Deposit Modeling, Mineral 
Resource Assessment, and Their Role in Sustainable Development: U.S. Geological Survey Circular 1294, p. 79-84.

Smith, R.C., and Sharp, J.M., Jr., 2006, The hydrology of tuffs, in Heiken, G., ed., Tuffs-Their Properties, Uses, Hydrology, and Resources: Geological Society of America Special Paper 408, p. 91-111.

Smith, R.L., and Bailey, R.A., 1968, Resurgent cauldrons: Geological Society of America Memoir, no. 116, p. 613-662.

Smith, S.M., 1997, National Geochemical Database - Reformatted data from the National Uranium Resource Evaluation (NURE) hydrogeochemical and stream sediment reconnaissance (HSSR) program: U.S. Geological Survey Open-File Report 970492,

Smith, S.M., and Smith, D.B., 2005, Development and utilization of a national geochemical database, in Programs and Abstracts, $22^{\text {nd }}$ International Geochemical Exploration Symposium: Perth, Western Australia, September 19232005 , p. 161.

Steven, T.A., Cunningham, C.G., and Machette, M.N., 1981, Integrated uranium systems in the Marysvale volcanic field, west-central Utah, in Goodell, P.C. and Waters, A.C., eds., Uranium in volcanic and volcaniclastic rocks: American Association of Petroleum Geologists, Studies in Geology, v.13, p. 111-122.

Stuckless, J.S., 1980, Interpretation of thorium to uranium rations in granitic rocks and implications for uranium exploration: American Association of Petroleum Geologists Bulletin, v. 64, p. 789-790.

Surdam, R.C., 1977, Zeolites in closed hydrologic systems, in Mineralogy and Geology of Natural Zeolites: Mineralogical Society of America Short Course Notes, v. 4, p. 65-92.

Sverjensky, D.A., 1987, The role of migrating oil field brines in the formation of sediment-hosted Cu-rich deposits: Economic Geology, v. 82, p. 1130-1141.

Taylor, H.P., 1997, Oxygen and hydrogen isotope relations in hydrothermal mineral deposits, in Barnes, H.L., ed., Geochemistry of Hydrothermal Ore Deposits (3d ed.): New York, John Wiley and Sons, p. 229-302.

Thompson, T.T., 1988, Geology and uranium-thorium deposits of the Bokan Mountain granite complex, southeastern Alaska: Ore Geology Reviews, v. 3, p. 193-210.

Turner-Peterson, C.E., 1985, Lacustrine humate model for primary uranium ore deposits, Grants uranium region, New Mexico: American Association of Petroleum Geologists Bulletin, v. 69, p. 1999-2020. 
U.S. Environmental Protection Agency, 2006, Uranium location database compilation: Washington, D.C., EPA-402-R-05-009, 24 p.

U.S. Geological Survey, 2007, Geologic assessment of undiscovered oil and gas resources of the Eastern Great Basin Province, Nevada, Utah, Idaho, and Arizona: U.S. Geological Survey, Digital Data Series Report DDS-0069 [CD-ROM].

Vigar, Andrew, and Jones, D.G, 2005, Technical report on the mining leases covering the Ben Lomond uranium-molybdenum deposit, Queensland, Australia: Technical report for Maple Minerals Corporation of Toronto, Canada, 57 p. [Available as a pdf from www.sedar.com/findcompanydocuments, then manual search for public companies, Mega Uranium Ltd, Technical Report May 9, 2005.]

Vikre, P.G. 1981, Silver mineralization in the Rochester District, Pershing County, Nevada: Economic Geology, v. 76, p. 580-609.

Vikre, P.G., 1987, Paleohydrology of Buckskin Mountain, National District, Nevada: Economic Geology, v. 82, p. 934-950.

Waber, N., Schorscher, H.D., and Peters, Tj., 1992, Hydrothermal and supergene uranium mineralization at the Osamu Utsumi Mine, Pocos de Caldas, Minas Gerais, Brazil: Journal of Geochemical Exploration, v. 45, p. 53-112.

Wallace, A.R., 2003, Geology of the Ivanhoe Hg-Au District, northern NevadaInfluence of Miocene volcanism, lakes, and active faulting on epithermal mineralization: Economic Geology, v. 98, p. 409-424.

Wallace, A.R., and Whelan, J. F, 1986, The Schwartzwalder uranium deposit, IIIAlteration, vein mineralization, light stable isotopes, and genesis of the deposit: Economic Geology, v. 81, p. 872-888.

Wallace, A.R, Ludington, Steve, Mihalasky, M.J., Peters, S.G., Theodore, T.G., Ponce, D.A., John, D.A., and Berger, B.R., 2004, Assessment of metallic mineral resources in the Humboldt River Basin, Northern Nevada: U.S. Geological Survey Bulletin 2218, 295 p. [CD-ROM].

Wallace, A.B., and Roper, M.W., 1981, Geology and uranium deposits along the northeastern margin, McDermitt Caldera Complex, Oregon, in, Goodell, P.C., and Waters, A.C., eds., Uranium in Volcanic and Volcaniclastic Rocks: American Association of Petroleum Geologists Studies in Geology, v.13, p. 73-79.

Ward, J.M., 1978, History and geology of Homestake's Pitch project, Saguache County, Colorado [abs.], in Program for the $107^{\text {th }}$ annual meeting, American Institute of Mining Metallurgical and Petroleum Engineers: Denver, Colorado, February 26March 2, 1978. 
Ward, S.H., 1981, Gamma-ray spectrometry in geologic mapping and uranium exploration, in Economic Geology Seventy-Fifth Anniversary Volume, p. 840 849.

Waters, A.C., and Granger, H.C., 1953, Volcanic debris in uraniferous sandstones and its possible bearing on the origin and precipitation of uranium: U.S. Geological Survey Circular 224, 24 p.

White, D.E, 1968, Hydrology, activity, and heat flow of the Steamboat Springs thermal system, Washoe County, Nevada: U.S. Geological Survey Professional Paper 458-C, $109 \mathrm{p}$.

Winograd, I.J., 1971, Hydrogeology of ash flow tuff — preliminary statement: Water Resources Research, v. 7, p. 994-1006.

Zielinski, R.A., 1978, Uranium abundances and distribution in associated glassy and crystalline rhyolites of the western United States: Geological Society of America Bulletin, v. 89, p. 409-414.

Zielinski, R.A., 1981, Experimental leaching of volcanic glass-Implications for evaluation of glassy volcanic rocks as sources of uranium, in Goodell, P.C., and Waters, A.C., eds., Uranium in Volcanic and Volcaniclastic Rocks: American Association of Petroleum Geologists Studies in Geology, v.13, p. 1-11.

Zielinski, R.A., 1982, Uraniferous opal, Virgin Valley, Nevada-Conditions of formation and implications for uranium exploration: Journal of Geochemical Exploration, $\mathrm{v}$. $16,197-216$.

Zielinski, R.A., 1985, Volcanic rocks as sources of uranium, in Uranium in Volcanic Rocks: Vienna, International Atomic Energy Agency, Tecpub-690, pp. 83-95.

Zielinski, R.A., Lindsey, D.A., and Rosholt, J.N., 1980, The distribution and mobility of uranium in glassy and zeolitized tuff, Keg Mountain area, Utah, USA: Chemical Geology, v. 29, p. 139-162. 


\section{Appendix: Grade-Tonnage Relations Among Volcanogenic Uranium Deposits}

Grade and tonnage data for known deposits of the volcanogenic U model (Bagby, 1986) describes 21 deposits (Mosier, 1986. For this review, I have attempted to confirm the grade and tonnage data for those 21 deposits and also to examine the geologic descriptions to determine if they fit the criteria discussed here. Geologic information for most of the deposits could be found in the literature, but data for several small deposits were not confirmed. The original data from Mosier (1986), and newer data compiled here, are in table 1-1; comments are included. The plots of grade and tonnage (figs. 1-1 and 1-2) are for 32 deposits described by new data (17) and old data (15) that seem to be most reliable. Figure 1-3 shows grade vs. tonnage for deposits discussed here and 47 deposits in the IAEA (2008) database. Note that tonnage figures refer to amount of contained uranium as $\mathrm{U}_{3} \mathrm{O}_{8}$, because these are the numbers generally reported in the literature. The USGS grade-tonnage models traditionally refer to amount of ore, generally as millions of tonnes.

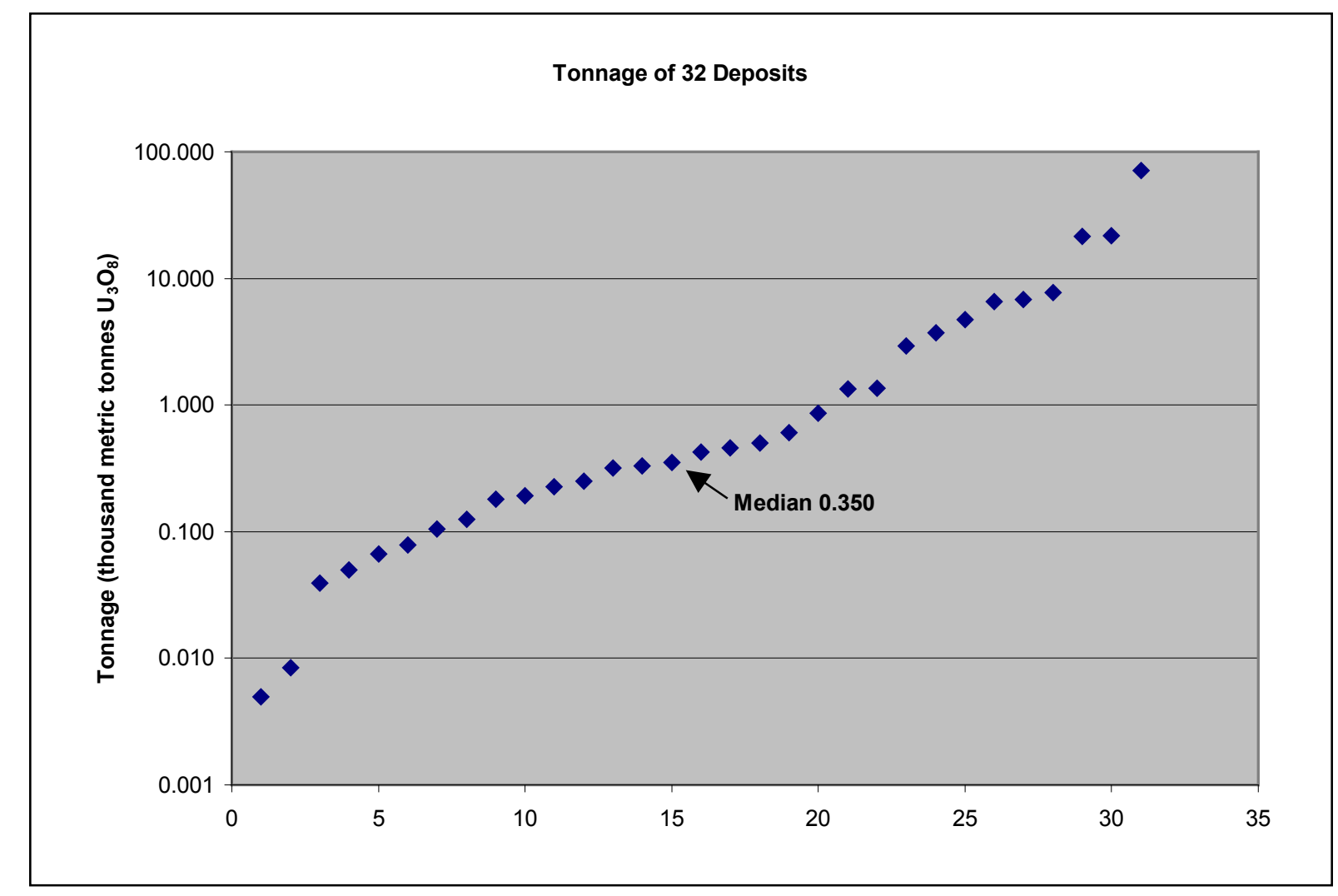

Appendix Figure 1-1. Tonnage of 32 volcanogenic uranium deposits. (Expressed in thousands of metric tonnes contained $\mathrm{U}_{3} \mathrm{O}_{8}$ ). 


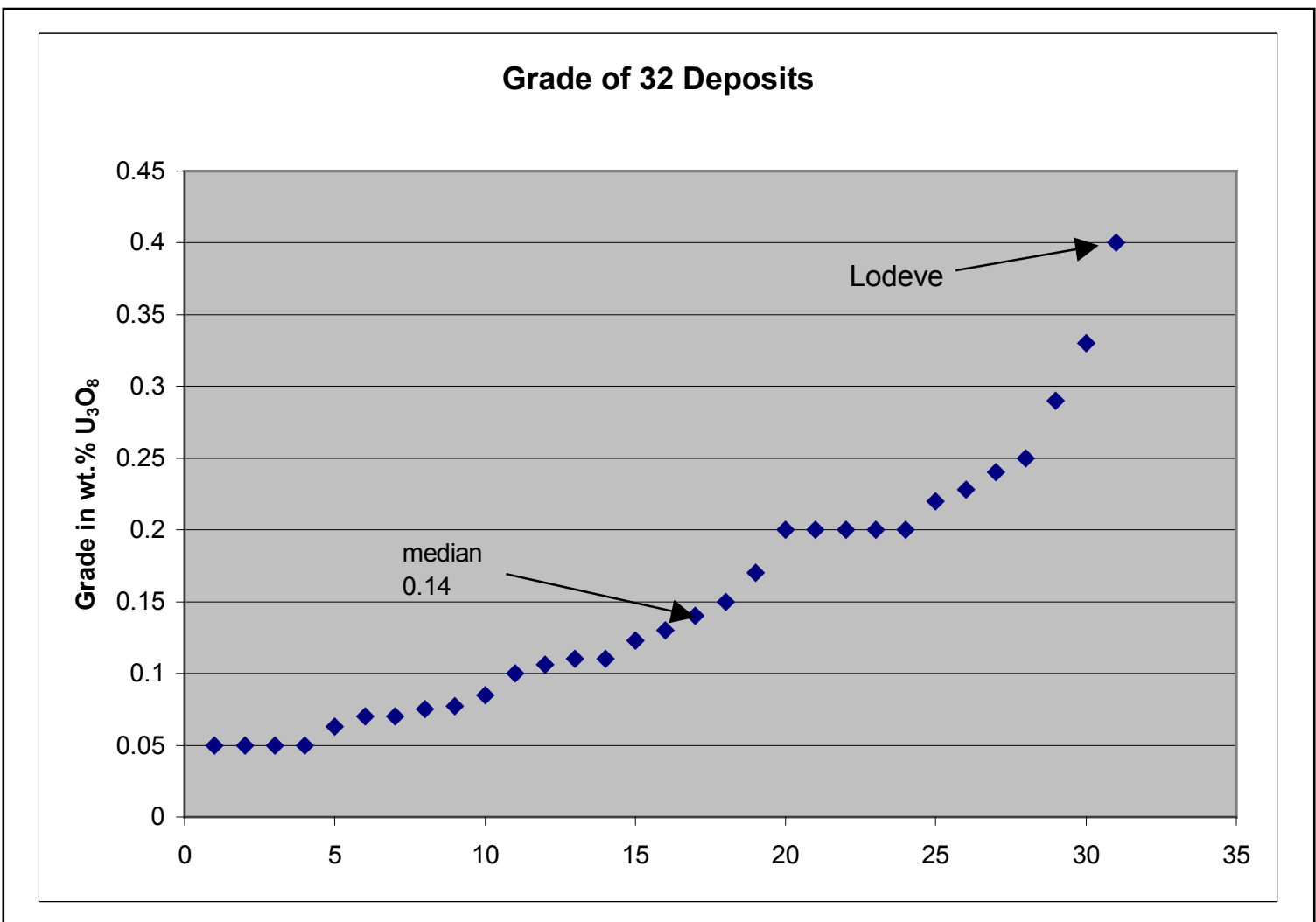

Appendix Figure 1-2. Grade of uranium in 32 volcanogenic deposits. The highest grade is for a deposit in the Lodeve District that is not typical. No distinction is made for style of mining or date of mining. 


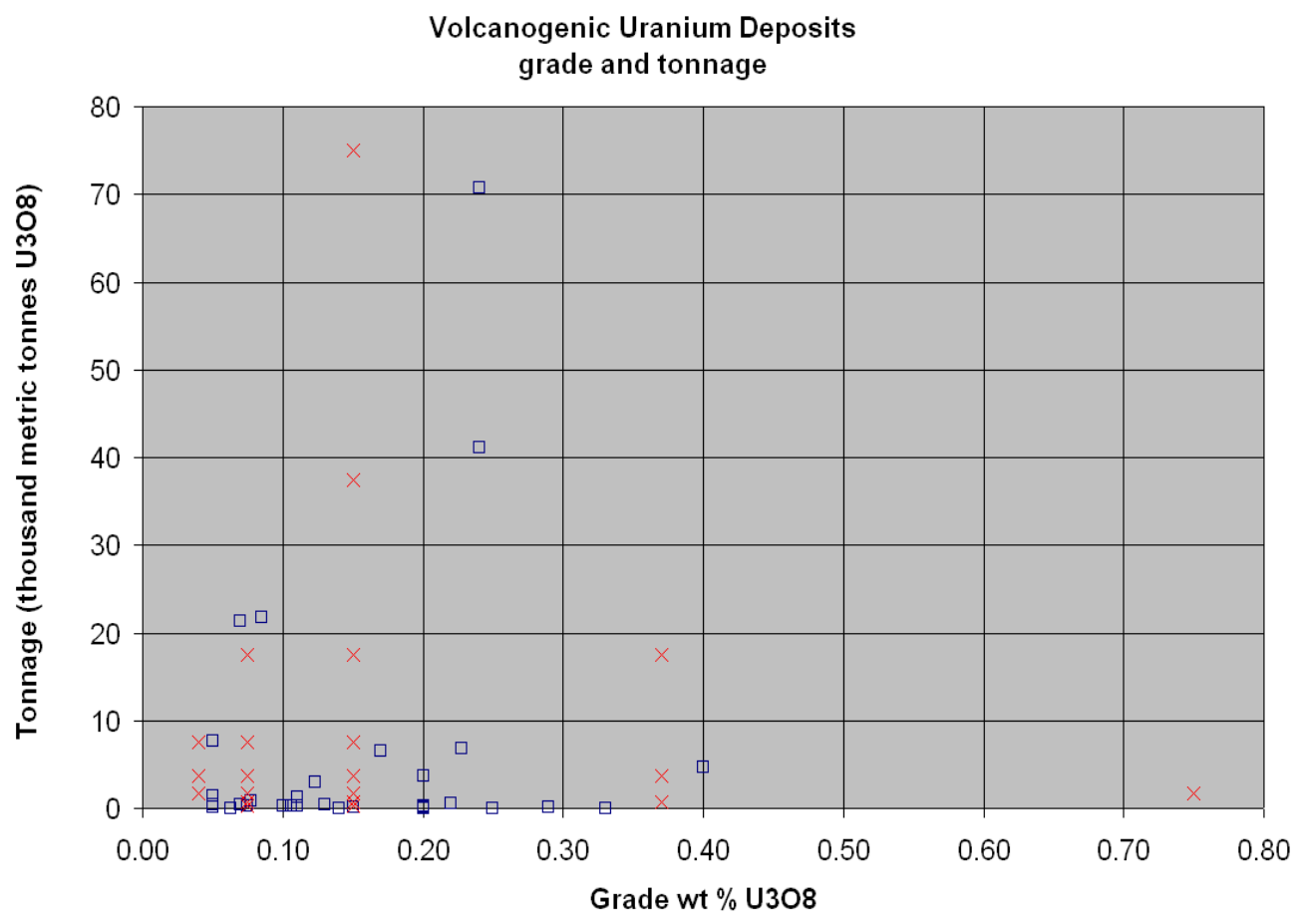

Appendix Figure 1-3. Grade and tonnage of volcanogenic uranium deposits. Data discussed in this report (table 1-1, 32 deposits) shown as squares. Data for 47 "volcanic" deposits from IAEA (2008) shown by X's. Darker symbols are for two or more deposits that overlap. The lone very high grade ( 0.75 percent), low tonnage deposit from Bulgaria probably represents a special mining situation.

The user of this dataset should be aware of possible confusion in units. For a variety of reasons, information on uranium is reported in about six ways. Uranium grades in the United States have long been reported by miners in pounds per short ton; a million pounds of production mark a major mine. Some reports use parts per million and others use weight percent. Reports are split between grades as the metal, $\mathrm{U}$, and the oxide, $\mathrm{U}_{3} \mathrm{O}_{8}$; some authors are not explicit on their units. The new standard seems to be weight percent $\mathrm{U}_{3} \mathrm{O}_{8}$, and I have attempted to accurately convert values to this system. The conversion factor from $\mathrm{U}$ to $\mathrm{U}_{3} \mathrm{O}_{8}$ is 1.1792 . The conversion from tons to tonnes is 0.9072. Good information on conversion factors can be found at www.wiseuranium.org/cunit.html. Note that Mosier (1986) reports tonnages of ore, not contained metal $\left(\mathrm{U}\right.$ or $\left.\mathrm{U}_{3} \mathrm{O}_{8}\right)$, thus those numbers are orders of magnitude larger than the numbers for contained metal reported here.

Inclusion of some deposits in this tabulation could be questioned; the easiest way to resolve this problem is to eliminate them from the dataset or g-t curve. The Pocos de 
Caldas (Osamu Utsumi) deposit is clearly a very large one and most believe it formed in several stages; some consider it a magmatic deposit (Cuney and Kyser, 2009). I have questioned the inclusion of metamorphosed volcanic deposits; there may not be a problem if the metamorphic stage did not significantly change the grade or tonnage from the syn-volcanic stage. Quite possibly it did not in the case of Michelin (Gandhi, 1978). Other deposits, such as Novazza, may have been created by a metamorphic process and thus should belong to a different deposit model.

There are other factors that users might want to keep in mind when using this data. This compilation obviously mixes past production and resources calculated from drill holes; it also mixes production or resource models for open pit and underground mining. Date of mining also is a factor; the uranium mining in the United States from 1946 to about 1963 was done on government contracts which often included subsidies that allowed mining of small deposits that otherwise would not have been mined. Technological changes have generally encouraged mining of lower grade uranium deposits, but this is not a simple assumption when the increased costs of permitting and reclamation are added in recent years. Some deposits, like White King in Oregon and Midnite Mine, Washington, have gone from "good producer" to "Superfund site," a designation that presumably negates any chances of future mining of resources in the ground. Thus, the data in table 1-1 are not as simple as they might seem.

Some additional generalizations can be offered for the tonnage trends in figure 11 and table 1-1, specifically for deposits in the U.S. 1) All of the deposits shown as having less than about $1,000 \mathrm{t}$ of $\mathrm{U}_{3} \mathrm{O}_{8}$ were mined prior to 1982 and do not include an estimate of unmined resource. In some cases the lack of resource information reflects lack of definitive drilling after about 1975 and in other cases it is a matter of policy to keep the resource information confidential. 2) Of the important deposits $(>1,000 \mathrm{t})$, only the Midnite and Pitch deposits were mined extensively, but for those deposits the resource number does not include a reliable estimate of the resource that remains in the ground. 3) The reports of resources $>1,000 \mathrm{t}$ in several unmined deposits appear to be reliable, but the resources are in various categories (reserves, inferred resources, etc) that can not be evaluated here.

Trends in data for uranium grades (table 1-1) are difficult to summarize. Many of the higher grades, greater than about 0.2 percent $\mathrm{U}_{3} \mathrm{O}_{8}$, were mined underground during a time of government contracts. Many of the grades of about 0.05 to 0.1 percent $\mathrm{U}_{3} \mathrm{O}_{8}$ were calculated at about 1980 when the value of $U$ was relatively high and open-pit (bulk) mining seemed most favorable. However, geologic associations suggest that in some situations (Date Creek, Pena Blanca) the lower grades of 0.1 percent $\mathrm{U}_{3} \mathrm{O}_{8}$ or less are characteristic of the environment, not the style of mining or economic model. 
Table 1-1. Grade and tonnage for 32 volcanogenic deposits described in this report. See also figures 1-1, 1-2, and 1-3.

[Reference abbreviations: C, Chenoweth, 1991; M, Mosier, 1986; N, Nash, this report]

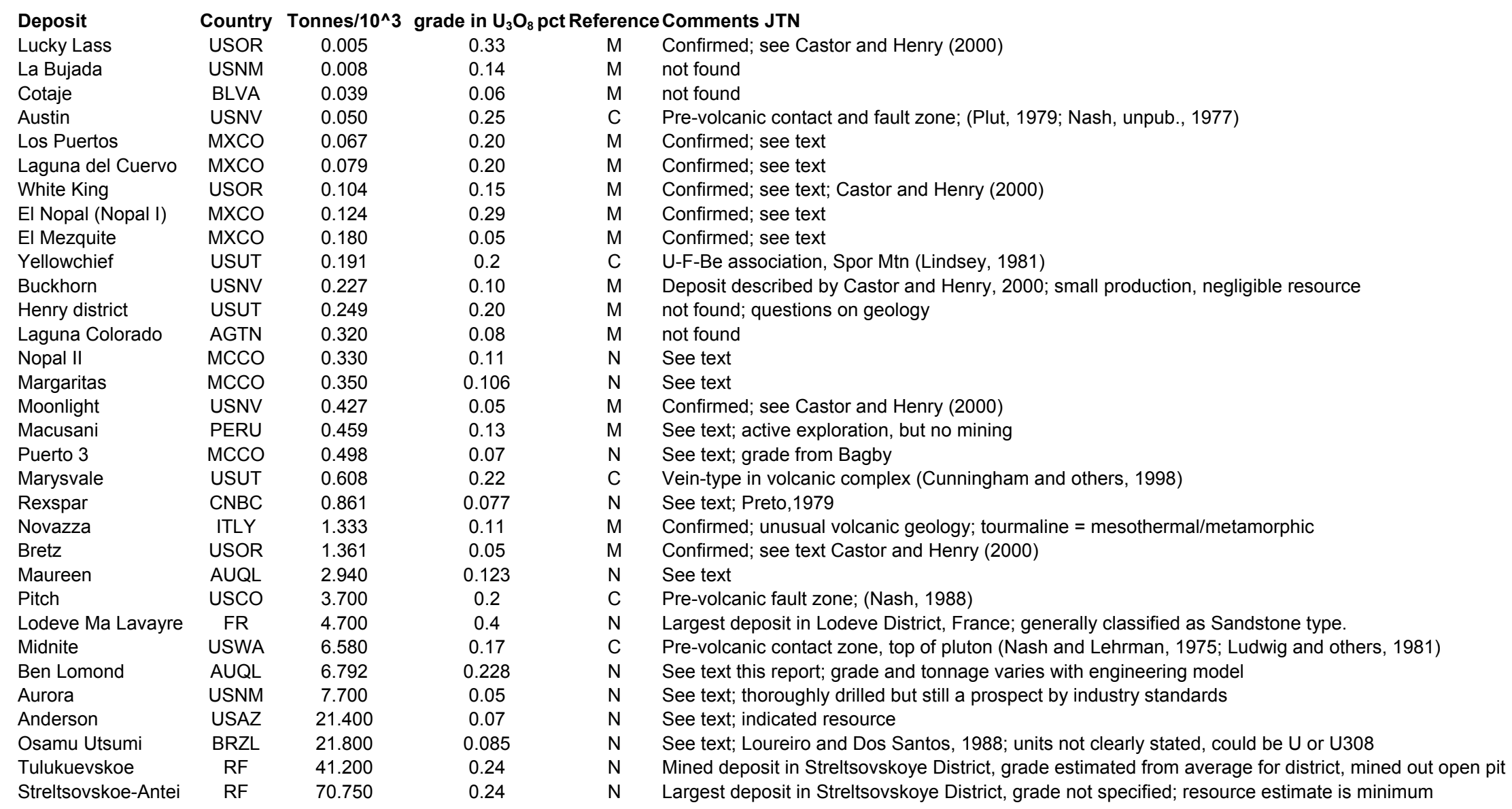

